Portland State University

PDXScholar

8-1975

\title{
House Bill 1302 : An Armistice in the Fish War on the Columbia
}

Emery Lewellyn Albertson
Portland State University

Follow this and additional works at: https://pdxscholar.library.pdx.edu/open_access_etds

Part of the American Politics Commons, Other Political Science Commons, and the Political History Commons

Let us know how access to this document benefits you.

\section{Recommended Citation}

Albertson, Emery Lewellyn, "House Bill 1302 : An Armistice in the Fish War on the Columbia" (1975). Dissertations and Theses. Paper 2268.

https://doi.org/10.15760/etd.2265

This Thesis is brought to you for free and open access. It has been accepted for inclusion in Dissertations and Theses by an authorized administrator of PDXScholar. Please contact us if we can make this document more accessible: pdxscholar@pdx.edu. 
AN ABSTRACT OF THE THESIS OF Emery Lewellyn Albertson for the Master of Arts in Political Sclence presented August 8, 1975.

Title: HOUSE BILL 1302: AN ARMISTICE IN THE FISH WAR ON THE COLUMBIA APPROVED BY MEMBERS OF THE THESIS COMMITTEE:

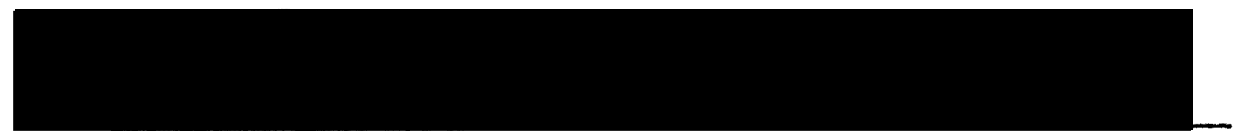

Ronald C. Cease, Chairman

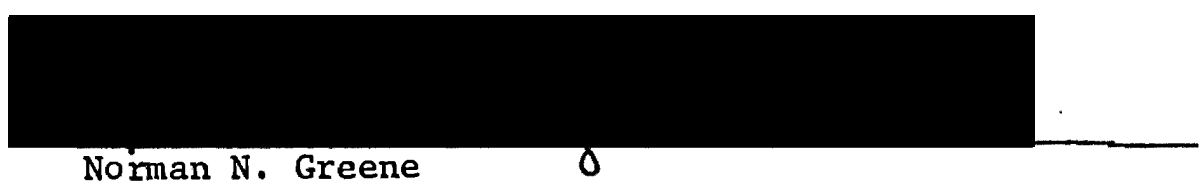

Norman N. Greene

0

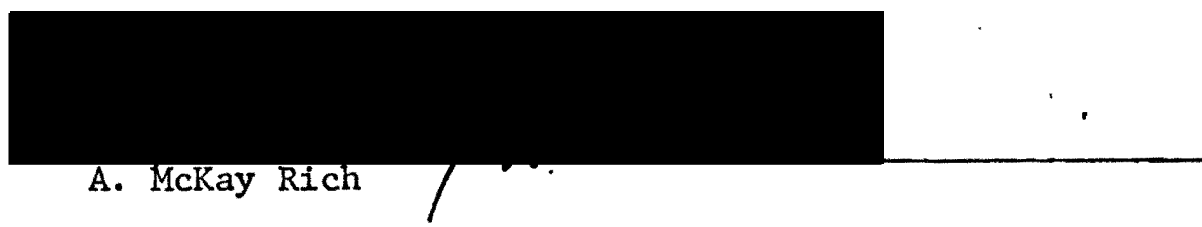

In late Spring of 1969, shortly before the Oregon Legislative Session adjourned, House Bill No. 1302 as amended passed the last legislative hurdle and was signed by the Governor. The new statute recognized steelhead trout as a game fish and provided for an incidental catch of these fish by the commercial fishery.

HB 1302 was a turning point in a century of conflict over anadromous fish of the Columbia River. The bill served as an armistice in a long sports-commercial steelhead conflict by providing some protection for these fish from commercial fishing. However the bill held off a major shift in the sports-commercial balance of power for only five years. The "final" victory went to the sports fishermen in 1974--the voters approved Ballot Measure No. 15 which banned steelhead from sale. 
Although the sportsmen finally won the steelhead battle, they may have lost the war. Unless the erosion of fish runs caused primarily by dams is checked the fishery may disappear.

Chapter I gives an overview of $\mathrm{HB} 1302$ and discusses the significance of the Columbia River anadromous fishery to Oregon. Chapter II is a history of the Columbia River fishery and traces the conflict between the various fishing interest groups. Chapter III details the causes of the conflict and describes the relattonship between dams and declining runs of fish. Chapter IV discusses the Legislative passage of HB 1302 . Chapter V discusses lobbying and pressure group activities concerning HB 1302. Chapter VI chronicles events subsequent to passage of HB 1302 . Chapter VII contains summary and concluding remarks. 
HOUSE BILL 1302: AN ARMISTICE

IN THE FISH WAR ON THE COLUMBIA

BY
EMERY LEWELLYN ALBERTSON

A thesis submitted in partial fulfillment of the requirements for the degree of

MASTER OF ARTS
in
POLITICAL SCIENCE

Portland State University

1975 


\section{TO THE OFFICE OF GRADUATE STUDIES AND RESEARCH:}

The members of the Committee approve the thesis of

Emexy Lewellyn Albertson presented August 8, 1975.

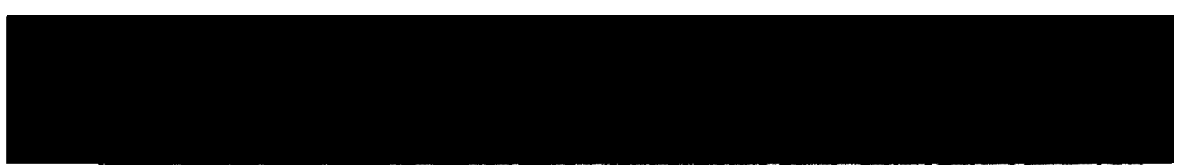

Ronald C. Cease, Chairman

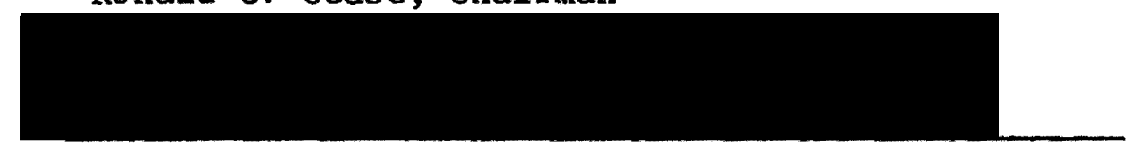

Norman N. Greene

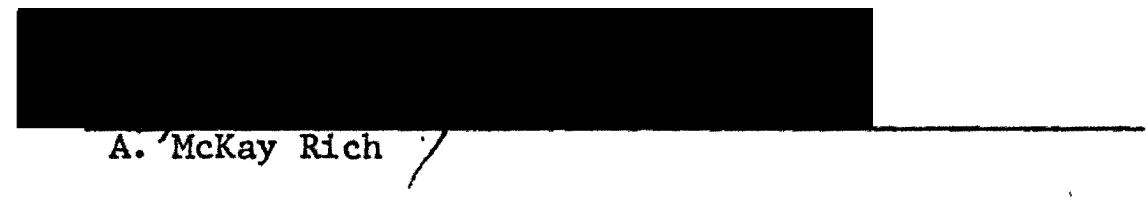

APPROVED:

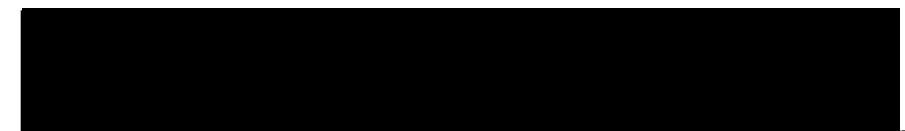

Norman No Greene, Head, Bepartment of Political Science

Dávid T. Clark, Dean of Graduate Studies and Research 


\section{ACKNOWLEDGEMENTS}

I wish to thank those who gave special help with effort, advice and assistance: My mother, Minnie Albertsan, and friends, Judy Pingo, Bernard and Pauline Kurtz. 


\section{PREFACE}

The research and development of this thesis began in the summer of 1969 and ended in the spring of 1975. So current developments occurring in the 1975 Leglslative Session have not been included. One notew or thy event took place after strife of many years - the regulation of Oregon's fisheries (both sports and commercial) as well.as all game resources were placed under the control of a single agency. Senate Bill No. 613 combined the two independent Fish and Wildlife Commissions into a new consolidated Fish and Wildlife Commission.*

This development further illustrates the shift of power in favor of game angling. Shortly after WWI game fish proponents were able to separate the then consolidated body in charge of both fish and game. The Fish and Game Commissions of Oregon were areated. Sport fishing proponents actively sought separation of fish and game matters because they considered game fishing to be dominated by commercial fishing.

By 1973 the situation had reversed enough for sports interests to be pushing for a consolidation of the two commissions. However, the commercial industry actively and successfully fought the merger bill HB 2652. By 1974 they had lost the steelhead war to Ballot Measure No. 15. In the 1975 Session of the legislature the commerclal Jobby did not oppose the merger.

\footnotetext{
* 1975 Legislature Considered More Than 2,500 Bills," Oregonian,
} 15 June, 1975, Sect. 1, p. 17, cols. 1-7. 
TABLE OF CONTENTS

PAGE

ACKNOWLEDGMENTS ..................

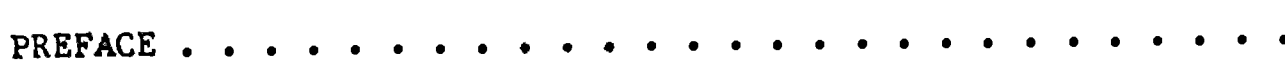
1v

LIST OF TABLES

$\mathbf{v 1}$

LIST OF FIGURES

vi1i

\section{CHAPTER}

I INTRODUCTION ................... 1

II HISTORY OF ANADROMOUS FISHING . . . . . . . . . 8

First Period: Backgrounds . . . . . . . 9

Intermediate Period: Rise of Trade and Barter

System . . . . . . . . . . . . .

Third Period: Industry at Its Peak--Gear and

Game Quarrels Appear . . . . . . . . .

Fourth Period: Sport, Gillnet, and Indian

Fishing . . . . . . . . . . . . . .

III THE WHY OF THE CONFLICT . . . . . . . . . .

Decline of the Resource . . . . . . . .

The Role of Dams . . . . . . . . . .

Commercial Interest in the Resource . . . .

Growth of the Sport Fiṣhery . . . . . .

Psychology of the Conflict . . . . . . . 50

IV PASSAGE OF HB 1302 . . . . . . . . . . 55

Prior to the Hearing ............ 55

The Committee Hearing ........... 57

Proposed Game Commission Amendments ..... 65

Position Statements--Heard and Bugas ..... 68 
The First Vote--April 10, 1969 ........ 78

- The Interim Committee . . . . . . . 80

The Surprise Move . ... . . . . . . 84

Passage of the Bill ............ . . 91

V WHY THE BILL PASSED . . . . . . . . . . . . 92

Lobbying Relationships . . . . . . . . 92

Lobbying the "Swing" Member ......... . 99

Political Styles............... 109

Executive Influence ............. 110

Access to the Committee Chairman . . . . . 110

Strategy and Tactics of the Major Interests .. 113

Politics of the Real and the Ideal . . . . . 121

How the Groups View the Bill . . . . . . . 122

Accomplishments . . . . . . . . . . 125

VI EVENTS (1969-1974)................. 126

The First Five Years . . . . . . . . 126

The 1973 Session . . . . . . . . . . 128

Recent Trends ............... 129

The Indians Win in Court ........... 132

VII SUMMARY AND CONCLUSION . . . . . . . . . . 135

BIBLIOGRAPHY . . . . . . . . . . . . 141 


$$
\text { LIST OF: TABLES }
$$

TABLE

\section{PAGE}

I Escapement and Return per Spawner............. 36

II Salmon and Steelhead Counts................. 41

III Value of Columbia River Canned Salmon Pack........ 44

IV Summer Steelhead Entering Columbia River........ 47

$\mathrm{V}$ Numbers of Winter Steelhead (In Thousands)

Columbia River System, 1953-54 - 1970-71.... 52 


\section{LIST OF FIGURES}

FIGURE

PAGE

1. Columbia-Snake Inland Waterway

2. Columbia River Winter Season Chinook and Steelhead Landings, January-March 7, 1938-70.

3. Annual Catches of Winter Steelhead by Commercial

Fishermen and Anglers from the Columbia River

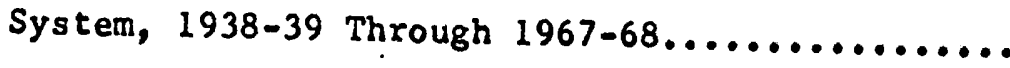


CHAPTER I

\section{INTRODUCTION}

A significant legislative step in a century of conflict over the use of Columbla River anadromous' flsh species occurred on May 6, 1969. On that day the Orogon House of Representatives passed House Bill No. 1302. The Senate voted approval on June 6. Governor Tom McCall signed the bill shortly thereafter and it went into effect on August $22,1969 .^{2}$ House Bill No. 1302 (codified starting at 0.R.S. 506.016, but referred to herein as $\mathrm{HB} 1302)^{3}$ recognized ste日lhead as a game fish. However, the bill also provided for an incidental catch of steelhead trout by the commercial fishing industry. Consequently, steelhead could still be caught commercially as they intermingled with salmon. 4

Although sport fishermen and conservationists had dreamed and labored for years to legally designate steelhead, an ocean-going trout, as a game fish, they expressed no elation over the passage of $\mathrm{HB} 1302$.

${ }^{1}$ Of fishes, as the salmon, going from the sea up river to spawn. Funk and Wagnalis. Standard Dictionary (New York: Harcourt Brace \& World, 1968), p. 52 .

2 Journals and Calendars of the Senate and House of the Fiftyfifth Legislative Assembly, Regular Session Beginning January 13 and ending May 23, 1969 (Salem: 1969), p. 719.

${ }^{3}$ Oregon Laws and Resolutions Enacted and Adopted by the Regular Session of the Fifty-fifth Legislative Assembly Beginning January 13 and Ending Mar 23,1960 (Salem: 1969), p. 758.

4Te law remained unchanged until November 5, 1974, when Ballot Measure 15 passed. Steelhead were then banned from sale--any incidentally caught steelhead became property of the State of Oregon. "How Oregon Cast its Ballot," Oregonian, 6 Nov. 1974, p. 1., col. 3. . 
On the other hand, the fish packing industry and many commercial fishermen who had fought the sport fish proponents for years were uncharacteristically pleased with the passage of HB 1302 .

The reason for these atypical reactions lay in the nature of the new law (as will be more fully explained in subsequent chapters). This new decree was to sport fishermen the least acceptable amendment of a formerly promising sport fishing proposal, HB 1302 as introduced. By the end of the 1969 legislative session, $\mathrm{HB} 1302$ had become a qualified victory for the commercial fishing industry.

Labeling steelhead as a game fish was a late development in the shifts of the balence of power hetween groups fishing on the Columbia. For the past 100 years, interest groun competition has gone through periods of fierce conflict followed by periods of calm. Moreover. during this period the influence of the various interest erouds has increased and declined.

No doubt, the outcome of these clashes was not always clear. to participants or observers. However, a general trend is clear. Fishing grouns capable of larger catches of fish have consistently generated hostility from other more "modest-catch" fishermen. 4lso. fishermen who take less at a time have been more numerous than "mass-catch" fishing interests. The more numerous fishermen have genorally banded together and have slowly driven the "mass-catch" fisherman from the river. These more modest-catch fishermen (currently the sport fishing interest grouns) have historically attemoted to realize their claim for more fish by gaining influence through state leigislation or from the generel public through the use of initiative petitions. 
interests as it generally was from the 1920's until 1969. The passage of SB 409 and the approval by the voters in the following year (November 4, 1974) of Ballot Measure No. 15, banning steelhead from sale 1llustrates the coming of political prominence to sport fishing interests.

Recently, another active interest group has also won more access to the fish on the Columbia. The Treaty Indians have gained favorable decisions in federal courts. Their first real success occurred in 1969. Until 1965 the Indians were generally in the background of the fish conflict. By 1965 Treaty Indian tribes were steadily increasing their catches of salmon. Beginning in. January of 1966, the State of Oregon responded with a vigorous policy of enforcement of state laws limiting fishing. 7 Several arrests were made before the courts clarified Tribal Treaty fishing rights in $1969 .^{8}$ In that year Federal District Judge Robert Belloni ruled that the State of Oregon must recognize a distinct interest in addition to sport and commercial fishing-the Treaty Indians? Since 1969 the Indians have won the right to increased catches of fish. By February of 1974 a decision favorable to the Indians was made in the State of Washington. District Judge George Boldt ruled that Treaty Indians fishing off their reservations-on their traditional fishing grounds-could catch up to 50 per cent of the allowable catch after

7 Jerry Tippens, "Commission Ready to Crack Down on Indians who Vi olate State Fishing Laws", Oregon Journal, 6 Jan. 1966,p. 3, cols. 1-8.

8 "Indians on Warpath to Preserve Fishing", Oregonian, 31 Jul. 1966, Sec. M, p. 9, cols. 1-2.

9James Magner, "Judge Rules in Favor of 1855 Indian Fishing Treaty," Oregotian, 25 Apr. 1969, p. 19, cols. 4-8. 
escapement for conservation of the runs. 10 This decision in turn hed an effect on Oregon's treatment of Treaty Indian fishing. In May of 1974, Jndge Belloni followed the Boldt precedent and authorized the Indians to take up to 50 per cent of the spring chinook salmon run in Oregon. The Fish Commission interpreted the decision as applying to the fall chinook salmon as well. 11

The increase in access to the resource by both sports fishermen and Tndians was accompanied by conflict. The Indians were compelled to go to the courts in Oregon and Washington and the sportsmen to the legislature and the voters. When $H B$ 1302. Was passed by the Legislature in 1969, many legislators hoped the bill would solve sport-commercial conflicts. Both the bill's sponsor, Representative Connie McCready, and the Chairman of the House Fish and Game Committee, Representative Rod McKenzie, expressed this hope:

Representative McCready...House Bill 1302 was introduced by me early in February in the hope of ending a long bitter user conflict on the Columbia...12.

Chairman McKenzia....it is said that this is nothing [sic] bill. The world cares less what we say here but I think that this is a historic day in Oregon-- in a hundred and some years this is the first time we got right down to

10 Feorge Dysart, Assistant Regional Solicitor, Department of the Interior. interviow held at Bonneville Power Building, Portland, Oregon, Sept. 1, 1974.

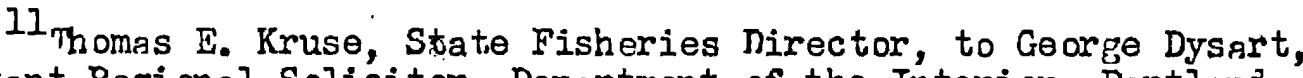
Assistant Regional Solicitor, Department of the Interior, Portland. Aug. 7, 1974. Pers onal Files of George Dysart, Portland, Oregon.

12. "House FI oor Debates" Tape Recording Number 18, RSI6, 72 A-93. 55th Session. 1969. State Archives, Salem, Mregan. n.d. 
cases and stated flatly that steelhead is a game fish ...13

When HB 1302 is considered in a realistic frame of reference--the course of events before and after passage of the bill-it is an important part of a seemingly endless series of fights over fish. The use of Columbia River anadromous fish have reoccurringly been a volatile issue. However, the roots of the conflict extend somewhat bevond varinus groun auarrels over these fish. The controversy springs as well from two outstanding values of the Columbia River. One of these is fishing-- the world's largest crop of chinook salmon. 14 The other is water power. At least one third of the hydroelectric potential of the United States is available from the Columbis. 15

The fish war on the Columbia in recent years has been a four-way struggle: between recreational fishing, commercial fishing, Tñdian treaty fishing and bydroelectric developments. However, the influence of dam building is undeniably a pervasive part of this struggle. The far reaching effects to the environment of hyoroelectric developments overshadow all fishing groups combined. These changes to the Columbia from federal power projects damage the fish mus. Paradoxically, open conflict, is between the sport and commercial anadromous fishing groups, while the real damage to the fish comes from dams. These mammoth con-

\section{Ibid.}

14Washington Department of Fisheries. Salmm Fisheries of the North Pacific Ocean No. 2 (Olympia, 1959),p. 23.

\footnotetext{
15 Banneville Power Administration, The Columbia River (Portland, 1964), p. 1 .
} 
crete reservoirs affect all utilizations of fish. The effect of less fish due to dems aggravates the clash between fishermen. With fewer fish, those remaining have become more valuable. Consequently there is a very intense open rivalry between fishing groups and a hidden conflict between demand for fish and dams on the Columbia River. The predominent feature of this controversy over the use of anadromous fish is the perennial nature of the fight between fishing groups and the general ignoring of the loss of fish due to dems. 


\section{HISTORY OF ANADROMOUS FISHING}

Historically, steelhead trout (Salmo gairdneri) from the Columbia River were caught and processed with salman. I Consequently they were considered as part of the Columbia salmon fishery, the record of which can be easily divided into four major historical divisions. The first period precedes the coming of Caucasian settlers to the Columbia River Basin. At that time there was a well developed Indian food fishery. Second, an intermediate period (1820-1865) developed. During this time, white treders bargained with the Indians of the Columbia Basin for fish, or took salmon from the river on their own initiative. They utilized the salmon in the local territory, attempted to preserve them with salt, and exported them. Third, there was a phase of intensive exploitation which began with the salmon canning industry. ${ }^{2}$

The fourth and current phase is a rather intensive use of the resource for sport fishing, as well as for commercial fishing. The demand for game fish is still intensifying, as is the need for more fish for commercial fishing and Indian treaty fishing.

In 1974 steelhead were barred from commercial sale by Ballot Measure 15. This is the first time in the history of the Columbia Basin they have been banned from sale. "How Oregon Cast Its Ballot", Oregonian, 6 Nov. 1974, p. 1., col. 3.

2United States Department of The Interior; The History and Development of The Fisheries of The Columbia River (Washington D. C.: G. P. 0., 1940), Bulletin No. 32., P. 139. 
FIRST PERIOD: BACKGROUNDS

The aboriginal inhabitants of the Columbia Besin were dependent on the gigantic runs of chinook salmon for their main source of food. Prior to the coming of Lewis and Clark, historians estimate the Indians' food fish production at 18,000,000 pounds annually. 3 To obtain this remarkable catch of fish, the natives used a highly developed array of fishing gear, including dip nets, spears, haul seines (a vertical net enclosing fish as the ends were brought together), and baskets and weirs (fences or enclosures of brush wood). The Indians also had canoes of hollowed out logs. Some of these vessels were large enough to carry from twenty to thirty persons, or eight to ten thousand pounds. 4

In 1792 the Columbia River was discovered by the Yankee skipper Robert Gray. He initiated trade with Columbia Tribal Indians, and among the first items bartered was salmon. Captain Gray exchanged at the rate of one nail for two fish; ${ }^{5}$ thus the salmon trade was inaugurated.

When Lewis and Clark arrived. on the river in the fall of 1805 , they found a great deal of activity related to salmon fishing, making frequent comments in their journals about the numerous racks for drying salmon. This dried fish was pulverized and became "pemmican". At one lodge, the expedition leaders noted a great quantity of bags filled with pemmican. They estimated that approximately sixty thousand pounds of

Ibid., p. 42 .

4 Ibid., pp. 142-147.

5 oregon Fish Comission, Biennial Report to the Governor and the Fifty-fifth Legislative Assembly (Salem: State of Oregon, 1968), p. 6. 
fresh fish were needed to fill these sacks. 6

The economy and pattern of life of these indigenous people were linked intimately with the silvery hoards of salmon. Fach time these creatures ascended the river to spawn, the natives took advantage of the ocourrence. For the Indian tribes of the Columbia Basin, salmon were both the staff of Iife and logal tender. Salmon was a principal medium of food and exchange with other tribes, including Indians from the plains east of the Rocky Mountains. This copious supply of fish supported a population of roughly fifty thousand Indiens at the beginning of the nineteenth century.7

As the settlers came into the Columbia Basin the Indians suffered greatly from a series of epidemic diseases. Historians estimated fourfifths of the basin inhabitants were decimated in a single summer season. Fishing diminished accordingly. The decline continued until the 1870's. At that time the commercial take increased enough to compare favorably with the amount formerly taken by tribal fishermen. 8

\section{INTERMEDIATE PERIOD: RISE OF TRADE AND BARTER SYSTEM}

As the first traders and settlers penetrated the Columbia Basin, they began to take salmon for their own use. By 1829 the first export

6 Dept. of Interior, History and Development Fisheries of The Columbia, 1940, op. cit., p. 140 .

7 Ibid., pp. 140-141.

${ }^{8}$ Bureau of Commercial Fisheries, Gommercial Fisheries of the Columbia River and Adjacent Ocezn Waters (Seattlo: G.P.O, n. d.) p. 22 (FIR Reprint 42 from Fishery Industrial Research, vol. 3, no. 3, Bureau of Commercial Flsberles). 
operation took place and by 1846 salted chinook salmon were a recognized object of trade in many parts of the world. However, the amount of anadromous fish used by the now industry, in local consumption and by Indians did not approach the total fish formerly taken by the Indians. ConsequentIy, there was less fishing pressure on the salmon runs during the 1820's to 1860's than at any other time in the history of the water course. 9

As the pianeers pushed further into the basin the valuable faod fishery became a crucial issue, so by the later 1840's political steps were being taken by pioneer leaders to protect this vital resource.

In 1848, the constitition [sic] of the territory contained a section demanding that streams in the territory in which salmon are found or to which they resort shall not be obstructed by dams or otherwise, unless such dams or obstructions are so constructed as to allow salmon to pass freely up and down.

But as is often the case, there is not always the means to enforce the edicts of the lawmakers. It is said that by 1900 there were at least 200 unladdered dams on tributacies in the Columbia River system. These were not all in Oregion, to be sure, but they all helped grind away at the Columbia River anadromous fish runs.

This early anxiety about the effects on the fish frgm dams was destined to grow and become a perennial concern. 10

Another issue at this time was the proper way to open the area to peaceful settlement by non-Indians. The U. S. Congress directed that treaties be negotiated with Indians for their lands. In 1855 negotia-

9Dept. of Interior, History and Development Fisheries of The Columbia, 1940, op. cit., pp. 142-150.

10Fish Commission, Biennial Report, 1968, p. 6. 
tions began. The Indians were reluctant to sign the treaties until they were persuaded by assurances that exclusive rights of taking fish in all streams running through or bordering on reservations belonged to them. They were granted the additional right to take fish at "all usual and accustomed places, in common with citizens of the Territory."I

As the pioneers continued to arrive, the economy erew. By 1861,. the salmon trade took on the aspects of a major industry. As a result of the steady growth of the salt salmon industry, commercial canning of salmon was introduced into Oregon as early as 1866. In that year four thousand cases of fourty-eight cans were packed, but concomitantly with the flourishing of this new business came the decline of salt salmon. THIRD PERIOD: INDUSTRY AT ITS PEAK - GEAR AND GAME QUARRELS APPEAR By 1873 Oregon had eight salmon canneries, and within ten years tbere were thirty-nine. The largest annual increase of the number of canneries occurred between 1876 and 1877, when they expanded from seventeen to a total of twenty-nine. The greatest number of canneries operated from 1883 to 1887, with thirty-nine canneries in operation at the peak. This rapid growth of canneries was the natural result of the advent of a now industry with a large supply of necessary raw materials at hand, and the price for the finished product was high, businesses

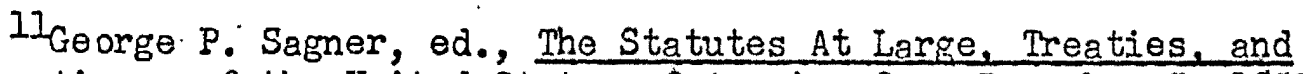
Proclamations, of the United States of America from December 5, 1859 To March 3.1863 (Boston: Little Brown and Company, 1863), XII p. 952-96.3 (12 stat. 951-957); reprinted., Buffalo, N. Y.: Dennis and Co., 1961) p. 952-953. 
were able to produce a quick profit for only a moderate investment. 12

Several factors caused the decline in the number of canneries:

(1.) The large increase in canneries brought an abundance of canned salmon. (2.) The heavy production drove the price of the finished product down. (3.) Canners were forced to compete for the flsh. This rivalry far salmon brought a sharp increase in the price paid to the commercial fishermen, increasing from twenty-five cents per fish in 1878 to fifty cents in 1879. By 1882 the price had risen to seventy-five cents and stabilized at that price for some time. 13

A rocord high of spring chinook salmon was caught in 1883-42,799,200 pounds. ${ }^{14}$ However, by 1899 the catch had dropped sharply to. 18,135,396 pounds. In the years from 1876 to 1886, with the exception of 1877, the yearly pack totaled $30,000,000$ pounds of more. 15 Thus in 1880 when more than $30,000,000$ pounds of fish were caught the state's population was $174,768,16$ or the equivalent of more than 161 pounds. per state sesident. By 1970, the year after passage of HB 1302 the compar-

12 Dept. of Interior, History and Development Fisheries of The Columbia, 1940. pp. 141-150.

13 Tbid., p. 151.

${ }^{1^{4}}$ Ibid., p. 151 .

15In 1877, only $25,840,000$ pounds of chinook were caught. Ibia.

16 United States Department of Commerce, Historical Statistics of the United States Colonial Times to 1957 (Washington, D. G., G. P. O., 1960) p. 12 . 
able figures were $1,502,300$ pounds 17 and $2,091,385^{18}$ or less than one pound of chinook per state resident.

The decline of the once great runs of fish was no accident but the result of the rapid expansion of the canning industry and the high prices paid to commercial fishermen. During this period the fishermen noticed that the once seemingly endless runs of chinook were shrinking. Also the commercial fishing interests began to express their first fears of a shortage of fish. The scarcity of fish heightened conflicts between those who fished. The clashes were between the operators of the various commercial fishing gear--particularly between those in direct competition on the same fishing grounds. Long before 1900, emotions ran high and disagreements were.bitter. Violence occurred on several occasions and numerous heads were literally cracked in the wars. 19

Because fights were often between different fishing gear operators, a brief description of the types of fishing gear used prefaces the history of gear regulation.

\section{Fixed and Floating Gear.}

Basically there were two types of fishing - fixed and floating gear operations. Fixed gear remained stationary and was attached in

17Fish Commission of Oregon, Washington Department of Fisheries, Status Report Columbia River Runs and Commercial Fisheries, 1938-70, Portland: State of Oregon, 1970), p. 58. Iists the 1970 catch. Commercial 405,000 pounds, Sport 142,700 pounds, Indian 954,200 pounds Total 1,502,300 pounds of chinook salmon.

18United States Department of Commerce, 1970 Census of Population; General Population Chrracteristics - Oregon. (Washington D. C., G.P.O., I971, p. 45.

190regon Fish Commission, The Effects on Salmon Populations of the Partial Elimination of Fixed Fishing Geer on the Columbia River in 1935 (Partland: State of Oregan, 1950), Cantribution No. 11, p. 5. 
various ways to the river shore or bottom. Floating gear was not attached and could be moved over a considerable area of the river in one night.

Fixed Gear

Fish Traps. The fish wheel was a large water wheel with a series of small buckets. The wheel depended upon the current for its motion and revolved day and night, with a minimum of human attention. As the wheel turned, buckets which opened downstream scooped through the water. Fish moving upstream entered the bucket, were revolved from the water, and into a chute.

Set Nets. The set net consisted of a single wall of gill netting secured in a fixed position.

Seines. Several types of seines have been used on the Columbia River. One of the most common types was the beach or haul seine. Essentially, it was a single curtain of webbing attached to a cork line at the upper edge and to a lead line at the lower edge. Lines were attached to both ends for use in pulling in the net. Floating Gear

Gillnets. Two general types, floater and diver nets were (and still are) used. Gillnets operate by trapping moving fish who become tangled in the web of the net by their gills. ${ }^{20}$ Gillnets are the only form of floating gear used commercially.

In general, one form of stationary gear did not interfere with

20 State of Washington Department of Fisheries, Columbie River Commercial Fishing Regulations from 1866 to 1961. (Seattle: State of Washington, 1961), pp. 2-5. 
another except in general competition. Problems occurred when floating gear interfered with fixed gear. 21 One form of fixed gear, the fish wheel, generated a considerable amount of conflict.

\begin{abstract}
From their first appearance on the Columbia River in 1879, Fiahwhol arouged the doop hatrod of net fisharmen and oharp jealousies among operators of the wheels themselves, resulting in some of the kitterest and greediest battles in the history of any fishery. 22
\end{abstract}

The British writer, Rudyard Kipling, saw fish wheels for the first time when he visited the Pacific Northwest in the summer of 1889. His description of them echoed sentiments of net fishermen. He described them as an "infernal arrangement of wirepgauze compartments worked by the current to scoop up the salmon as he races up the river." 23

As the fish fights flared between wheel operators and net fishermen, the fear of depletion of the runs also grew. Consequently, the State of Oregon began to regulate the use of fish traps, weirs, seines and nets. In 1890 the State prevented fixed gear from being used more then halfway across any channel or slough. One year $\ddot{l}$ ater, the regulation was stiffened to permit only a maximum extension across one-third

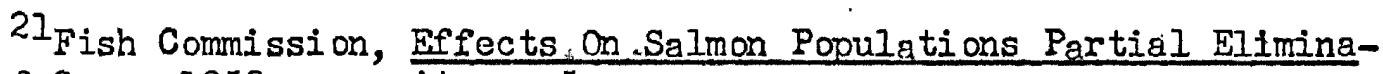
tion of Gear, 1950, op. cit. p. 5.

22 Ivan J. Donalds on and Frederick K. Cramer, Fishwheels of The Columbia (Portland: Binfords and Mort. 1941), p. 7 .

23 Ibid., p. 7. 
of a channel or slough. 24

However these moderate restrictions were incapable of adequately protecting the resource. Consequently, by the turn of the century, runs of the Columbia River had declined to the point where the catch of smaller and poorer fish had become more important. ${ }^{25}$ The decrease in the fish muns did not lessen the conflict. Bitter battles were fought among the various gear operators. 26

Fish and Garne Board Quarrels

In addtion to conflicts between commercial gear operators, there was the beginning of sport and commercial fish fights. In the early 1900 's through World War I these groups repeatedly fought over fish and game boards. Consequently, a discussion of the boards and the quarrels between anglers and commercial fishermen is necessary.

Shortly before the beginning of the twentieth century, the need for governmental protection of fish and game was recognized. The legislature provided for a board to protect fish and game in 1893. However, in 1899 legislation was passed which formed separate boards for fish and game. 27 These boards lasted until 1911. At that time they were pp. $2-5$.

24Washington Dept. of Fisheries, Columbia Gear Regulations, 1961,

25Dept. of Interior, History and Development Fisheries of the Columbia, 1940, p. 197.

26Fish Commission, Effects on Salmon Populations Partial Elimination of Gear, 1950. p. 5.

27Clark Walsh, 'The Good Old Days' A Review of Game and Fish Administration in Oregon, (Oregon State Game Commission, Portland, 1960) p. 3 . 
again merged by the creation of a board of fish and game commisstonerssimilar to the 1893 board. This consolidation proved to be a reorganizational disaster. Four of the five members resigned when anglers and their allies attacked the fifth member of this restructured governmental body. $^{28}$ The fifth member, M. J. Kinney, a cannery man was the only member who remained. 29

In 1915 the Board of Fish and Game Commissioners, established in 1911, was abolished and a Fish and Game Commission was created In its place. But the life of this commission was to prove 111 -fated. 30 By 1919 the sport fishing interests were again demanding a separation of functions.

On March 25, 1919, the Oregon Sportsmen's League announced its intention to initiate a measure at the next general election to separate the functions of the Fish and Game Commission concerning commercial and game fish. 31 By the 30th of March that year, Governor Ben Olcott had received three petitions calling for the investigation of the Fish and Game Commission. The first petition was from the Sportsmen's League. The second was from the Multnomah Anglers' Club and the third from the

28"Kinney, They Say Is Like Fifth Wheel on Commission Cart," Oregon Journal, 29 Nov. 1913, p. 8, col. 4.

29 "Fish and Game Departments Do Not Now Exist", Oregon Journal, 29 Nov. 1913, p. 8, col. 2.

30 Walsh, Good OId Days, 1960, p. 5.

31"Sportsmen Will Carry Fight To People At Polls", Oregon Journal, 25 Mar. 1919, p. 15, col. 1. 
State Fish and Game Commission itself. The Multnomah Anglers' Club pointedly proposed that the Governor select an accountant to prove or disprove the sportsmens' allegations that the state game fund had been applied to the propogation of commercial salmon, instead of non-commercial trout and game birds. ${ }^{32}$ Recognizing the political influence of the states' anglers, the Governor decided to act. On December 21, 1919, the Oregon Sportsmen's League announced its intention to initiate a measure at the next general election to separate the commercial and game fishing functions within the Fish and Game Commission. 33 The initiative became unnecessary when the legislature acted on the problem. On January 16, 1920, the Governor signed a bill creating a single board but retaining two separate operating units. This reorganization lasted until 1921.34 The State Legislature then created two separate commissions: the Fish Commission of Oregon, and the Oregon State Game Commission, (renamed the Mildlife Commission in January of 1974).35

\section{Gear Regulation}

While sportsmen and commercial fishermen fought legislative battles over boards and commissions, the gear operators continued their wars:

32 "Charges Against Game Commission Create Interest, "Oregon Journal, $30 \mathrm{Mar} .1919, \mathrm{p} .15, \mathrm{col} .1$.

33"Sportsmen Will Carry Fight To People At Polls", Oregon Journal, 25 Mar. 1919, p. 15, col. 1.

34"Olcott Signs Bill Ending Fish Tangle," Oregon Journal, 16 Jan. 1920 , p. 1, col. 3 .

35 Telephone Conversation with LIoyd Smith Information Expediter, Information and Educetion, Oregon Wildlife Commission Portland, Oregon, 14 Apr. 1975. 
Legislation to bar purse seines was originally passed in 1907. Two years later, the legislature hed given in and the purse seines were again. licensed on the river. By the end of World War I, the State of Oregon and the State of Washington had again probibited purse seines. These see-saw legislative actions indicate the various pressures felt by legislators. These pressures included the attempts to conserve the resource as well as the various fights between fixed and floating gear interests for a monopoly of the supply. This struggle for control did not abate. In the following years, the conflict between trap owners, seine operators, gillnet fishermen and others continued. By the 1920's a strong campaign against fish wheels was building. In 1926 a ballot measure passed to prohibit the use of fish wheels. ${ }^{36}$ However, at least one wheel operated beyond its legal time. Stoppage of the most famous of them all, Fishwheel No. 5, marked the end of an era: No. 5 was stopped by court order on July 1, 1927. This revolving scoop caught more fish and made more profit than any other wheel on the Columbia and probably in the world. No. 5 located at five mile rapids near the Dalles, Oregon, had been the focus of contention during the many years of fish conflicts between Seufert Brothers Company and fishermen of the lower Columbia. No. 5 caught 417,855 pounds of salmon and related species in 1906, the largest amount taken in any season by any wheel in the area. It averaged approximately 73 tons per season during its life. The lowest yearly catch was ten and a half tons in 1926.37 With a rate of catch this

36Donalds on \& Cramer, Fishwheels 1971, p. 7. 37 Ibid., p. 91. 
high the wheel was bound to generate ill will. Many net fishermen did not catch as many fish in one season es No. 5 did in one day.

The movement against fixed gear increased in momentum. In 1927 the Oregon Iegislature barred traps and seines above Cascade Locks and set a maximum gillnet length of fifteen-hundred feot. By 1935 the State of Washington had barred drag seines; the state also ruled out wheels, traps and other fixed gear. Washington also adopted the same maximum length for gillnets as Oregon. However, in 1935 oregan reconsidered and permitted seines east of Cascade Locks. ${ }^{38}$

At the beginning of World War II the fish fight took a more modern form. By 1942 sports fishermen were beginning to move against the commercial industry. Sportsmen desired the closing of ocean feeding streams to gillnetting, so they acted and obtained a measure on the ballot. However, the industry responded with a timely and successful advertising campaign to block this move. For example, it carried an advertisement in the November 2, 1942 issue of the oregonian featuring a smiling oriental. It asked in bold print: WILL YOUR POTE MAKE HIRO HITO HAPPY? VOTE $311 X$ NO AGAINST THIS UN-AMERICAN MEASURE WHICH KEEPS ORDGON SALMON FROM YOUR SOLDIERS. 39 The patron of this newspaper advertisement was Charles Henne, Secretary of the Oregon Fishermen's Protective Union. 40 (In one of those strange turn-abouts that one finds p. 7. ${ }^{38}$ Washington Dept. Of Fisheries, Columbia Gear Regulations, 1961 , ${ }^{39}$ Oregonian, 2 Nov. 1942, Section I, p. 5. cols. 5-8. 40 Ibid. 
of ten in politics, Henne was registered as a lobbyist for the Oregon Wildlife Federation in 1969.41 Henne assisted the effort to make a steelhead a game fish in the 1969 legislative session). Although the sportsmen were unable to close coastal streams to commercial fishing, in 1946 they combined with their former gillnet opponents against trap and seine operators. The Oregonian ran an editorial in 1948 which supported the drive to remove traps and seines.

The fish fight will return to the Oregon ballot November 2 in a measure, initiated by union gillnet fishermen and sports fishermen, to outlaw in waters of the Columbia and its tributaries "any pound net, fish trap, (etc.)."

It would ban, that is, all stationary gear -- It would bring Oregon and Washington fishing methods into uniformity, and reduce friction between the states caused by the netting of steelhead on Washington's side of the channel (where they are declared by Washington law to be game fish and their marketing. on the Oregon shore). It would improve the escapement of steelix head to the spawning streams of oregon, as it has in Washington.

The gillnet fishermen want to avoid the step taken by Washington, declaration of the steelhead as a game fish, because it seriously limits chinook and silver fishing: They contend that with fixed gear removed, and a proper mesh law, an 80 per cent escapement of steelhead-i The great sports fish of the Northwest-- can be assured. The formula is worth a trialr-

In the seven years before Washington abolished fixed gear, traps took an average of 15.3 per cent of the totial Columbia catch, set nets took about 1.5 per cent, seines took 16.7 per cent and gillnets 63.1 per cent.

In twelve years following the Washington change, set nets continued to take about 1.5 per cent; the take in traps dropped to 3.8 per cent (and the number of traps decreased by almost 90 per cent, because the best trap sites were on the Washington shore): seines averaged 14.3 per cent (the best seining grounds being on the Oregon side), and the gillnet catch increased to 70.7 per cent.

4Istate of Oregon, Office of Leglslative Counsel, 410 Ștate Capitol Room 109, Form 142 A- 466 . 
Obviously, the gillnetters benefited most from abolishment of fixed gear on the Washington shore, and this has been the principal argument of packors and other fixed gear operators against the initiative. They contend that it is discriminatory to rule out one type of gear to the benefit of another.

The point would be valid were it not that traps and seines, with smaller mesh than gillnets, do not provide proper escapement for steelhead, small salmon and cutthroat.

Sportsmen, convinced of improvement in angling for steelhead, cutthroat and salmon in Washington's tributaries of the Columbia since 1935, have thrown their weight. With the gillnet fishermen to obtain similar benefits to Oregon streams. Sport fishing itself, is a big industry, surpassing in importance the fixed gear.

This page recommends approxal of the measure, No. 318 on the ballot, to abolish traps, seines and other fixed gear on the Oregon shore of the Columbia River. 42

The coalition of the more numerous sport and commercial fishermen against the fixed gear operators was successful and the ballot measure passed. This combining of interests illustrates the general trend that occurs and reoccurs on the Columbia. The stronger groups combine and they force weaker ones from the riwer. In this case, gillnet and sport fishermen were stronger, with gillnet fishermen the best organized. The less powerful fixed gear operators took less fish, yet they were excluded. As a simple analogy, this process is not unlike the game of Monopoly or a primary election campaign. Only the strongest survive and they force the losers from the game, from office, or in this case from the river.

The Oregonian editorial, supporting the removal of traps and seines

42 Editorial, "Toward Sustained Yield Fishery," Oregonien, 11 oct. 1948 , p. 10, col. I. 
mentioned the future source of discontent between anglers and gillnetters. The net fishermen wanted to avoid legislation designating steelhead as a game fish. Steelhead, and occasionally salmon, were to become objects of bitter fights between the future combatants. In addition, several court battles over these fish would, in the future, give the Treaty Indians their fishing rights.

Although traps and seines were outlawed, the owners of both forms of fixed fishing attempted to prevent the inevitable. Seine operators requested a two year moratorium to allow them to wear out their gear. Both the House and Senate were lobbied by seine interests. A bill was introduced in both chambers on their behalf but trap owners were not included on this bill. Not surprisingly, the owners of traps appealed for equal treatment prior to the House vote. However, the seine interests were opposed with good reason, to inclusion of trap fishing. Seine operators were afraid that any association with trap owners would jeapordize their chances for a protective waiting period because the trap interests had developed a poor image in the 1948 campaign. Sport and gillnet fishermen had effectively used a negative advertising campaign concerning "bear traps" to sway the voters. The implication had been "DON'T USE BEAR TRAPS ON OUR SALMON." 43

Finally, a bill was introduced in the House to protect the trap operators. This bill was produced partially through efforts of Representative Grace O. Peck, a first term legislator. However, on the dey of the vote, the trap moratorium bill was not in the committeo hopper.

43Grace 0. Peck, Oregon State Representative, District 6-Multnomah (South): interview held at St. Philip Neri Catholic Church, PortIand, Oregon, Aug. 20, 1972. 
Chalrman Hill of the House Committoe on Floheries was literally holuirig, the bill in his hip pocket. Representative Peck gave a highly colorful account of how the bill was moved out of committee. She stated that Chairman Hill had mysteriously disappeared. She looked everywhere but he was missing. The last plece she searched for him was the mens' rest room. She knocked on the door and called his name; immediately she heard chudkling from within. Peck then sent several male legislators after him, and he emerged from his hiding place with his group escort. According to Peck, Hill was smiling and was highly amused over the situation. Apparently Hill's good humor prevailed and he allowed the bill to come to a vote. The legislation passed the house, but gillnet and sport fishermen were able to persuade Governor McKay to block the measure when it reached the senate.44 Representative Peck's colorful description of the legislative process illustrates just another step in the fight over fish. The seine fishermen were driven from the river and did not band together with trap interests. It had become literally every interest for itself. The seine fishing interests protected themselves, and trap owners lost out on the two year moratorium. This same singleminded protection of interest was to be repeated again and again in the years that followed.

\section{FOURTH PERIOD: SPORT, GILINET AND INDIAN FISHING}

Eventualiy the sport fishermen began to move against their former allies. They became dismayed as the decline in their sport fishing continued. In 1957 sport-sponsored initiative campaigns had closed to com-

\section{Ibid.}


mercial fishing all coastal streams south of the Columbia except the Tillamook River. 45 This opposition to commercial fishing continued with a focus on steelbead fishing. In 1957 the Oregon Fish Commission had closed the Columbia River to commercial fishing of winter steelhead during December and January. A joint conference of the Oregon Fish Commission and the Washington Department of Fisheries was held concerning closing the Columbia to commercial fishing beyond the month of. January. This meeting resulted in a refusal by the Oregon Fish Commission to restrict commercial fishing for steelhead. Politically active sportsmen from the State of Washington had claimed that their State Department of Game was propogating substantial numbers of steelhead for Oregon's commercial nets. The Fish Commission denied the Washington sportsmens' claim and opened the river. 46 However, it was no surprise to anglers and commercial fishermen alike that the steelhead issue would not die. In 1961 efforts were made by sports groups to attempt an initiative to designate steelhead a game fish. A bill to do the same was also introduced in the Legislature. Both efforts were barren. 47 However, in 1962 another initiative was attempted. This time the gillnet interests went

45Save Our Salmon and Steelhead, Inc Reference Guide Factual Information on Sports and Commercial Fishing for SaImon etc. (Portland: Save Our Salmon and Steolhead, Inc. n. d.), p. 4 .

46!Washington Steelhead Claim Denied at Meet" Oregon Journal, 14 Feb. 1957, p. 3, cols. 2-5.

47Portland Chapter Association of Northwest Steelheadears, Steelhead trout. Game Fish ar Food Fish 50 years of Indecisi on (Portland: Association of Northwest Steelheaders, n. a. ), pp. 5-6. 
to court to block the sportsmen. The Suprerne Court of Oregon overturned Attorney General Robert Y. Thornton's ballot title for the initiative. The court order was a clear victory for commercial fishing. The abortive initiative had been designed to declare steelhead a game fish. This initiative would have prohibited all commercial fishing on the Columbia until September 30th each year. This closure would have allowed ten per cent of the summer run to be caught by sportsmen before allowing commercial fishing prior to September 30.

Sport fishing groups were very agitated by the court ruling. Sportsmen had fulfilled all the necessary requirements for their initiative through the Attorney General's office. Also, they had been assured by qualified personnel in the Attorney General's office that they had obtained edequate signatures. The initiative proponents were very angry because they had also checked the legality of the initiative with the Secretary of State. They were under the impression that they had complied with the requirements from that office as well as the Attorney General's office. 48 They found out, however, through a bitter experience that the courts can rule out ballot titles even though state officials approve them.

In 1964, sports fishermen were again active and they had a new measure on the ballot. This measure was designed to remove steelhead and salmon from commercial fishing on the Columbia. The industry responded with a skillful mass advertising campaign. This time the mesSage was: DON'T FORCE AN ENTIRE INDUSTRY IMPORTANT TO OREGON'S ECONONY

\footnotetext{
col. 8.

48 "Vote Title Revamped", Oregon Journal, 19 April 1962, p. 1.
} 
TO MOVE TO THE STATE OF WASHINGTON! IF THE MEASURE PASSES THE HOUSEWIFE MAY NOT BE ABLE TO GET SALMON IN THE FOOD STORE. 49 These messages were quite effective. In the 1964 general election, the industry campaign struck down the initiative by 534,731 votes to $221,797.50$ Anglers had misjudged the situation. By attempting to remove both steelhead and salman from commercial fishing on the Columbia, they had taken on too much. The threat was great to the industry. Consequently the industry had waged a vigorous and successful campaign to protect commercial fishing. 51 The industry had very adroitly played upon fears that there would be no salmon on the grocery shelves.

For a time after defeat of the 1964 measure the fish controversy resembled the fights in the early 1900 's over fish and game boards. In February of 1965 a bill was again introduced in the legislature to merge the Fish and Game Commissions and the House approved the bill. 52 However, the active sportsmen steadily apposed this measure. The Izaak Walton League was very critical of the manner in which license fees of sportsmen were to be used. Spokesmen for the League alleged that giving of fees to the proposed organization would give them to the commercial

49Charles Collins, (former) President Oreg on State Izaak WaIton League, interview held at the Sheraton Hotel, Lloyd Center, Portland, Oregon, Jul. 17, 1972.

50 Assn. of N. W. Steelheaders, Steelhead Ggme Fish or. Food Fish, n. d. p. 9.

5lInterview with Charles Collins, op. cit.

52"Fish Game Merger Approved", Oregonian, 23 Feb. 1965, p. 9, cols. $1-3$. 
interests. 53 Surprisingly, commercial interests were also not in favor of the bill. The industry was in mild opposition to the proposed legislation. However, if there was to be a merger, it wanted Hause ameridments on which it had lobbied left in the bill. As it turned out, the bill did not pass the Senate. 54 The Oregon Fish Commission and Governor Mark Hatfield were almost alone in their disappointment over the loss of the bill.

Treaty Indians vs Oregon

In the early 1960's the Indians began to have serious disagreements with the State of Oregon. By July of 1963, the Indians from the Umatilla Reservation obtained an injunction against the state for enforcing bans on fishing. 55 In October of 1965, Governor Hatfield sent a letter to Secretary of the Interior, Stewart Udall, strongly objecting to Federal regulations governing off reservation fisbing by Indians. The Governor also sent a letter to Oregon Attorney General Robert Y. Thornton requesting that he bring the full power of the state behind prosecution of state laws. Hatfield stated that the treaty intent could then be settled in court. 56 Meanwhile, the State began to prepare for enforcement. On January 6, 1966, Robert Schoning, Director of the Oregon Fish

53"Fish Game Merger Approved", Oregonign,23 Feb.1965,p.9, cols.1-3. 54"No Fish-Game Merger", Oregonian; 24 Mar. 1965, p. 22, col. 1. 55 "Judge Solomon Refused To Ban Indian Fishing At Three Mile Dam And Nearby Areas", Oregonian, 23 Jul. 1963. p. 9, cols. 1-8.

56"Hatfield Bars J. S. Proposal", Oregon Journal, 14 0ct. 1965, p. 1, col. 8. 
Commission, stated Oregon's new policy of enforcing fishing laws. He explained that in the past, Indians who violated state law were prosecuted only when they were also in violation of tribal law. However, state law enforcement agents would now act whether or not tribal ordinances were violated. 57 This hard line policy resulted in arrests. On April 16, 1966, two Indians were arrested for gillnetting salmon on the Columbia River. ${ }^{58}$ These arrests were the first in a joint enforcement program by Oregon and Washington. These tribal fishing arrests continued and on Nay 2, 1966, the Federal Government responded. Edwin L. Weis Jr., Assistant United States Attorney General, gave the government's. strong support to Indians who were arrested for practicing tribal fishing rights. Weisi stated: "We view the arrest of Indians who conform to tribal regulations as a very serious matter." Weisl added that a treaty with the Indians is as "binding as any treaty with a foreign nation."59 The conflict continued and the Indians became indignant to the point of violence. On July 31, 1966; five Washington game wardens were held at gun point by tribal Indians near Stevenson, Washington. 60 This was the an $1 y$ incidence of armed conflict, although the basic struggle continued.

57Jerry Tippens, "Oregon Ready To Crack Down On Indians who Violate State Fishing Laws", Oregon Journal, 6 Jan. 1966, p. 2, cols.I-8. 58"Game Agents Jail Indians", Oregonian, 16 Apr. 1966, p.7, col. 3.

59 "U. S. Moves To Clear Up Furor Over .Indian Fishing Rights", Oregon Journal, 2 May 1966, p. 2, c.0ls. 2-4.

60 "Indians on Warpath To Preserve Fishing", Oregonian, $31 \mathrm{Jul}$. 1966, sec. 3, p. 9, cols. $1-2$. 
In June of 1968, the U. S. Supreme Court ruled partially in favor of the states and partially in favor of the Indians. The Puyallup decision by the high court gave states the right to regulate for conservation of the runs. However, the court indicated that the treaties remained in force and that Indians possessing treaty rights retained the right to fish in their "usual and accustomed places." The Court also indicated that the state could not discriminate against Indians in its regulations. 61 Unfortunately, the Court decision was vague enough that both contending parties interpreted the decision as an affirmation of its stand. 62 Consequently, oregon and Washington continued to follow a rather stringent policy of enforcing bans on Indian fishing of the reservation. Not surprisingly, the situation did not significantly improve. On August 1, 1968, U. S. District Judge Gus Sol omon threatened to issue an injunction against the State of oregon uriless it ceased the arrests of Umatilla Indians fishing on Northeast Oregon streams. Eventually the State complied and no injunction was necessary. 63 However, agitation continued until early.1969. In April of 1969, a milestone decision was made. J. S. District Judge Robert C. Belloni ruled that:

\footnotetext{
6l"Indian Rights Declared, "Oregonian," 2 June 1968, Sec. F, p. 2., col. 1.
}

62George Dysart, Assistant Regional Solicitor; Department of The Interior, interview held at Bonneville Power Building, Portland, Oregon, Sept. 9, 1974.

63"Judge Rules Indians May Fish In 'Usual Accustomed Places' Wi thout Arrest," Oregon Journal, I Aug. 1968, p. 7, cols. 1-8. 
Oregon recognizes sports fishermen and commercial fishermen and seems to attempt to make an equitable division between the two. But the State seems to have ignored the rights of the Indians who scquired a treaty right to fish at their historic off-reservation fishing stations. If Oregon intends to maintain a separate status of commercial end sports fisheries, it is obvious a third must be added, the Indian Fishery. The treaty Indians, having an absolute right to that fishery, are entitled to a fair share of the fish produced by the Columbia River system. 6

The Belloni decision emphasized the necessity of recognizing the Indian fishery as a co-equal fishery with sport and commercial fisheries. The decision also required the State to insure that the treaty Indians would gain their fair share of fish. In addition, Belloni maled that the State of Oregon must give proof of the necessity of conservation before limiting Indian treaty fishing. 65

Sport - Commercial Steelhead Fight

In 1967, commercial interests.won another victory in the commercial sports conflict. The Oregon House of Representatives voted against giving the State Game Commission veto power on Fish Commission escapement closure decisions. 66 The angler - gillnetter strife continued.

64Sohappy V. Smith 302 F. Supp. 899 , D. Ore. (1969). Although the Belloni decision gave Indians the right to a fair share of the catch, the formula for this share was not decided until 1974. Federal District Judge George Bold's of the State of lashingtan decided that Indians could catch up to 50 per cent of the off reservation fish. At their "usual and accustomed" fishing places, after escapement for conservation of the run. American Law Division, to Hon orable Lloyd Means, The Iibrary of Congress, Congressional Research Service, Washingtor, D. C., Feb. 12, 1974.

65 Sohappy V. Smith 302 F. Șupp. 899, D. Ore. (1969).

66Harold Hughes, "Steelhead Game Fish Label Out," Oregonian,

23 Apr. 1967, sec. 1, p. 1, c01. 7. 
Because of these constant flghts, Govern or McCall attempted to develop a solution to the growing struggle over steelhead. In the early spring of 1967, the Governor met with sport and commercial group representatives and attempted to porsuade both sides to work in a splrit of compromise. His besic arguement was that "There is no sense in continuing an embarrassing campaign for the sportsmen and a potentially disastrous fight for the packing industry." 67 Initially, the meetings the Governor spansored began in an agreeable manner. However, as they progressed, both groups developed stronger positions until hard lines were taken by both sides. The sportsmens' view was to cut commercial fishing completeIy out of steelhead runs. On the other hand, the industry had as vehement a view as the sportsmen. The industry was in complete opposition to the idea of declaring steelhead a game fish. Never theless, Governor McCall and his Administrative Assistant Kessler Cannon, talked frequently with both sides throughout 1968 and during the legislative session of 1969, in the hope of resolving the dilemma. On the game fish side of the controversy the Governor and Cannon met with the Izaak Walton League, the Pacific Northwest Association of Steelheaders, and the Oregon Wildlife Federation. The Governor and his assistant also met with fishing industry representatives, including John McGowan, President of Bumble Bee Sea Foods, Incorporated. (A subsidiary of Castle and Cook, one of

${ }^{67}$ Kessler Cannon (former) Administrative Assistant Department of Natural Resources, to the Governor. Two interviews held at the State Capitol, Salem, Oregon,0ct. 14, 1969 and Jul. 26, 1972. 
the five largest corporations in. Hawaịi.) McCall and Cannon met with McGowan as his company had the major interest in Oregon's salmon fishing. Governor McCall kept asking the industry to help by allowing steelhead to be named a game fish. The fishing rights of the industry would be protected by an incidental catch provision. However, commercial interests were not open to the idea of designating steelhead a game fish and would not support the executive position.

At the beginning of the 1969 legislative session the sport and commercial interests were becoming increasingly inflexible.. the possibility of a compromise on steelhead appeared dim. 68

68 Ibid. 
CHAPTER III

THE WHY OF THE CONFLICT

DECLINE OF THE RESOURCE

As indicated in chapter II, the fish resource of the Columbia began to decline in the late $1800^{\prime} \mathrm{s}$, due largely to over-fishing. This chapter focuses on recent declines.

Is present day commercial fishing damaging the fish resource of the Columbia River? Fish Commission research personnel have been studying the decline of the muns. They have come to several conclusions (predominantly on non-hatchery fish). C. J. Junge. of the Fish Commission Research Center considers the possible demage of commercial fishing:

Now, let us look at the other factor that could decrease runs -decreased escapement due to over-fishing:

Here we have studied the average escapements that reduced our runs, and, for an equal number of years, the average escapements for the earlier years for good production. (Note Values) [Junge is referring to table 1.]

...Clearly, all escapements are quite a bit better for the recent years. With increased escapements in recent years, the downward trends cannot be due to over-fishing with reduced escapements. We can see; on the other hand that the reduced runs are a consequence of the reduction in the return per spawner. (Note Values, )... I

${ }^{I_{C}}$. J.'Junge, "Can We Maintain Our Salmon and Steelhead Runs In The Columbia River?" (Portland: Copy of Speech Presented At Oregon Wildiffe Federation Meeting, Jan. 13, 1968.), p. 6. 
TABLE I

ESCAPEMENT AND RETURN PER SPAWNER

Species Years of High Production Years of low production

$\begin{array}{llll}\text { Average } & & \text { Average } & \\ \text { Yearly } & \text { Return } & \text { Yearly } & \text { Return } \\ \text { Escape- } & \text { : Per } & \text { Escape } & \text { Per } \\ \text { ment } & \text { Spawner } & \text { ment } & \text { Spawner }\end{array}$

Spring

Chinook $\begin{array}{llllll}1939-51 & 50,300 & 3.23 & 1952-65 & 83,100 & 2.03\end{array}$

Summer

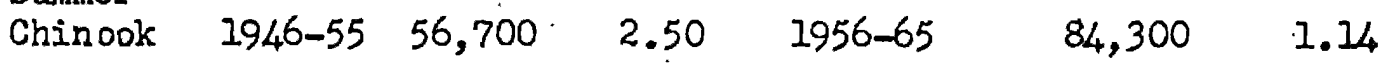

Surmer

Steelhead $1938-50 . \quad 84,700 \quad 3.09 \quad 1951-65 \quad 136,800 \quad 1.54$

AlI

$\begin{array}{lllll}\text { Species } & 226,700 & 3.18 & 385,100 & 1.55\end{array}$

SOURCE: C. J. Junge, "Can We Maintain Our Salmon And Steelhead Runs In The Columbia River?" (Portland: Copy of Speech Presented At Oreg on Wildlife Federation Meeting, Jan. 13, 1968). 


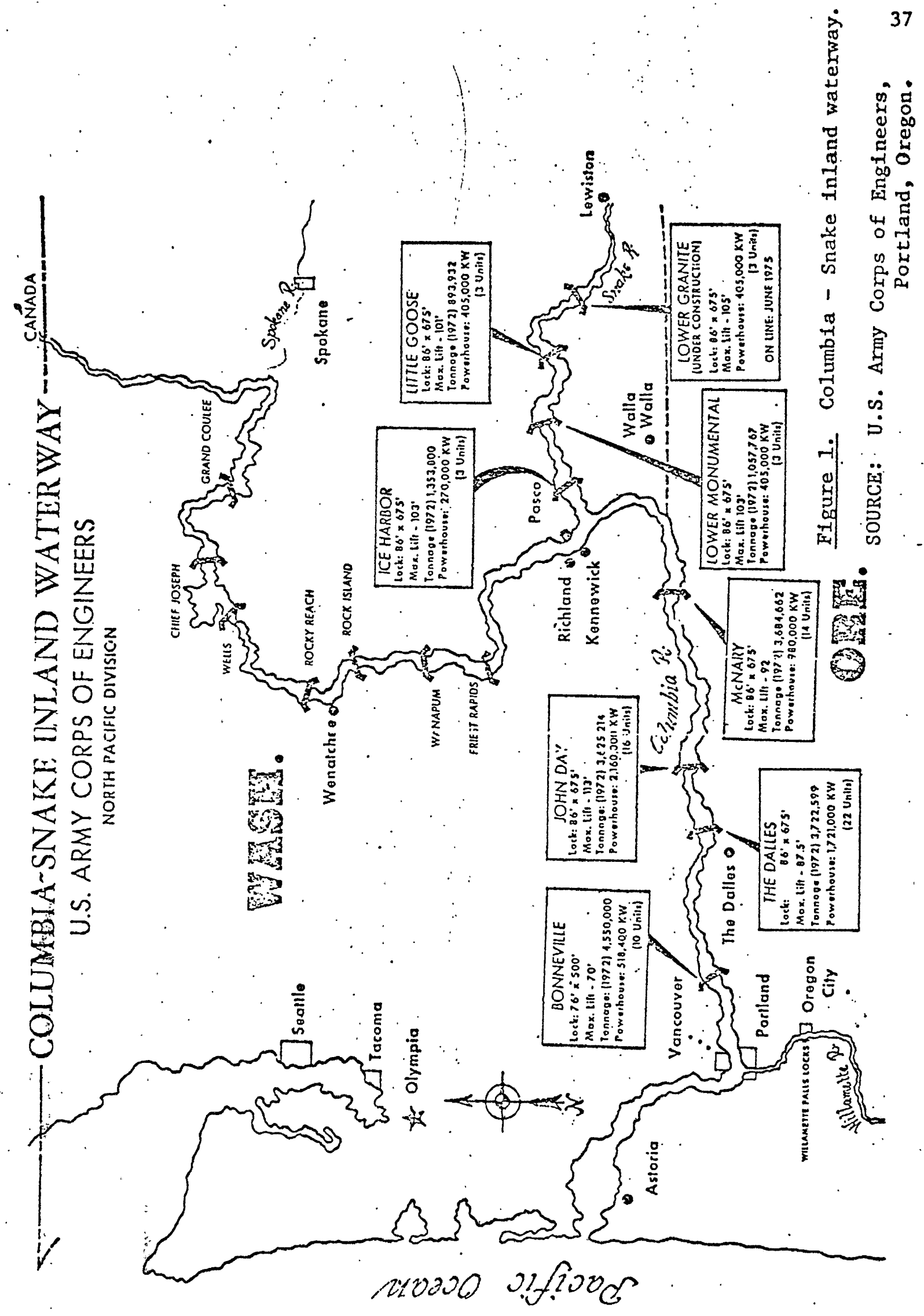


THE ROLE OF DAMS

... Now let's consider what could have influenced salmon and steelhead runs since 1956. Here we have the engineers' dream and the biologists' nightmare-- a map [sic] of the main-stem dams on the Columbia River and the Snake River.

Completion dates are given for each dam. Actually, there are dams already under construction, approved or proposed that I have not listed...

According to research specialist Junge, there were no dams built on the Columbia between 1941 and 1953. During this period the returm per spewner (Table I) was higher than the return per spawner after 1953. Prior to 1953, the fish runs were recuperating from the effects of dams already built. However, the lull in dam building did not last. Between 1953 and 1970 the following ten dams were constructed: 3

$\begin{array}{ll}\text { McNary (and Chief Joseph) } & 1953 \\ \text { The Dalles } & 1957 \\ \text { Brownlee } & 1958 \\ \text { Priest Rapids } & 1960 \\ \text { Rocky Reach and Oxbow } & 1961 \\ \text { Ice Harbor } & 1962 \\ \text { Wanapum } & 1963 \\ \text { Wells } & 1967 \\ \text { Lower Monumental } & 1969 \\ \text { Little Goose } & 1970\end{array}$

\section{Ibid., pp. 6-7}

3C. J. Junge, Oreg on Fish Commission, Research Division, interview held at Management and Research Division, Clackamas, Oregan, 28 Jul. 1974. 
During this period (1953-1970) the upriver runs suffered the first serious break in production in 1956. The loss of production did not appear until 1956 because the majority of salmon and steelhead were out to sea for two years. Downstream migrants passed over McNary for . the first time in 1954, with direct mortalities occuring to these juvonile snlmin going through the turbines and over the splils of MaNary Dam. The erosion of the runs passing downstream was (and still is) about 12 per cent of the mun. This 12 per cent loss does not include predation or losses from stunned fish. However, the combined losses from these sources do not explain the large drop in the runs in 1956. Anothor factor creates additional loss through predation. The dams create forebays-lakes behind the dams which are large bodies of sluggish water which the fish must pass through. The forebays leave salmon and steelhead more accessible to predators--such as squaw fish. The slower flow also causes silt to settle more readily, which results in a loss of rocky pebble bottom and thus there are fewer places for salman and steelhead to hide.

Direct mortalities to fish going over McNary and losses due to predation explain some of the high losses of fish that began in 1954 and became apparent in 1956 when the down stream migrants returned from the sea. However, the bulk of the high loss since 1956 is explained by noting that fatalities of more than 20 per cent can occur to adult salmon below Bonneville Dam passing upstream during periods of high flow. At the Dalles, there were 20 per cent or more of spring and summer chinook upstream migrants missing. At McNary Dam, about 15-30. 
per ceñt of spring chinook were lost. Formerly, McNary wgs considered to have caused a loss of approximately 15 per cent. Since the building of John Day Dam this loss has increased to a tot 1 of 30 per cent, a substantial figure. (To keep this loss in perspective we need to recall the situation before the Dalles Dam was built; at that time fish had to climb over the natural obstacle of Celilo Falls.) By examining specific muns we can see where the heaviest losses are concentrated.

In the last column we listed the percent of salmon that are unaccounted for between the dams. Note the number for spring chinook and steelhead and strong upward trend for summer chinook and steelhead. (Table II)

Now in conjunction with losses below Bonneville, the Dalles, and McNary, the superimposition of these losses are claarly of concern. For example, in 1965 the cumulative losses of spring chinook for all dams below Priest Rapids and Ice Harbor were about 70 per cent.

By now you have probably noticed one common feature of all the runs that are designated as being in trouble-their spawning areas are all in upper tributaries while none of the runs that have been okayed are. [si] This means, of course, ta that the adult salmon and steelhead of the runs that are in trouble must climb up a series of dams to reach their spawning grounds, and that the dounstream fingerlings must swim through the forebays of these dams and then pass over the spillways, or go through the turbines at each of these dams $4 .$.

Most of the hazardous environmental conditions to fish caused by dams have been indicated. Unfortunately, there are others. Recently, a new and highly dangerous condition has been observed:

\footnotetext{
4Junge, "Can We Maintain Our Salman" speech, Jan. 13, 1968, op. cit. pp. 4-8.
} 


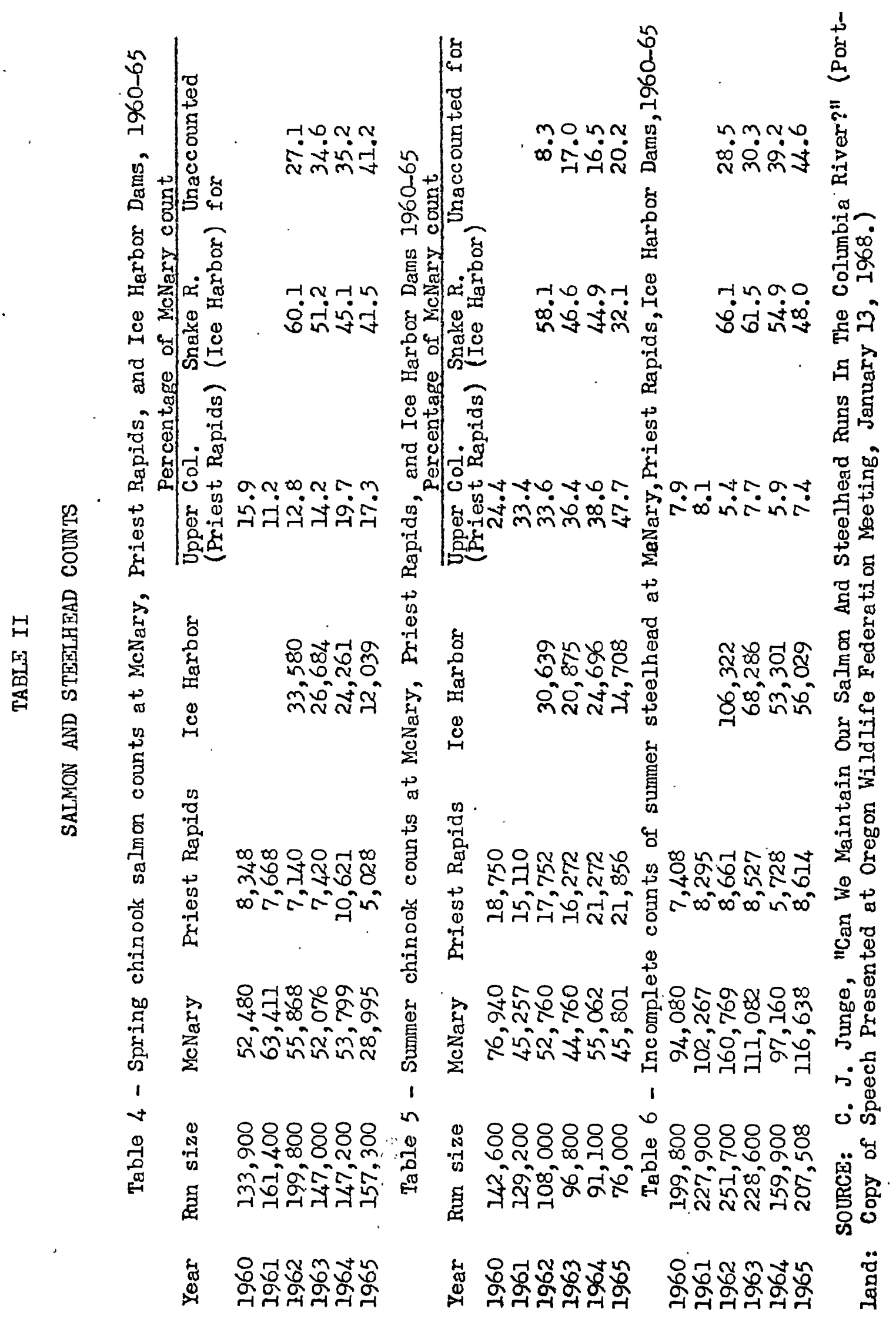


The greater pressures deep below the surface of a dam pool force nitrogen into solutions measured up to 42 per cent above normal.

Fish biologists say nitrogen solutions over 10 per cent of normal can injure a fish and those more than 25 per cent above normal are usually fatal.

This is a gas bubble disease, a condition akin to the bends. In 1971 it killed 90 per cent of the salmon and steolhead runs in the Columbia River and its tributaries, by estimation of the National Marine Fishories Service. This year it could be even greater. 5

Even though the problem of supersaturated nitrogen is very serious, it is a seasonal threat, because this condition occurs during spills when the dams are passing huge amounts of water. Super-saturation is so dangerous because the Columbia no longer runs free. Instead of a strong flow to dissipate the supersaturated nitrogen, the compressed gas remains. 6

Dams clearly cause a significant loss of fish. We know dams are the predominant cause because the escapements after fishing are high. It thus appears that commercial fishing is not responsible for recent declines in the runs or that it has at most a minimal effect on the numbers of fish returning for the next fishing season.

To fully understand the effects of dam building on the Columbia since the 1930's, a comparison of the Columbia with other rivers is instructive. Conservationist Oral Bullard states:

5"Nitrogen Peril: Lifeline Tossed To Salmon, Trout," Atlanta Journal and Constitution; 7 May 1972, sec. B, p. 20, cols. 1-4, (A. P. Portland, Oregon.)

GInterview with Junge, Jul. 28, 1974. 
No river in history has undergone so complete a metamorphosis in such a short period of time-from 1933 when work began on Bonneville and Grand Coulee Dams to 1968, when John Day, the eleventh dam to block the Columbia on the American side was completed...

Bullard continues:

...The Columbia River is the central geographic fact of the Pacific Northwest. Development of the river since 1933 has changed the character of the region. It is now the nation's principal source of hydroelectric energy, and supports a growing industrial and agricultural economy?

As a source of power, the Columbia has one-third of the hydroelectric potential of the United States. 8 To develop the Columbia's potential, there has been a rapid construction of dams. In less than four decades the Columbia has been changed from a rushing torrent into a thousand mile lake-like river. Oregonians want both cheap electric power and fish in abundance. In Oregon, various State and Federal agencies are involved in producing both water power developments and fish. Unfortunately, the'lion's share of efforts has gone to rapid hydroelectric development. This rush to development has obviously had a costly side effect-reduction in fish.

\section{COMMERCIAL INTEREST IN THE RESOURCE}

The dwindling of a once abundant fishery has been detailed. Overfishing and the negative effects of dams, including such.problems as predation, direct mortalities to migrants, and supersaturated nitrogen

7oral Bullard, Crisis on The Columbia, Portland: The Touchstone Press, 1968) pp. 16, 113. 1964).

8 Bonneville Power Administration, The Columbia River (Portland, 
have been examined. However, there are other reasons for the conflict

\section{TABLE III}

\section{VALUR OF COLUMBIA RIVER CANNED SALMON PACK}

(In Cases) (Including Stoelhead Trout)

\begin{tabular}{lrr} 
YEAR & TOTAL PACK & VALUE \\
\cline { 2 - 3 } 1883 & 629,400 & $\$ 3,147,000$ \\
1941 & 513,712 & $7,727,984$ \\
1942 & $4,64,401$ & $8,256,445$ \\
1948 & 324,242 & $11,701,000$ \\
1960 & 72,770 & $3,400,598$
\end{tabular}

SOURCE: Delitt Gilbert., Ed., Pacific Fisherman Year Book International. 60 , No. 2 (1962), p. 66 .

over anadromous fish. One is economics-the total pack of salmon. in 1883 was roughly 10 times the size of the 1960 pack. (See Table III). However, the 1960 pack was slightly higher in total capital value than was the 1883 pack. The shrinkage of atailable fish has resulted in high prices for salmon. The attractive price to the seller keeps a proportionately large number of gillnet fishermen interested in commercial fishing, even though some areas of the Columbia have been closed to commercial fishing and harvesting on the Columbia has been greatly reduced. For example, in 1938 there were 1,191 gillnet licenses issued. In 1968 there were 768 , or 65 per cent of the total issued in 1938.9 In comparison, the allowable fishing time has shrounk by 76 per cent be-

9 Fish Commission of Oregon, Washington Department of Fisheries, The 1968 Status Report of the Columbia River Commercial Fisheries, (Portland: State of Oregon, State of Washington, 1969), p. 8. 
tween 1938 and 196810 By 1968 only one fourth of the 1938 catch was taken by fishermen numbering substantially more than half the 1938 figure. The decline of the resource and the high economic value of canned fish have been listed as sources of ill will between fishing interests. Since there has been mach conflict over steelhead it is necessary to examine the decline of these fish to find if there is a greater degree of erosion of steelhead-- and therefore more conflict. By examining steelhead man figures it becomes apparent (Table IV) that the more recent runs are consistently lower. However, when we examine the annual steelhead landings during the period 1938-68, (figure 2) we note that considerably fewer steelhead were caught.

By referring again to $\mathrm{Table} I V$, it is evident that the summer steelhead run is low and the number of winter fish landed (figure 2) is greatly reduced. The summer steelhead must fight their way past additional up-river dams and consequentiy they have a low return per spawner (Table I). On the other hand, the winter steelhead run is less than it once was but the return per spawner is adequate and the run appears to be in good condition, according to Fish Commission Specialist C. J. Junge. I]

10The Fish Commission of Oregon by the adoption of rules establishes fishing time on the Columbia River. ORS 506.141 states: "(I) The commission shall, in compliance with ORS 183, promulgate such rules as it finds after investigation and hearing to be convenient or necessary to prevent the taking, processing, selling or otherwise disposing of food fish at such times or places or in such manner as, in its judgment, will impair the ultimate supply thereof." Fish Commission of Oregon, Administration of Commbercial Fishing Laws-Commercial Fishing and Fisheries (Portland: State of Oregon n. d.) 506.141 . 17.Junge, "Can We Maintain Our Salmon"speech, Jan. 13, 1968, p. 3. 


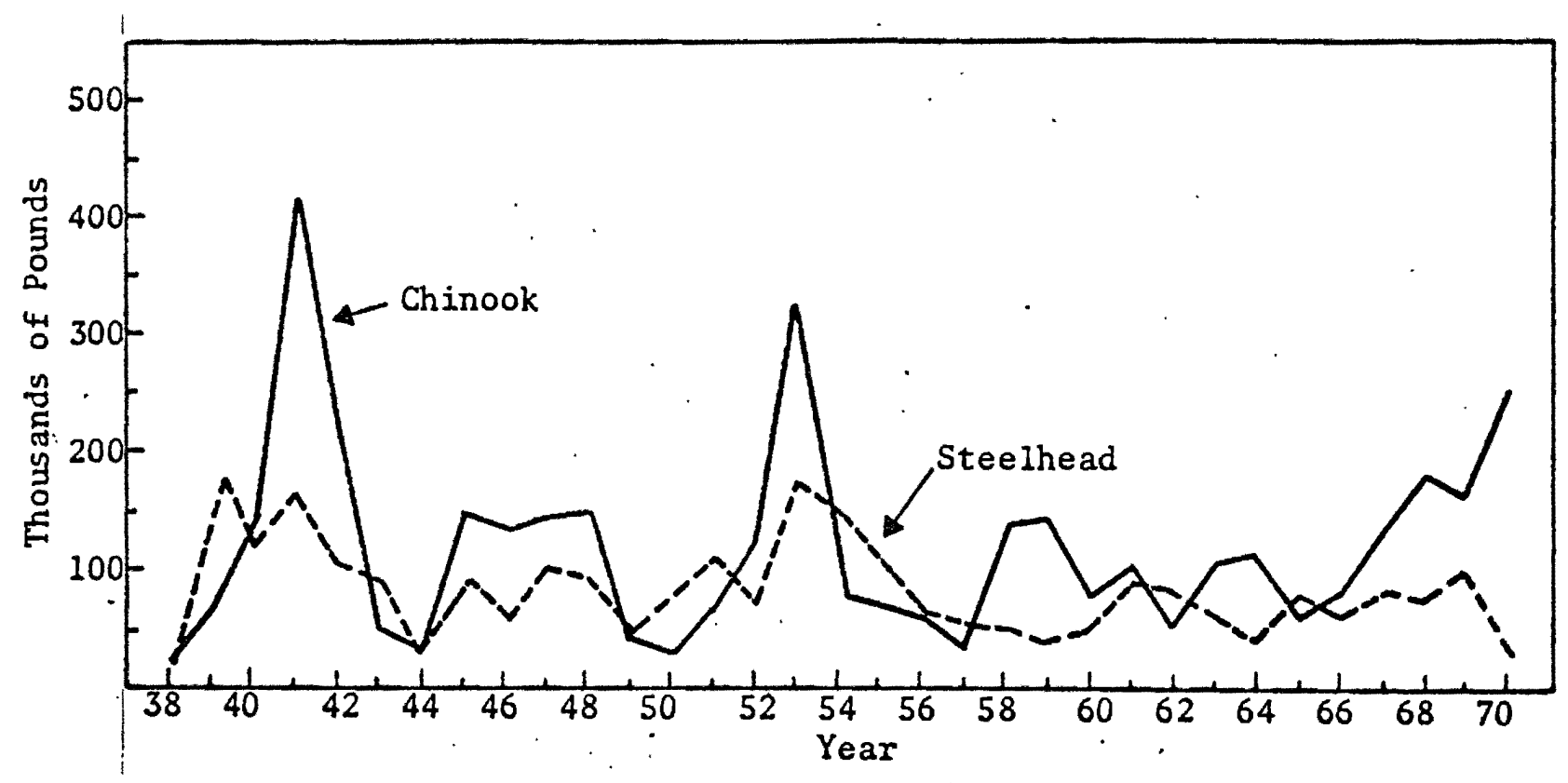

Figure 2 Columbia River winter season chinook and steelhead landings, January- March 7, 1938-70.

SOURCE: Fish Commission of Oregon, Washington Department of Fisherios, the 1968 Status Renort of the Columbin River Commercial Fisharies, (Portland: State of Oregon, State of Washington 1969), p. 29. 
TABLE IV

SUMMER STEEI,HEAD ENTERING COLUMBIA RIVER

Number landed by Zone (Thousands)

\begin{tabular}{|c|c|c|c|c|c|c|c|}
\hline$\overline{Y e a r}$ & $1-5$ & 6 & $1-6$ & $\begin{array}{l}\text { Bonneville } \\
\text { Count }\end{array}$ & Run & \multicolumn{2}{|c|}{ Escapement } \\
\hline $\begin{array}{l}1938 \\
1939\end{array}$ & $\begin{array}{l}143.0 \\
111.0\end{array}$ & $\begin{array}{l}38.1 \\
25.8\end{array}$ & $\begin{array}{l}181.1 \\
136.8\end{array}$ & $\begin{array}{l}106.6 \\
121.0\end{array}$ & $\begin{array}{l}249,6 \\
232.0\end{array}$ & $\begin{array}{l}68.5 \\
95.2\end{array}$ & en \\
\hline $\begin{array}{l}1940 \\
1941 \\
1912\end{array}$ & $\begin{array}{l}239.8 \\
221.8 \\
\end{array}$ & $\begin{array}{l}52.9 \\
54.1\end{array}$ & $\begin{array}{l}292.7 \\
275.9\end{array}$ & $\begin{array}{l}183.0 \\
115.0\end{array}$ & $\begin{array}{l}422.8 \\
336.8 \\
207.2\end{array}$ & $\begin{array}{r}130.1 \\
60.9\end{array}$ & 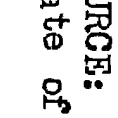 \\
\hline $\begin{array}{l}1942 \\
1943\end{array}$ & $\begin{array}{l}146.9 \\
125.2\end{array}$ & $\begin{array}{l}41.5 \\
31.8\end{array}$ & $\begin{array}{l}188.4 \\
157.0\end{array}$ & $\begin{array}{r}150.3 \\
90.8\end{array}$ & $\begin{array}{l}297.2 \\
216.0\end{array}$ & $\begin{array}{r}108.8 \\
59.0\end{array}$ & 8 \\
\hline 1944 & 134.3 & 42.0 & 176.3 & 98.0 & 232.3 & 56.0 & og \\
\hline 1945 & 153.8 & 38.0 & 191.8 & 114.6 & 268.4 & 76.6 & \\
\hline 1946 & 130.1 & 45.8 & 175.9 & 137.9 & 268.0 & 92.1 & \\
\hline 1947 & 129.4 & 38.9 & 168.3 & 132.4 & 261.8 & 93.5 & \\
\hline 1948 & 103.4 & 43.1 & 146.5 & 136.7 & 240.1 & 93.6 & \\
\hline 1949 & 45.7 & 36.7 & 82.4 & 116.8 & 162.5 & 80.1 & $\phi^{3}$ \\
\hline 1950 & 66.9 & 25.0 & 91.9 & i12.I & 179.0 & 87.1 & \\
\hline 1951 & 104.4 & 37.5 & 141.9 & 140.1 & 244 & 102.6 & \\
\hline 1952 & 123.0 & 57.2 & 180.2 & 260.1 & 383.1 & 202.9 & $\begin{array}{l}50.09 \\
090\end{array}$ \\
\hline 1953 & 139.6 & 65.9 & 205.5 & 221.7 & 361.3 & 155.8 & \\
\hline 1954 & 114.5 & 23.5 & 138.0 & 175.0 & 289.5 & 151.5 & \\
\hline 1955 & 101.7 & 48.7 & 150.4 & 197.1 & 298.8 & 148.4 & \\
\hline 1956 & 71.6 & 27.9 & 99.5 & 129.1 & 200.7 & 101.2 & 0 \\
\hline 1957 & 91.6 & 0.2 & 91.8 & 138.0 & 229.6 & 137.8 & ro \\
\hline 1958 & 80.5 & 4.1 & 84.6 & 130.7 & 211.2 & 126.6 & \\
\hline 1959 & 103.0 & 0.8 & .103 .8 & 128.6 & 231.6 & 127.8 & 교 \\
\hline 1960 & 86.7 & 1.3 & 88.0 & 173.1 & 199.8 & 111.8 & \\
\hline 1961 & 89.2 & 1.5 & 90.7 & 138.7 & 227.9 & 137.2 & \\
\hline 1962 & 88.7 & 0.5 & 89.2 & 163.0 & 251.7 & 162.5 & c \\
\hline 1963 & 100.4 & 8.5 & 108.9 & 128.4 & 228.8 & 119.9 & \\
\hline 1964 & 43.7 & 6.7 & 50.4 & 116.2 & 178.5 & 109.5 & 岗 \\
\hline 1965 & 47.6 & 13.2 & 54.8 & 165.6 & 226.8 & 152.4 & $\frac{\pi}{5}$ \\
\hline 1966 & 36.3 & 3.1 & 39.4 & 142.9 & 208.3 & & \\
\hline 1967 & 25.9 & 15.8 & 41.7 & 120.0 & 166.4 & 104.2 & 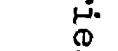 \\
\hline 1968 & 27.1 & 9.4 & 36.5 & 106.5 & 161.4 & 97.1 & $\omega^{\circ}$ \\
\hline 1969 & 21.3 & 14.1 & 35.4 & 139.3 & 180.0 & 125.2 & \\
\hline 1970 & (16.1) & (13.2) & $(29.3)$ & $(113.2)$ & (138.7) & $(100.0$ & d \\
\hline
\end{tabular}


It is likely that the conflict over steelhead is in part due to cutting back on fishing in order to conserve the winter runs and maintain the small summer run. This limited fishing of winter steelhead and the nearly non-existant fishing of sumer steelhead frustrates avid steelheaders, even though steelhead have not declined to a greater degree than other salmanoids.

\section{GROWTH OF THE SPORT FISHERY}

There is more to the angler-gillnetter hostility over steelhead than decrease of the runs and a high price for canned fish. By reviewing the sale of sport fishing licenses, we can observe the growth of sport fishing. In 1965, 276,000 salmon-steelhead sport fishing Iicenses were issued. In 1970, the number was 353,000 , an increase of 28 per cent in five years. 12 Tied to this growth is another factor. Sports fishermen are catching an increasingly high volume of fish. By examining the annual catches of winter steelhead by anglers and commercial fishermen (Figure 3), we see how many more fish are being caught by anglers. The increase of sport-caught fish in 1965 alone is very high. The growth of anglers and the heavy increase in the numbers of fish they catch explains a. great deal of the bitterness over steelhead. There is a high and growing interest in sport fish with a rapid increase in the number of steelhead caught by sportsmen. There are not proportionately fewer commercial fishermen to accompany a diminished supply and curtailed fishing seasons. There are too many fishermen for each fish in the river.

12R. C. Sayve, Staff Biologist Fish Planning, Oregon State Game Commission, to Emery Albertson, 7 June 1972, p. 1. Portland, Oregon. 


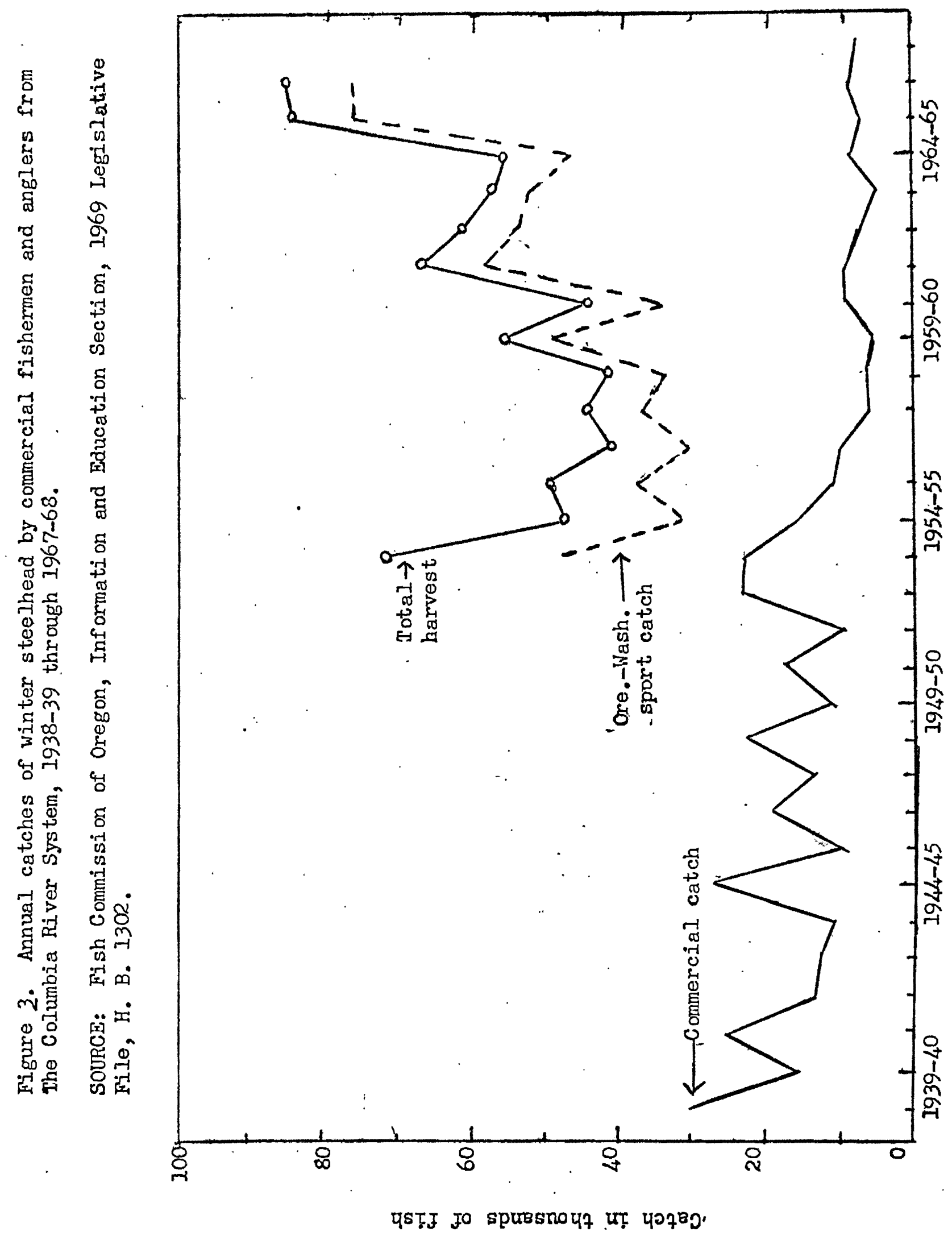




\section{PSYGHOLOGY OF THE CONFLICT}

Hostility between sport and commercial fishermen is but a new varLety of a bistory of ill-will over Columbia River fish. Conflict betwoen fixed and floating gear operators was covered in Chapter II. As indicated, wheels were driven from the river in 1927. Even though they rarely took over 5 per cent of the total yearly catch, they took an immense amount of fish in a short period of time. Fishwheel No. 5 took up to a high of 35 tons per day. 13 Not surprisingly, the hostility from more modest catch fishermen was directed at that time toward fixed gear such as No. 5. Theodore Bugas illustrated the current equivalent to this psychological attitude in his testimony before the House Fish and Game Committee in the 1969 Legislative Session.

We are only talking about one area of conflict as it hits the Columbia River 140 miles long, where for 75 days out of the year, we share this resource. Now, admittedly, a net takes a lot more than a hook. There has never been any contention to the contrary, and it is always going to be this way. It is not going to change, and unfortunately it makes some people unhappy when they are fishing with a hook behind a net - - it makes them unhappy and we are, sorry, but it is still a fact and it's always been a fact.14

The commercial catch is a fraction of the total catch. The food fish caught generally number less than 10 per cent of the total catch, (Table V) but commercial fishermen are a small minority, while sport fishermen are quite numerous. Commercial fishermen find thamselves in

13Domaids on and Kramer, Fishwheels, 1941, p. 7.

Ustate of Oregon, Fish and Game Committee Minutes, 55th Regular Session, (Salem: Oregon State Archives, 1969), Apr. 10, p. 5. 
the same position fish wheel operators were in the 1920 's and the seine and trap owners in 1948. There is a certain amount of scapegoating occurring. As runs deplete, the numerous fishermen look at those who are less in number but who take relatively large amounts of fish in short periods of time. (Dams are the realiy large consumers, but they appear in the background of the conflict and are less assailable.) The psychology of this situation bears resemblance to a common dining room in some respects. If the river could be conpared to a comon mess hall and all the fishermen were diners who contributed to the feast and ato in common, then the situation becomes clearer. A distinct minority eats too much-- takes huge amounts of a decreasing food supply-- they eat too much too fast. The majority of diners are angered. The more numerous "small portion" diners join forces and ban, the minority from the table. The fish fights resemble this situation and the commercial fishermen seem to be the current victims. They are pinpointed for removal by sport interests. Sportsmen are focusing on commercial fishermen When the large consumers of fish are dams. However, the anglers and their conservationist allies are not totally off course. They have legitimate complaints against commercial fishing. . Before HB 1302 became law, the industry's gillnets often took more steelhead than salmon. 15 In addition, commercial fishing also has at least two very negative side effects on sport fishing. John. McKean, Director of the Oregon State Game Commission, pointed these problem areas out in his testimony before the House Fish and Game Committee on April 3, 1969.

${ }^{15}$ Ibid., Mar. 11, pp. 5-6. 
TABLE V

NUMBERS OF WINTER STEELHEAD (IN THOUSANDS)

COLUMBIA RIVER SYSTEM, 1953-54-1970-71.

\begin{tabular}{ll} 
Catch \\
\hline Commercial & Sport \\
Gill Net & (Oregon \\
& and
\end{tabular}

Run Year Wash.)

1953-54

1954-55

1955-56

1956-57

1957-58

1958-59

1959-60

.1960-61

$1961-62$

1962-63

1963-64

1964-65

1965-66

1966-67

$1967-68$

$1968-69$

1969-70

$1970-71$

1971-72

48.2

23.4

16.4

11.6

10.7

6.8

7.0

31.3

38.4

30.9

37.7

6.3

9.6

9.9

7.8

34.2

49.1

34.4

57.7

5.4

9.5

. 8.0

9.0

8.3

12.8

$3 /$

54.1

52.6

46.4

76.6

70.6

3.6

79.0

79.0

1972-73

(4.6)

SOURCE: Fish Commission of Oregon, Washington Department of Fiseries, The 1968 Status Report of The Columbia River Commercial Fisheries, Portland: State of Oregon, State of Washington, 2969) p. 8. 
Mr. McKean noted that commercial nets catch steelhead along with salmon and disperse the runs. Both the quantity and the quality of sport fishing decline, as there are fewer fish left for anglers. This occurs because the nets scatter the fish and result in making steelhead more difficult to catch on a hook and line. Also in the process of catching the relatively larger salmon the prize steelhead (were and still are) taken-even if commercial fishermen canscientiously attempt to keep the steelhead an incidental catch -- the mesh size employed to successfully catch salmon will invariably take trophy sized steelhead. Steelhead put up a magnificent fight on a hook and a line - and that's what makes sport fishing so thrilling for anglers. When a sportsman catches a large steelhead he experiences the psychological equivalent of a hunter taking a large deer or elk. 16

The conflict between sportsmen and commercial fishermen appears unavoidable. Salmon fishing means a certain incidental catch of steelhead and a reduction in quality of sport fishing for sportsmen as long as the commercial fishermen exercise their traditional right to fish. Consequently, the conflict continues and each side attempts to justify its position. Quite understandably, the commercial industry feels threatened by attacks from sport fishermen. The commercial fishermen and their allies know they have fished for approximately a century for profit, and they usually take less than 10 per cent of the runs. They feel that sportsmen are out to unjustly drive them off the river. However, no matter how correct the commercial fishermen are in their feelings, the

16Walter McGovern, (former) Oregon President, Northwest Steelheaders Council of Trout Unlimited, interview held on the telephone, Portliand, Oregon, 13 Nov. 1972. 
sportsmen are not the only ones to behave largely on emotion and strive to foreclose another's right to fish. The commercial gillnet industry joined with sportsmen in 1948 to ban trap and selne operators from the river. Indeed, the gillnet industry was the main power than (as the sport groups are a relatively recent political phenomenon.)

Also, the gillnet industry gave no quarter when it drove fish wheels from the river in 1927. The fish wheel operators and the trap and seine fishermen had a traditional right to fish that was as old as the beginning of white settlement commerce on the Columbia.

When gillnet operators joined forces with the sportsmen in 1948 , sport fishing was a political "baby". Now the bear which the commercial industry helped to $\mathrm{grow}$ is beginning to bite. The gillnetters complain because the bear is biting them for the same reasons-a situation often justified by arguments similar to those the net fishermen used against the fixed-gear operators. 
CHAPTER IV

PASSAGE OF HB 1302

PRIOR TO THE HEARING

In Chapter II it was noted that Governor Tom McCall and his Administrative Assistant Kessler Cannon met extensively with sport and commercial groups from 1967 through 1969. The meetings were marked by friendly attitudes on the part of members of both camps. However, as the 1969 Legislative Session approached, the mood of each interest group changed. The sport groups took the attitude that "not one fish" should be taken by gillnets. The industry's stance was also rather rigid. Packers were reluctant to even consider steelhead as a game fish since they viewed this or any other "compromise" as a further whittling away of their interests. 1

Early in the 1969 Legislative Session, Representative Connie McCready was approached by officials of the Izaak Walton League, the Pacific Northwest Association of Steelheaders and the Oregon Wildlife Federation. These sport fishing interest group representatives wanted McCready to introduce legislation that would make steelhead 'a game fish and prevent commercial catches of this rainbow trout. A basic proposal for such a bill was worked out by Representative McCready and the representatives of the three organizations. It provided for designation

1Kessler Cannon, (former) Administrative Assistant Department of Natural Resources to the Governor. Pwo interviews held at the State Capitol, Salem, Oregon, Oct. 14, 1969 and Jul. 26, 1972. 
of steelhead as a game fish and harsh penalties for commercial catches of steelhead.

Representative McCready took the proposal to the Iegislative Council for bill drafting. Council staff advised simple amendments to the definition of game fish under the game code. Also, staff suggested that the definition of salmon in the commercial fishing law needed amending. The proposed bill named steelhead as a game fish, repealed the incidental catch law by deleting steelhead from the commercial code and provided stiff penalties for taking steelhead. It was sent to. Connie McCready on January 24, 1969.2

After the bill was drafted McCready requested and received written support for it from the three sport organizations. 3 . Her next step was to gain support from Senator Eivers from Clackamas County, who represented a strong sport fishing constituency. Finally, the bill's sponsor acted to obtain bi-partisan support for the bill. She knew from bitter experience that cross party support for HB 1302 was essential.

The first reading of $\mathrm{HB} 1302$ was on February $8, \cdot 1969$. The next day, the bill was referred to the House Committee on Fish and Game. 4 On February 26, 1972, the director of the Oregon State Game Commission, John McKean, stated that some provision for disposal of steelhead

2Connie McCready, (former) Oregon State Representative, District 6, Multnomah (East Central) interview held at her home, Portland, Oregon, Aug. 4, 1969.

3She asked for written support because in the previous legislative session sport fishing organizations had given verbal assurances of their support for a steelhead bill. However, one of the groups had subsequently withdraw its support during the legislative session. (Ibid).

4state of Oregon, Journals and Calendars of the Fifty-Fifth Iegislative Assembly, Regular Session. Beginning January 13 and ending May 23. 1969, (Salem: Oregon State Archives, 1969), p. 719. 
trout accidentally caught by commercial fishermen was necessary. He felt that the bill was rigid and unworkable because the potential statute would make the incidental catch of any steelhead with salmon illegal. He sent a suggested amendment to Representative McCready on February 27, 1969. The amendment allowed for an incidental catch of steelhead. The catch was to become property of the state. The fish were to be disposed of through public institutions and would be treated in the same manner as out-of-season deer. 5

THE COMMITWES HEARING

The first committee hearing on HB 1302 was held on March 11, 1969. The major groups supporting the bill were the Pacific Northwest Association of Steelheaders, the Oregon Wildlife Federation and Izaak Waltion Ieague. The groups against the bill included the Columbia River Salmon and Tuna Packers Association, the Lower Columbia Fishermen's Protective Union and the Amalgamated Meat Cutters and Butchers Workmen of North America (AFI-CIO), Local Number P. 554.6

These interest groups all testified and expressed their views on House Bill 1302 .

(Summaries - including paraphrasing and quotations of the most important individuals and group testimony follows).

Representative Connie McCready, HB 1302's sponsor, stated the bill would aid in ending the user conflict on the Columbia River. She indicated the average annual (winter season) catch from 1967-1969 was 5,000

5John McKean, Director Oregon State Game Commission, to Steelhead Committee, Portland, Oregon, Feb. 27, 1969.

6state of Oregon, Fish and Game Committee Minutes, 55th Regular Session, (Salem: Oregon State Archives, 1969.) Mar. 11, p. 1. 
chinook and 7,700 steelhead. She questioned whether the steelhead catch was truly incidental. Obviously, the individual catch provision in the law was not working. McCready stated that steelhead are game fish -"Anyone who's caught one - - anyone who's watched on being played - anyone who's lost one - - will never dispute that fact." McCready noted that Washington and Idaho have long distinguished steelhead as a game fish. The recognition of steelhead as a game fish by Oregon's sister states produces a problem. Oregon is out of step with Washington and Idaho. The state of Washington has proposed legislation to deny outof-state fishing licenses to Oregonians until steelhead becomes a game fish in Oregon. In addition, the state of Washington had (in 1969) another proposed bill that would raise the license fee for Oregon sport fishermen to thirty-five dollars, while leaving other out-of-state license fees at fifteen dollars. These bills were introduced in the Washington legislature because Oregon had refused to recognize steelhead as a game fish. Representative McCready also mentioned the hostile acts of Washington anglers. Some sports fishermen in that state had slashed the tires of Oregon sportsmen while fishing in Washington. These destructive acts were the result of hostility over steelhead. Many sportsmen in Washington feel that the State of Washington raises steelhead to be caught by Oregon's gillnet industry.

McCready also answered the commercial allegation that reduction of . the gillnet catch would waste the resource. She cited the case of the Alder River in Norway. Sport fishing is excellent on this river. None of the fish are harvested commercially; consequently, there is an abundance of fish for sport fishing. However, a fishing trip on the Alder River would cost approximately five thousand dollars. Management of the Columbia for 
commercial harvesting (sustained yield) hurts the poorer citizen. The wealthy individual can buy access to private or remote areas such as the Alder River in Norway. If the Columbia River steelhead runs were managed for sport fishing, the poor man could have access to good recreational fishing. 7

Ted Bugas, The Executive Secretary for the Columbia River Salmon and Tuna Packers Association, presented prepared testimony for the Association, the Lower Columbia Fishermen's Protective Union, and the Amalgamated Meat Cutters and Butchers Workmen of North America, (AFI-CIO), Iocal P. 554.

Bugas said that his industry urged the committee not to approve HB 1302. The proposed bill would further restrict a tightly regulated industry in Oregon. There is no justification for the reduction, as indicated by the scientific facts gathered by the agencies charged with the management of the commercial fishery. These agencies have repeatedly stated that the stocks of winter steelhead are under-utilized. Their figures show that sport fishermen and commercial fishermen, in both Oregon and Washington, have in the past six years averaged only about 70,000 fish out of an estimated 220,000 . The fish caught are less than one-third the total for the winter runs of steelhead.

As for the summer steelhead, the runs are in rather poor condition, but not because of fishing. The summer run is doing poorly largely because the fish must move farther upriver to spawn. The dams have adversely affected summer steelhead since the fish must go through these obstacles to reproduce. However, this run is protected by the state.

7. 
Mr. Bugas explained that his industry understands and supports restrictions based upon the preservation of the ultimate supply. But this bill would have many negative effects. Its passage would eliminate over 50 per cent of the industry's present fall salmon season, and therefore would damage the commercial fisherman. It would harm the economy of the state as thousands, and perhaps even millions of pounds of other species of salmon could not be taken if HB 1302 became law. Bugas went on to explain that the industry would have been prohibited from catching most, if not all, of the eight million pounds of the two greatest coho salmon runs on the Columbia (in recent history) if the bill had been law at that time. By allowing the steelhead which are intermingled with coho to escape, escapement of both fish species results since they are similar in size. Bugas went into more expalanation concerning nets. Even the larger mesh nets used to take salmonoids commercially do capture some smaller fish. Thus, this measure which absolutely prohibits commercial fishing of steelhead would be violated every time a steelhead was taken.

The purpose of the bill is to provide for exclusive desigmation of steelhead in Oregon as game fish. The important word here is "exclusive", because historically steelhead has not been exclusively a game fish. Ever since the original Indian fishery steelhead have been taken both for food and for sport. It has never been the aim or desire of the commercial industry to make this fine food fish exclusively a food fish. Commercial fishing has never tried to prevent steelhead's joint use and enjoyment by sportsmen. Yet the legislature deliberates whether or not sport steelhead fishermen, who are taking an ever-larger percentage of these fish, have the right to prevent any joint commercial use of them. Bugas stated that continuous support has come from the Association of Northwest 
Steelheaders, a group of sport fishermen dedicated to fishing for steelhead and eliminating commercial fishing. Bugas reminded the committee members that just last session, in the same room, before the same committee, Kenny Gates, a past president of the Pacific Northwest Association of Steelheaders and an outspoken sportsman, appeared as a witness. Gates had stated that, after the resounding 1964 vote that struck down a sports initiative that would have barred commercial fishing for salmon and steelhead on the Columbia, he recognized that there was no chance to eliminate in a single stroke all commercial fishing on the river. Bugas emphasized that Gates openly stated that the sportsmen would continue to try to get their goal accomplished "a little piece at a time." Bugas said that this bill was part of that effort. Gates and his organization would not be happy until all commercial fishing were eliminated.

Bugas noted that most sportsmen in Oregon know of the contribution of the commercial industry to the preservation of the salmon resources of the Northwest. The majority of sportsmen know that the industry consistently fights for fish passage facilities on the Columbia, against pollution, and for continuing support for salmon managment and research agency budgets at both state and federal levels. Consequently, most sportsmen are aware that no one has as much to lose by the practice of inadequate conservation as do the commercial fishermeni. Most sportsmen realize that the industry is not only compatible with sound conservation but is in fact a supporter of the resource's development. Most sportsmen are willing to leave the management of the resource to the experts in the management agencies. He also mentioned that the majority of sportsmen must have voted with commercial fishing because the total number of votes in favor of elininating commercial fisking was less than one-third of the total 
number of hunting and fishing licenses issued in Oregon that year. Over 72 per cent of the voting populace of Oregon voted against the 1964 measure on the ballot. Mr. Bugas concluded by stating that commercial fishing personnel believe that Oregonians will again support the commercial industry against this measure which is not founded on good conservation. 8 The Izaak Walton. League spokesman stated that making steelhead a game fish, with a disposal clause as suggested by the Game Commission, will result in (1) uniformity in the classification between the border states on the Columbia River, and (2) great economic benefit to the state of Oregon by recognizing the highest and best use of steelhead-mecreational fishing. 9

The Oregon Wildlife Federation urged passage of HB 1302 to finally resolve the senseless conflict between the people and the states that share the Columbia River and to insure for the people of the state the greatest recreational and economic benefits from the resource. 10

The Pacific Northwest Association of Steelheaders spokesman expressed the group's concern that Oregon had not kept faith nor been in step with other states. However, with this bill Oregon would have a better relationship with other states. Also, HB 1302 would provide a sufficient recreational fishery for the ever-expanding numbers of Oregonians who are interested in sport fishing. 11

8Ibid., Mar. 21, Exhibit C, pp. 1-8.

IIbid., Mar. 11, Exhibit B, p. 4.

10 Ibid., Mar. Il, Exhibit D., pp. 2-3.

IIIbid., Mar. 11, p.6. 
George Hibbard, Chairman of the Game Commission testified in support of House Bill 1302 and gave to the committee amendments suggested by the Game Commission. In addition, he presented memorials (requests) from the legislatures of Washington and Idaho. These memorials asked Oregon to make steelhead a game fish.

In his testimony, Hibbard noted that Oregon has over a half-million licensed anglers. These sport fishermen are important -- their interests concern the state of Oregon. Also of concern is the conflict with the people and programs of Washington and Idaho. Both these states classify steelhead as a game fish. The state of Oxegon's concept that the supply is adequate to justify a commercial fishery jeopardizes their programs for propogation and protection of the species in the Columbia Basin streams. Hibbard stated that the memorials conveyed the concern of legislators and citizens of these neighboring states.

He stressed that the economic value of the Oregon steelhead sport fishery cannot be over-emphasized. Based on punch card estimates for 1967, Oregon anglers took 134,040 steelhead of which 55,676 or 41 per cent were taken from the Columbia River and its tributaries in 208,785 trips by anglers. Comparison of the expenditures of steelhead anglers with the retail value of commercially taken steelhead indicates that people are willing to pay nearly three times as much for the sport of steelhead fishing (per fish) as those steelhead caught commercially.

A national survey of fishing and hunting conducted by the Bureau of Sport Fisheries and Wildlife in 1965 showed that anglers spent an average of approximately five dollars per trip. This figure has been revised by the Bureau of Sport Fisheries and Wildlife to six dollars per angler trip. An expenditure of $\$ 1,252,710$ was made by Oregon sport fishermen alone in 
Columbia Basin steelhead fisheries in 1967. They spent this sum to catch fifty thousand fish. Expressed another way: each steelhead cost $\$ 22.50$ per angler. This $\$ 22.50$ per fish is of far greater value than the retall value of commercially marketed steelhead--approximately $\$ 1.00$ per pound. Hibbard stated that the Game Commission recommends classification of steelhead as a game fish. The Commission also recognizes that some steelhead will be taken during authorized net fisheries for salmon or other food fish. 12

Kessler Cannon, Administrative Assistant, Department of Natural Resources, to Governor McCall testified in support of legislation to make steelhead a game fish. Cannon stated, "It seems that it is time to resolve the issue and for this legislature to pass legislation to accomplish this basic purpose, thereby setting a policy in managing the commercial fishery to minimize the catch."

Mr. Cannon noted that Oregon is at the point where management policy cannot be based on technical knowledge alone. This is a public policy issue. The issue is the best use of the resource. Is it in the public interest to make this a single use resource--a game fish?

The Governor's assistant said that he wanted to emphasize the governors of the states of Oregon, Washington and Idaho and the five managements within the three states are on record in favor of a healthy commercial fishery. Cannon concluded by stating that the most difficult decision will concern the incidental catch. He stated the hopes of the Governor that the Legislature would make steelhead a game fish. 13

12Ibid., Mar. 11, Exhibit A. pp. 1-3.

13 Ibid., Mar. 11, Exhibit A. pp. 2-3. 
PROPOSED GAME COMMISSION AMENTMENTS

On April 3, 1969, the House Fish and Game Committee held its first work session on $\mathrm{HB}$ 1302. The entire committee of nine members was in attendance: Rod McKenzie (Chairman), Wayne Turner (Vice-Chairman), Fred Heard, Connie McCready, Allan Pynn, Gerald Detering, Robert Dugdale, Grace 0. Peck and George Cole.

The committee's major witness was the Director of the Oregon State Game Commission, John McKean. He explained the amendments proposed by the Commission. These amendments provided for an incidental catch of steelhead by the commercial fishery. However, any steelhead caught incidentally would be state property. The fish would be disposed of through public institutions. Thus, steelhead would be treated similar to out-of-season deer. McKean explained that the processor, the buyer and possibly some commercial fishermen would be compensated for the trouble of delivering the fish. McKean stressed that the major objective was to take the profit motive out of fishing for steelhead. 14

Next, the value of steelhead as both game and food fish was discussed: The exchange between McKenzie and McKean clearly indicates the stand of the Chairman:

John, I can't help but get the feeling that -- (word inaudible) is to do away with commercial fishing entirely-- I saw a group of people in front of the building one day all the signs weren't just for steelhead. .

I can visualize fish unlimited with modern technology if we were all going the same way--I've seen you people come together a long ways [sic] in the past couple of months. Ranny and Joe Holmstrom, I haven't seen them put their arms around one another but I've seen them speak. Irast session, I didn't see anybody speak to anybody. I was expecting to see them looking down a rifle barrel. . . 15

14 Ibid., Apr. 3, pp. 1-2.

15Henry Rancourt of the Wildilife Federation and Senator Holmstrom, a comercial fishing supporter. 
McKean: I think their concept is a social and psychological problem that we have, it proposes an amendment to get the thing done that you're talking about. The steelhead is not a good commercial fish anyway, and we could manage it as a game fish and perhaps even more can be done for making more salmon. . .

Chairman McKenzie: It appears that just giving up the steelhead is not going to stop this continual warfare between the commercial fishery and the sports fishery. . 16

McKean: Mr. Chairman, I might point out that so far as demand is concerned, we have a growing demand and the percent of steelhead fishermen are increasing about 5 per cent a year and statistically, we have records that indicate that there is a significant need for it-- by both the [sic] particularly in fishing pressure. As soon $2 s$ commercial season opens in the Columbia, the sports fisherman's efforts are knocked way off. This is no doubt largely a product of their success and it might be a psychological thing... The fact remains that it does particularly cut off the sports fishery. 17

In response to a question by chairman McKenzie, Cambell (McKean's assistant) stated:

One of the major sports fisheries is on the Columbia River, the main stems [sic] below Bonneville and we have a very--(word inaudible) in the last 2 or 3 years on that and this does show quite extensively that the pressure drops off very greatly when the nets go in during the commercial seasons on the river. The catch per input of effort doesn't drop as much, but the size of the fish that is caught drops considerably. Instead of catching fish a large percentage over 20 inches the percentage of that size becomes much less, merely because the nets do take the larger fish. 18

After covering these subjects, the discussion focused on the value of the food fishery.

Representative Heard: What about the total dollars as far as the cannery. is concerned? 19

$$
\begin{aligned}
& { }^{16} \text { Ibid., Apr. 3, p. 8: } \\
& { }^{17} \text { Ibid., Apr. 3, p. 9. } \\
& { }^{18} \text { Ibid., Apr. 3, p. 9. } \\
& { }^{19} \text { Ibid., Apr. 3, p. } 11 .
\end{aligned}
$$


Bugas answered Heard by stating that the commercial industry employs and pays for roughly 650 working days per year to pack the fish. This figure does not include the labor of the fishermen. The price for steelhead fluctuates and is approximately thirty-five cents per pound during the winter and twenty-five cents in the summer. Wholesale price is about $\$ 24.50$ for a forty-eight can case of $3-3 / 4$ size cans. Shelf price ranged from forty to fifty-five cents per can. The industry generally handles about 450,000 pounds of steelhead in an average year. 20

The major themes of the legislative debate on the fish issue became evident during the first work session of the House Fish and Game Committee. For example, game fish proponents were noticeably unconcerned about any Iosses or damage to commercial fishing that might be caused by the designation of steelhead as a game fish. Rod McKenzie, the Committee Chairman, had implicitly stated his views.- "couldn't help but get the feeling that-(word inaudible) is to do away with commercial fishing entirely".21 McKenzie also voiced his interest in increasing propogation to provide more fish for everyone. Representative Heard questioned the effects on industry and the loss of jobs resulting from a reduction of the commercial steelhead catch.

Commercial lobbyist Ted Bugas' statements revealed the industry's tactics concerning the issue of economic impact. Instead of emphasizing dollars, the industry lobbyist stressed the value of jobs. Bugas stressed this value throughout discussion of the proposed legislation.

20Ibid., Apr. 3, pp. 11-12.

21Ibid., Apr. 3, p. 8. 
On April 8, the House Fish and Game Committee held its second work session on $\mathrm{HB}$ 1302. The major testimony considered by the committee was given by Robert Schoning, Director of the Oregon Fish Commission. His testimony concerned the state's hatchery program, its function and needs. The major consideration was the cost of steelhead rearing. Committee Chairman Rod McKenzie asked questions concerning the total cost of raising steelhead and the dollar cost per fish. 22

In a letter to the committee dated April 1, 1969, Schoning had noted that each steelhead taken would represent an investment by the state of approximately $\$ 2.60$. He stated that the winter runs in the lower Columbia averaged approximately 200,000 fish. The commercial fishery averaged 8,200 fish from the run per season and the sport fishery 55,900 fish. 23

POSITION STATEMENTS-- HEARD AND BUGAS

On April.10, the House Fish and Game Committee met for the third work session. The major activity was a speech made by Representative Heard concerning a possible compromise by the commercial industry. Heard's comments, as well as many of Ted Bugas' statements in reply follow:

Representative Heard: Mr. Bugas, I would like to preface the question I am going to ask, first by saying, that coming from the county. that I come from--certainly this is not an emotional issue there--and however I vote today will be a vote that has no. emotional issue involved -and no political considerations involved, and as I told Mrs. McCready before the meeting, I've received one telegram and one letter from my county.... Iast night I spent most of the night, reading the

22Ibid., Apr. 8, pp. 1-15.

23Ibid., Apr. 3, Exhibit B. pp. 1-2: 
testimony that has been given on this bill since we've first started hearing it, and it seems to me that it is like a set of scales-on one side--the commercial fisheries, you have an industry in the state--don't think we are in a position where we can simply drydock industries when, [sic]. Also, I think the job consideration is very important and I think there is some doubt in [sic] the jobs that wil] be involved, and I think it is a very important consideration and certainly, as a representative of the people. I must consider it. On the other hand, on the other side of the scale, we have the sport fishermon, they pointed out in their lottars, thay havo a possibility of increased... (word inaudible) and we have the enjoyment that so many. sport fishermen have received from this sport.

I don't think that necessarily we should be guided by the actions of some of our neighboring states. I think we primari$\mathrm{ly}$, as representatives of the people of Oregon, have to consider the best interests and good of the people of this state, which is really as far as I am concerned the reason for my vote. The other thing that has come out in the letters from the sports people is the possible damage to this resource and I think it has been pointed out in the testimony at the last meeting of the committee, that as far as damage is concerned, there is no damage.

So these are some of the points that I have considered in attempting to arrive at a decision, and now I have a question I'd like to ask which in a large measure will influence the final way that $I$ vote, and that is, I understand that commercial fishermen have considered the possibility of some kind of compromise that would be beneficial to the fishermen [sic] and to the sports fishermen and to the commercial fishermen--and this compromise that you people are prepared to propose--this would be... to both parties and I think I could reach a fair vote. At this time I would like to ask you what kind of compromise the commercial people are interested in.

Chairman McKenzie: I didn't know there was such a proposal.

Mr. Bugas: Frankly, I think that there is possibly not a proposed compromise in the terminology Mr. Heard uses. I have discussed this matter, of course, with individual members of the committee outside the formal committee hearings, and I have mentioned the fact that I feel that our industry is in a mood to try to resolve the problem. Now, as far as compromise goes, I would like to answer in a very circuitous manner. To begin with, Representative Heard, let me say, if I may, that in the view of our industry, your analogy of weighing it on scales breaks up a little bit in that I don't think this is a case of choosing between the commercial and the sports industry. The commercial industry does not advocate any curtailment of it [Sic] we would like to see it continue to grow. We don't advocate any curtailment, except in the interest of a given run or a given portion of a run of fish. In this case, of course, every- 
body should be entitled to the fish, and we have never come before this legislature, nor have we initiated any kind of legislation curtailing sports fishing. You are not considering, ladies and gentlemen, a situation where you have to choose between the commercial industry and the sports fishing.

It is not our contention, although it has been considered by some, we think some rather biased views in the sports fraternity, to be a choice--either get rid of the commercial fishing in the Columbia River or we will get rid of the sports fishing. This isn't the case at all. It isn't what we advocate, and the more mild and... (word inaudible) people, I believe, in the sports fraternity, and I think by far the majority, Mr. Chairman... do not believe this. The continuing of the runs and the regulation of the commercial fishing precludes our eliminating any fishing--our... (word inaudible) fishing. We are tightly restricted. Again, I say it to the point of triteness, our industry has given birth to the agency which regulates it. The commercial industry saw in the early days of this century, the need for a regulatory agency run through the state, and we insisted that before this legislative body--predecessors of you gentlemen and ladies--that a regulatory agency so established to regulate us because we knew we had greedy individuals--just as you have greedy individuals who are sports fishermen.

And you had a conflict back then much more complex than you have now with various types of gear. You had the seniors [sic] who wanted all the fish, you had the gillnetters who wanted them, you had the wheel operators who wanted them. Mrs. Peck mentioned these [sic] several times. Now we do nct advocate the eradication or curtailment of the sports fishermen-you don't have to choose. On this bill or any other in this legislature, it is our contention that you can have a good, healthy, viable commercial fishery, closely regulated by the Fish Commission as it now is and even more closely as our numbers grow-as population grows-and still continue to have a growing, healthier, even more healthy than it is now, sport fishery, that is...

To come more directly to the point that you want to discuss, Representative Heard, we have resisted--and I have testified earlier-we have resisted compromise for the sake of peace, because we think this is a loser. There is no way for a mutiny

[sic] to be satisfactory to a fiahing hassle on the Columbia Rivor any more than thoro was on the coastal streamo. Rotronchment, retreat out of the coastal streams and cut back of seasons, elimination of certain gear, hasn't stopped the fighting. History is clear-the record is clear. Now we hear an argument this year; just give us steelhead and we will be happy--that will terminate this controversy.'

I say to those who think like this in all sincerity, I respect your attitude, I respect what you think in this regard, but I simply disagree and I think, the facts are with me. Now, 
we have been squeezed out in [sid] utilization of steelhead, and have utilized this commercialiy, many, many more years than any sportsman has. The Indians before us [stc] as food fish. We have been squeezed out to the point where we now utilize-in the three main steelhead states of the northwest, in this country whoro wo aro talking about the problom wo [sic] havo talkod timo and again.

The steelhead is a game fish in Washington, it is a game Pish in Idaho; therefore we should make it a game fish. I don't argue that right or numerical totals necessarily makes for correctness--it isn't necessarily so in efficiency or any other way, but nevertheless, with regard to these three steelhead states, the sportsmen take a total of over five times the number of steelhead the commercials do in Oregon...

We are only talking about one area of conflict as it hits the Columbia River 140 miles long, where for 75 days out of the year, we share this resource. Now, admittedly, a net takes a lot more than a hook: There have never been any contentions to the contrary. And it is going to be this way. It is not going to change, and unfortunately it makes some people unhappy when they are fishing with a hook behind a net--it makes them unhappy and we are sorry.

But it's still a fact and it's always going to be a fact-But essentially you have the steelhead a game fish in Oregon now; you have it by law in Washington; you have it de facto in Idaho-you don't have any commercial industry--no conflict. Now, the point of income, what happens if we make it an, absolutely by-(word inaudible) by law as proposed in $\mathrm{HB}$ 1302, we make it a game fish. I respectfully resubmit for your consideration that you will do a couple of things.

You will, under the law, before it was amended, and less so now that it is amended (you will allow an incidental take under this amendment). But it's totaliy unsatisfactory because you strip a man of the fruits of his labor--it is no more realistic to take away the fruits of a man's labor if he catches that fish by net than it is to take away half of the steelhead... And [Sic] by punch card. We can't expect human nature to suddenly change its whole being by the enactment of such legislation--it isn't going to happen. With the amendment it is equally unacceptable-it does not make the bill quite so [sic], it does make the bill-the bill is absolutely intolerable because it could stop the river elimination of all fishing...because the steelhead swim, freely move, with the other fish on the Columbia River.

But you take away the fruits of a man's labor and to get the steelhead to the state for no compensation--it's almost as untenable to this [s.j] Iish. Now, let me go back again to your point of discussion, Representative Heard. Here we recognize that the commercial industry does not have a majority or [sic] 
now has a relatively small percentage--we have been squeezed down to a relatively small percentage through regulation of other species, except for the winter session. Winter run steelhead have been taken away from us...--no need--simply the conflict that we are now again reconsidering. The steelhead resource in the winter is under-harvested. That is a fact attested to by the scientists before me. Now, let's talk about then, what there is [sic] more to take away from the commercial men.

In the last several years, of all the steelhead that entered the Columbia River, the commercial industry took on the average, approximately 10 per cent--one or two out of every ten that entered the river. To us that looks like a pure incidental percentage of the total run of the river. Still we recognize that majar users of the steelhead now-a-days are the sportsmen. We have an industry that has grown in the use of sportsmen [sic] The sports use of our salmonoids, and I by no means subscribe to the theory that they are the only ones involved really. You gentlemen and you ladies will see more legislation here attempting to further curtail commercial fishing--next session or not, we come to some kind of conciliatory position of this particular measure--I'm sure of it--you know in your own hearts-I talked to a gentleman in the hall the other day who said, look, this is fust another jump. This was six or eight days ago-I'll name him if you want, but the facts are he was here; this is what he wants; this is what a number of rather violent sports fishermen want.

We know it, yet we still recognize that economically we are squeezed down to a point when it becomes questionable how long we can continue to sell, with relatively few food fish. With this we are willing to talk about reasoning. I submit to you, ladied and gentlemen, that when you talk about reasoning--talk about a percentage of the take that can be allowed the commercial people, if we get to this point, or in some fashion consider this--that [sic] you throw out the small, thin, relatively few loud sportsmen who can be appeased in no way. but with the extinction of the commercial fisherman, because under his conditions [sic] with this demand that we get off the river completely, we have no alternative but to say to you "Let us fight".

You have the power in this Legislature to put us out of business. It can be done. You can start the ball rolling right in this committee, and you may do so, I don't know. I am asking you not to. I am telling you that I think we have no possibility of eliminating the conflict of hunters, as long as farmers own land and deer live off the land and hunters hunt the deer. 24

${ }^{24}$ Ibid., Apr. 10, pp. 1-6. 
Representative Heard's statements and questions and lobbylst Ted Bugas' responses reveal much of both the position of the "swing member" of the committee and Bugas' approach to Heard. Bugas' position, and the 1ndustry's tactics, emerge from studying these statements. By analyzing the statements of Heard and Bugas, we gain some insight about their respective positions.

Representative Heard's comments and questions reveal his concern for a "balanced scale" use of the fish resource. He indicated his desire to avoid drydocking the industry. He called this a "very Important" consideration. On the other side, he noted sports fishermen have pointed out in their letters to him the importance of sport fishing. Heard mentioned the enjoyment the sport fishermen have, and it is obvious that this much of the sport fishing argument was recognized by him. He did not mention the fact that sport fishing drops off when the gill nets go into the water, or indicate the relatively large amount of money spent on this sport and the jobs created by such expenditures. Apparently this part of the sports argument was not a factor in shaping his thinking. Because Heard appeared to be thinking of sport fishing only in terms of angler enjoyment, it appears likely that he did not understand or accept the economic argument for sport fishing. There is no persistent, persuasive, low-key effective sport lobbyist to counterbalance the efforts of Ted Bugas. Heard's statements appear to reveal his awareness of the commercial industry's arguments but not those of the game fish proponents. 
Heard asked the industry to explain the proposed compromise:

So these are some of the points that I have considered in attempting to arrive at a decision, and now I have a question I'd like to ask which in a large measure will influence the final way that $I$ vote, and that is; I understand the commercial fishermen have considered the possibility of some kind of compromise that would be beneficial to the fishermen and [sic] to the sports fishermen and to the commercial fishermen--and this compromise that you people are prepared to propose [sic] this would be . . to both parties and I think I could reach a faix vote. At this time I would like to ask you what kind of compromise the commercial people are interested in. 25

Chatrman McKenzie then said he was not aware of any compromise proposal. Bugas answered by saying that there was not. a formal proposal as such. Bugas then mentioned that he had discussed the matter inside and outside committee hearings with members of the committee. He then went on to say that his industry was in a mood to try to resolve the problem. Here we may assume Bugas had expressed his reasonableness in his lobbying activities with Representative Heard. It is understandable why Bugas would not say there was a formal compromise as such. McKenzie, as chairman of the committee, was vitally interested in any proposed compromises. Bugas' answer indicated on one hand he hadn't kept McKenzie in the dark--there was no formal proposal--on the other hand there was reason for Heard to see the possibility of a compromise in Bugas' past meetings. with Heard, i.e. Bugas' statement of his reasonableness.

Bugas answered Heard's question in a long, circuitous way. He did this to accomplish his ends--the circuitous. way gave Bugas ample time and opportunity to answer Heard's question about a compromise after presenting his industry's stand in a very favorable manner, while 
simultaneously slighting any strong sports position, Bugas' reply to Heard contained several items of interest. It revealed much of the industry's view and position, presented persuasively, as well as a view of his tactics.

Bugas first treated Representative Heard's question regarding a compromise. He said:

- . In the view of our industry, your analogy of weighing it on scales breaks up a litt le bit. In that I don't think it is a case of choosing between the commercial and sports industry. 26

The commercial lobbyist had innoculated Heard's idea of choosing between interest groups, without offending or even appearing to offend Heard, who was. the swing vote. The industry lobbyist then went on to show how the industry was not trying to harm sports groups-- "We would like to continue to see them grow."27 Ted Bugas continued to show how legislators do not have to choose- they can have both. Bugas reminded the legislators that his industry had been around since the Indians caught food fish. He pointed out how his industry had been squeezed down to the point where it could retreat no further. The industry emphasized the fact that it had been forced to give up coastal streams--all to no avail--the controversy remained. Bugas referred to the history and the inevitability of the controversy and suggested how a compromise could be accomplished:

- Now, you are not weighing things in a balance, you are solving a controversy. You have relatively few people who are

26 Ibid., Apr. 10, p. 2.

27 Ib1d., Apr. 10, p. 2. 
screeming relatively loud [sic] . Now, we are still willing to talk about some kind of an arrangement whereby we can give the designation of sports fish to the steelhead, because essentially as I told you, it's a fact--basically it is a sports fish. The use of it has essentially been handed to sportsmen. We are still willing to talk about some kind of a designation which will permit us to go ahead and have an orderly, well regulated, commercial fishery that's on the same stream. 28

The industry, by recognizing steelhead as a game fish, was willing to make a compromise with those sportsmen who "were not screaming too loud." In return, the industry would be protected and enabled to continue operation on the Columbia.

Bugas accomplished several things with his long circuitous reply. He deftly presented his industry's view and position in a subtly persuasive manner. This presentation portrayed the industry in the best possible light. The fishing industry representative had shown himself reasonable and willing to compromise and accept a designation of steelhead as a game fish. Through his reasonable approach, he could attract Representative Heard's support. Finally, all sportsmen who asked for a strong sports stance were by implication the ruthless, loud, violent minority. This loud sports minority would never be satisfied until commercial fishing were eradicated--not so with the commercial industry. "We would like to see it (sports fishing) continue to grow. However the militant sportsmen seem to be satisfied only with the destruction of the industry. $" 29$

Bugas explained how commercial fishing was very tightly regulated. He stated that giving up steelhead would be a "loser" for the industry,

$$
\begin{aligned}
& { }^{28} \text { Ibid., Apr. } 10, \text { p. } 5 . \\
& 29 \text { Ibid., Apr. 10, p. } 2 .
\end{aligned}
$$


as there are always sportsmen who will keep pushing unt1l the nets are banned from the Columbia. The commercial industry has a historic right to fish, and it was (and is) justified in this right. It was, as well, willing to solve conflicts by compromise, that is, designation of steelhead as a game fish, with protection for the industry. Consequently, It did not expect to be able to solve the conflict with the militant sportsmen, but hoped to reach a compromise with the less militant game fishermen.

After Bugas' reply to Heard's questions, the sponsor of HB 1302 and Ted Bugas exchanged comments. McCready referred to the slashing of Oregon sportsmens' tires by sportsmen in Washington State and other problems related to steelhead useage. In reference to the exchange, between Bugas and McCready, Chairman McKenzie remarked:

I gather from your testimony, and your intent, and it seems to me we are getting over on the emotional theory instead of practical theory--maybe emotional theory is practical...but I gather from your testimony that we are just going to keep fighting over the same old number of fish. $30^{\circ}$

The committee then discussed the amendments proposed by the Game Commission. Representative Pynn moved that the committee adopt the proposed amendments. The following discussion ensued:

Representative Dugdale: "Is this the only set of printed amendments that has come before the committee?"

Chairman McKenzie: Yes, and this is the only set of amendments that has been brought to a vote.' 31

$$
\begin{aligned}
& 30 \text { Ibid., Apr. } 10, \text { p. } 8 . \\
& 31_{\text {Ibid., Apr. } 10, \text { p. } 12 .}
\end{aligned}
$$


Representative Cole: Just a couple of comments. I have never been able to buy the argument that these are the only amendments that anybody has ever presented, so these are the ones that should be passed...personally [Sic] and this is why I prepared this form of resolution for you to consider--is that I have no idea in my own mind what the proper solution to this problem is. I haven't studied it to that extent. I don't think the rest of you have. I think, therefore, it is praperly an interim committee study. If an interim study is allowable, and it apparently is under the present law, what is going to be the difference now than [sI ] it would be under this bill, since it merely says we're turning the incidental [stc] over the State rather than selling.1t. The problem is still there, 1s it not? You are still supposedly taking fish away from the sports fishery through the incidental catch. All that is changing is that the fish are not getting paid for--State institutions are getting it, [sic] but it still is supposedly coming out of the run.

Representative Detering: I haven't followed all iterim studies, but I assume we've had iterim studies on this subject, haven't we, in the past? 32

The committee was aware of no previous studies and apparently there were none.

THE FIRST VOTE -- APRIL 10, 1969

After Detering's comments on interim studies, a roll call vote was taken on Representative Pynn's motion to adopt the Game Commission's proposed amendments. The motion failed; Representatives Cole, Heard, Peck, Turner and McKenzie voted "No!" 33

Why did the Game Commission's proposed amendments fail on April 10, 1969 Let us take a closer look at the committee members and their possible motivations: Committee Chairman McKenzie represented Coos and Curry Counties; encompassing both commercial and sports interests. He

$$
\begin{aligned}
& 32 \text { Ibid., Apr. } 10, \text { p. } 12 . \\
& { }^{33} \text { Ibid., Apr. } 10, \text { p. } 12 .
\end{aligned}
$$


apparently disliked courists and was not overly fond of sports fishermen intruding and blocking access to streams and littering the areas in which he was born and raised. McKenzie had friends on both sides--John McKean of the Game Commission and Theodore Bugas from the industry.

It would appear that Chairman McKenzie would not have supported the passage of legislation without balancing conflicting interst claims. The non-compromising stand of the sports interests precluded the possibility of obtaining McKenzie's vote.

Wayne Turner had both commercial fishermen and sports fishermen for constituents, but had strong labor backing and thus voted with the industry (management-labor).

Grace Peck voted in favor of commercial fishing interests. She has long been sympathetic to commercial fishing, and generally votes with labor--(the amalgamated Meat Cutters and Fish Butchers is allied with the industry).

George Cole was from Clatsop County, the home of Bumble Bee Packing Co. and commercial lobbyist Theodore Bugas. 34

Fred Heard was described as the "swing member" by almost everyone concerned, excepting Connie McCready, who referred to him as the "supposed swing member." 35 Heard professed neutrality--he stated he was seeking a compromise--Bugas apparently had the benefit of any doubt in Heard's mind, because of Bugas' response to Heard's "balanced scales" speech in which he stated the willingness of the industry to compromise.

34 Interview with McCready, Aug. 4, 1969. 35 Ibid. 
The "Yes" members of the committee, Representatives Connie McCready, Allan Pynne, Gerald Detering and Robert Dugdale, represented areas in which sports fishermen were strong.

\section{THE INTERIM COMMITTEE}

Following the defeat of the Game Commission amendments, George Cole stated that he considered the steelhead controversy to be very complicated and he felt it needed more study. He submitted a draft of a house Joint Resolution for an interim study of the conflict. He then moved that the committee act on the resolution. McCready responded to Cole's motion for an interim study by stating her opposition to a study--unless there was action on her bill.

A roll call vote was taken on Cole's motion. The motion passed, with Representatives Detering, Dugdale, McCready and Pynn voting "No".

Following the vote, a subcommittee was appointed to review Cole's proposed House Joint Resolution for an interim committee. The subcomittee consisted of Representative Cole, Pynn, McCready and Heard; Heard was designated chairman. 36 Heard's appointment was not surprising for a. number of reasons: (1) He professed neutrality; (2) he sald he was interested in a compromise; and (3) he supported the chairman. Item ( 3 ) was probably the major factor.

On Apr11 16, 1969, the House Subcommittee met again, with Heard presiding as chairman. Members of the subcommittee discussed the proposed House Joint Resolution for an interim study, 37 as well as a possible

\section{Fish and Game Committee Minutes, Apr. 10, 1969, Pp. 12-13.}

37Cole's Proposal recognized the problem of controversy over steelhead and proposed an interim committee to study it. Ibid., Apr. 10, 1969. 
compromise to HB 1302. McCready stated there had been previous studies on fish and game, of which the committee was unaware. The subcomittee decided to wait until the next meeting before taking any action on Cole's resolution--the delay would give the subconmittee time to obtain the earlier reports

After deciding to wait until the next subcomittee meeting before proceeding on Cole's resolution, the committee discussed a possible compromise to HB 1302 suggested by McCready. Her suggestion was quite similar to Senate Bill No. 406-- Senator Elfstrom's bill. The proposal submitted by McCready would allow an incidental catch of steelhead, but the catch would be minimized. After McCready submitted her proposal, the subconmittee members decided to adjourn so they could consider at the next subcommittee meeting the proposal suggested by McCready and the resolution moved by Cole. 38

The next day, April 17, 1969, the House Fish and Game Committee met in a work session. Surprisingly, no discussion was held concerning the subcommittee's consideration of Cole's resolution or of McCready's proposal. The House Fish and Game Committee members decided to by-pass these considerations as the subcommittee's work was incomplete on both the resolution for an interim study and McCready's proposal for amendments to $H B 1302$.

The House Fish and Game Committee began its work by responding to Representative McCready. She moved that the committee send HB 1302 to the floor with a do pass recommendation. A roll call vote was taken and the motion failed. With the exception of Crace Peck, who had been

${ }^{38}$ Ibid., Apr. 16, 1969, p. 1. 
excused, the same representatives voted "NO" who defeated the Game Commission amendments on April 10, 1969.39

McCready explained her reasons for moving passage of the bill. She stated that there were twelve interim studies from 1943 through 1965 and any additional interim studies - msuch as the one under consideration in the House Fish and Game Subcomittee -would not resolve the controversy. She also stated that she moved the passage of her bill, since no additlonal amendments had been suggested since the bill. wasn't going anywhere.40

In retrospect McCready's April 17 motion was a mistake. In addition to repeating the defeat of April 10, 1969, this move attempted to circumvent the procedures of the committee--McKenzie had assigned a subcomittee to study the proposed resolution for an interim study. Also, very importantly, McCready's moving of the original bill attempted to circumvent Heard's role of subcommittee chairman. If she had induced Heard to move more quickly in the subcomittee, or had allowed him time to frame a compromise, perhaps along the lines of her proposal for amendments similar to $S B 406$, she would have recognized both his importance as a subcommittee leader and his importance as the crucial broker between opposing factions in the subcommittee. If she had not moved passage of her bill on April 17, and if she had supported a stand permitting a reasonable incidental catch, Representative McCready could have put some pressure on Heard to compromise. It is likely that he would have compromised --perhaps even developing a recommendation for a compromise in the subcommittee he chaired. As it was, moving passage after no changes had

${ }^{39}$ Ibid., Apr. 17, 1969, p. 1.

40 Ibid. 
been proposed, with no commitment from the swing member, guaranteed an additional defeat. Also, this second abortive move hardened the opposition. Since the bill's supporting groups were generally loathe to compromise, the opposing faction with the marginal vote was under no obligation to be conciliatory in framing and dictating its "compromise".

On April 18, 1969 the House Subcomittee met again; the subcomittee reviewed former studies. Subcommittee members noted that no legislation had come out of these former studies; they redrafted the House Joint Resolution. According to McCready this draft was more objective concerning sport fishing than the first draft submitted by Cole on April 10, 1969. McCready described the subcommittee meetings as follows: "The subcomittee met repeatedly. Heard told me, 'either a suitable compromise would come, or he would change his vote in favor of the bill.' He kept delaying, stall, stall."41

On April 21, 1969 the subcommittee met and considered the cost of the interim study. The members decided that they were likely to experience difficulties in obtaining adequate funding for the study. Also, the Governor's assistant, Kessler Cannon, advised that he consfdered the proposed House Joint Resolution for an interim study to have little chance of passing. The subcommittee took no further action on the resolution for an interim study. 42

After concluding discussion on the proposed interim study, the subcomnittee resumed discussion of McCready's suggestion of April 16 to amend HB 1302 with provisions similar to those in Senator Elfstrom's

\footnotetext{
41 Interview with McCready, Aug. 4, 1969.

42Fish and Game Committee Minutes, Apr. 21, pp. 1-2.
} 
bill, SB 406, which would have allowed an incidental catch but would "minimize" the catch. The subcommittee discussed the words "minimize" . and "regulate". From this discussion, the focus moved to taking section ten of SB 406 and incorporating it into HB 1302 as a new section:

(3) The commission shall recognize steelhead trout as a game fish and shall use all reasonable means to minimize the incidental catch of steelhead trout by commercial fishing gear consistent with permitting a justiflable legal commercial fishery on food $f i s h$ present at the same time. 43

The subcomittee decided to have Legisiative Council draft amendments to $\mathrm{HB} 1302$ incorporating the above. 44

\section{THE SURPRISE MOVE}

On April 29, 1969, just before the House Fish and Game Committee met, McCready learned from a television newsman that there were proposed new amendments to $\mathrm{HB} 1302$, but not the amendments. based on SB 406 which were to be presented at the imminent committee meeting. Pynn also learned about the new amendments just before the House Fish and Game Committee met, by talking with Heard. Pynn shared membership on a committee with Heard, who told him that there would be new amendments which satisfled hfm (Heard). 45

At the meeting of the House Fish and Game Committee, Representative Heard moved that the committee adopt the proposed amendments to HB 1302 .

$$
\begin{aligned}
& 43 \text { Ibid., Apr. 17, p. } 2 . \\
& 44 \text { Ibid., Apr. 17, p. } 2 . \\
& 45 \text { Allen B. Pynn (former) Oregon State Representative, District 7, } \\
& \text { Clackamas. Interview held over the telephone, Portland, Oregon, Jul. 5, }
\end{aligned}
$$
1972. 
The amendment read as follows:

(3) Recognizing steelhead trout as game fish, and recognizing that they are intermingled in the Columbia River with other food and game fish, the commission shall use all reasonable means to regulate the incidental catch that may be taken under subsection (1) of this section by commercial fishing gear, consistent with continuing an optimum legal commercial fishery of food fish at. the same time, and shall protect the ultimate supply as provided in ORS 506.141 .46

Although. Representative Heard moved the new amendments, Representative Cole explained them to the committee. Subsection (6) of ORS 016 deleted steelhead from the commercial fishing laws, thereby recognizing it as a game fish. The Fish Commission had no jurisdiction over game fish except as indicated in ORS 509.030 which provided for an incidental catch. Subsection (3) of ORS 509.030 of the amendment is an addition, to further instruct the Fish Commission to use all reasonable means in regulating the incidental catch.

Representative McCready asked Representative Cole the reasons for deleting Sections 1 and 2 of the original bill. Representative Cole replied that Legislative Council was requested to draft amendments to HB 1302 which would name steelhead as a game fish and would provide for the continuance of an incidental catch under the direction of the Fish Commission. These were the amendments which Legislative Council drafted for Cole and it was Counc1l's opinion that Sections 1 and 2 of the original bill that proposed a change in the game code were unnecessary. McCready replled to Cole that when she asked Legislative Council to draft her bill early in the legislative session, Sections 1 and 2 were included. McCready then explained these two sections. HB 1302's sponsor 
also questioned the word "regulate" and the word "optimum" in the proposed amendments. McCready stated that this amendment did not indicate what means there would be to control the incidental catch. She also questioned the definition of ultimate supply, "for these reasons I would find these amendments unacceptable. I would propose that the committee refer HB 1302 to the voters. 47

McCready's motion to refer HB 1302 to the voters was illustrative of several things: (1) It displayed her frustration with the normal legislative channels; (2) it was an implied slap at committee proceedings, -committee actions did not represent the people; (3) it was a recognition of legislative defeat and of the inability to gain sufficient access to committee channels. These factors were all tied to McCready's bitter reaction to the power of the "negative lobby", i.e. the ability of a powerful organization with access to the legislative committee systems to block legislation inimical to its interests. 48 HB 1302 is a case example of the phenomenon of blocking legislation by an established group "inside" the established legislative system.

After she proposed a referendum, Chairman McKenzie reminded the committee that it was still discussing the proposed amendments suggested by Representative Heard. Representative Pynn, then asked that the Director of the Oregon Fish Commission, Robert Schoning, take the witness chair to clarify the problem. A long discussion followed. In essence, Schoning was of the opinion that the Fish Commission could administer the

47 Ibid., Apr. 29, p. 2.

48David B. Truman, The Governmental Process (New York: Alfred A. Knopf, 1960) pp. 353-355. 
statute. When questioned concerning the words "regulate" and "minimize" in reference to the incidental catch, he answered:

Speaking only for myself again, based on this hurried analysis, it would be easier for us to administrate [sic] in my judgment, than "regulate" or "reduce". "Regulate" means do something in measure of control, not necessarily up or down--regulate, then with no particular goal in mind as I interpret it. Reduce means reduce. But how far and from what? Minimize to me would indicate as low as you can be consistent with the other provisions of the text and consistent with our legal means to do so. I mentioned those earlier, so in that sense, I think "minimize" subject to checking with our attorney, would be clearer and would mean to me then, take as few as you can and still get an optimum catch of food fish. 49

Both Representatives Pynn and McCready stated that they felt the amendments should say "minimize" instead of "regulate".

Chairman McKenzie: From the information that we have and that has been made available to us, I think we're far from exterminating the steelhead--I think we're trying to solve an emotional problem. 50

Chairman McKenzie asked Ted Bugas to take the witness chair.

Representative Pynn: Mr. Bugas, maybe we could have your ideas on that particular little area we're talking about, the word "regulate".

Bugas: :The whole portion of subsection (3), Representative Pynn, must be read together to get the full understanding of what was attempted in this particular subsection. There is the phase of that subsection which reads "recognizing steelhead trout as game fish". This particular comment has never been said [sic] in our code before--this is the substance I think [sic] was attempted to be accomplished by this particular subsection. Recognizing that, and then back down into the middle of the paragraph, with reference back to subsection (1), which says Salmo gairdneri may be taken only as an incidental catch

${ }^{49}$ Fish and Game Committee Minutes, Apr. 29, op. cit., p. 5. 50 Ibid., Apr. 29, p. 5. 
with the lawful taking of other salmon, salmonoids or salmon species -- I think you can understand what was attempted under this... (word inaudible) at the moment from the pure language of the bill. I'm sure that everybody around this table realizes there have been many hours of negotiations, conciliation effort, everything [sic] would hardly describe what has gone into it.

The wording may not be perfect or satisfy everybody, I won't argue this.... If you recognize steelhead trout a game fish in the fish code, the code over which the Fish Commission has jurisdiction over [sic] the fish which is taken commercially, I think you have taken a huge step toward the solution of the problem. Having backed the... (word, inaudible) statement in subsection (3), then I think there's no choice under subsection (1) regulating it as an incidental take for the commercial fishing--that it must be cut down. I understand your disturbance as a practical [sic] of the law, Representative Pynn, about the particular word "regulate"; however, when you take it in view of the reference back to section 1, which pronounces salmo gairdneri as an incidental catch only [sic] of the commercial take of other salmon, I don't think it leaves as much doubt in the minds of the Commission as anybody on [sic] this table thinks. There's an attempt here to cut down the taking of steelhead. I think it will be done; it will be done by mesh restrictions, etc. This is really what was attempted in this particular section.

Representative Pynn: You're interested in cutting down the take of steelhead somewhat just a matter of... (word iriaudible), is that correct?

Mr. Bugas: That's a little inaccurate, incidentally, Representative Pynn -- we're not interested in cutting down really because it means the resource... (word inaudible). We recognize it as a sociological and political need.

There was further discussion on the word "regulate" and the incidental catch.

Mr. Bugas: ...up to date the agency that regulates us has not had the right to cut down on the size of that net because their only duty to cut it down [sic] was based upon the ultimate supply and the ultimate supply of that fish is not in jeopardy--in fact, it's excess to our needs...

Representative Pynn: If the word "minimize" was inserted in the place of "regulate" would it do violence to the concept of these amendments that [sic] they try to approach? 
Mr. Bugas: "I think "minimize" is acceptable of only one interpretation -- I think cut down to the least possible number, and in that sense I think it would be violent to what we have tried to do here."

Representative Pynn: Even though you have a clause in the end of the paragraph 3 pertaining to the optimum "legal"?

Mr. Bugas: "Yes sir."

The Oregon Wildife Federation Representative, Charles Henne, gave his support to the Heard amendments.

This is an honest effort to solve the problem and with possibly a few changes, it would go a long way to solve the problem. 51

Henry Rancourt, Legislative Chairman for the Oregon Wildlife Federation, said he would prefer "minimize" over "regulate". He further stated that he would prefer to have the Fish Commission zone the areas by regulation in order to keep the commercial fishermen out of particular runs of steelhead, and thus minimize the catch. 52

The Governor's Assistant, Kessler Cannon, indicated the Governor's position:

Mr. Cannon: I just want to let the record show that I was here in support of the amendment [sic], we haven't had an opportunity to look at them in their entirety, [sic], and also to let the record show that the Governor is in support of the amendment and that there will be a letter directed to the committee so stating his position. 53

Representative Pynn moved to amend Representative Heard's previous motion to change the word "regulate" to "minimize". A roll call vote was

51 Ibid., Apr. 29, pp. 6-8. .

52 Ibid., Apr. 29, p. 8.

53 Ibid., Apr. 29, p. 9. 
taken: the motion falled with Representatives Cole, Heard, Peck, Turner and McKenzie voting "NO". Representative Cole moved to send HB 1302 as amended to the floor with a do-pass recommendation. A roll call vote was taken, the motion carried five votes to four.

Representative Cole was delegated by Chairman McKenzie to lead the floor discussion on the measure, but the next morning McKenzie decided to lead the floor discussion himself.54 Debate on the House floor on May 6, 1969 was bitter. The opponents of HB 1302 said the bill was meaningless. However, McCready finally urged support of the bill in the hope that the Oregon Fish Commission would make it a true compromise. McCready cited a pledge by the Fish Commission to take steps to cut the commercial steelhead catch if the bill passed. McCready did, however, say she had considered asking to have her name removed from the bill as its sponsor "because my name already is on another abortion bill". 55 Earlier in the session she had signed State Senator Betty Robert's bill to legalize abortion. Representative Rod McKenzie said the issue was an emotional one between commercial and sports fishermen and that it had been blown out of proportion. He indicated that commercial catch of winter steelhead in the Columbia had averaged $8,400 \mathrm{fish}$ in the past few years. McKenzie declared that if the commercial fishermen were banned from fishing, the sportsmen could expect to catch 30 per cent of the $8,400 \mathrm{fish}$. Since it cost the State one dollar to propagate each $f$ ish, the argument was over a yearly amount of $\$ 2,500.00 .56$ (One-third of 8,400 fish multiplied by one dollar.)

${ }^{54}$ Interview with McCready. Aug. 4, 1969.

55"House Floor Debates," Tape Recording Number 18 R. G. L. 6 72 A-93 55th Session, 1969, Oregon State Archives, Salem, Oregon.

${ }^{56}$ Ibid. 
PASSAGE OF THE BILL

The bill passed the House on May 6, 1969. On May 8, it was read for the flrst time in the Oregon Senate. On May 9, it was read the second time. On May 12, a special hearing was held to allow interest groups to state their positions. Generally, the same groups which presented testimony in the House testified in the Senate. One new view of the bill was stated in the Senate hearing that was not stated in the House hearing. Theodore Bugas emphasized the time element in terms of amending the bill further. Bugas stated his position well.

The position of Bugas was that there was little time left to make alterations. Industry strategy was well timed for the few remaining days of the session. After some deliberation on amending the bill, the Senate Fish and Game Committee members agreed that there would not be enough time in the few remaining days of the session to amend the bill. If amended, the bill would have had to go back to the senate for concurrence.

By roll call vote, the motion carried to send the bill out with a do-pass recommendation. The only "NO" vote was cast by Senator John Inskeep of Clackamas County.

On May 15, Connie McCready made a motion from the House floor to recall the bill from the Senate. She persuaded a number of representatives opposed to the bill to vote with her to recall the bill to the House in order to "clean up the amendments". The recall motion lost 36 to 20.57

The bill proceeded to the Governor. McCall favored the bill and had no hesitation in signing it.

57 Ibid., May 12, p. 16. 
CHAPTER V

\section{WHY THE BIIL PASSED}

\section{LOBBYING RELATIONSHIPS}

To understand the legislative journey of House Bill 1302, it is necessary to examine the lobbying techniques and relationships of the active interests on both sides of the issue. Ted Bugas of the Columbia River Salmon Packers Association described his lobbying relationship with legislators as follows:

It takes influence, personal involvement. I take them to lunch, and I take them out on a gillnet boat. We form a longterm relationship. We are honest and forthright with the legislator. We give them good, reliable information. The lobbying relationship is no different than any other long-term business relationship.

Almost all contacts are informal. For instance, I saw Representative Pynn informally at a bar. Pynn tried to compromise, but his constituents wouldn't so he followed their desires. 1

From a legislative perspective, Representative Allen Pynn commented on the industry's lobby:

The commercial people--their information is more reliable, they are professionals and they only tell you things they can sustain. They give you both factual information and political information--who stands where. When you need more information on an issue --they will dig it up for you. It is reliable, and you have a natural tendency to give them the benefit of the doubt--in those grey areas. They

ITheodore Bugas, Executive Secretary of the Columbia River Salmon and Tuna Packers Association, interview held at the University Club, Portland, Oregon, Sept. 10, 1969. 
will assist you in keeping your record. They will buy you dinner; it happens a lot.2

Bugas spent most of his time with those legislators open to influence. Pynn noted that Bugas used the "soft sell" - " "we represent a lot of people." Bugas would then mention the numbers. Pymn further commen ted:

The single thing that helped the commercial people was their extremely good persuasive talent. Day in and day out, woek in and week out. This talent is soft-spoken, knowledgeable, soft sell. Ted Eugas works on it fourteen hours per day. He works with the legislators. Most legislators have no facts and figures-sports people are not as credible. They don't have the facts. Or, they overstate the facts. When you couple this with the fact that new legislators are busy, you can see the effectiveness of this reliable persuasive lobby. ${ }^{3}$

Representative Dugdale indicated that he met with Bugas ten times during the session. Five meetings were social and five were business. Dugdale asked Bugas to compromise with the supporters of HB 1302. Bugas told Dugdale that the industry could not compromise with sportsmen as sport fishermen would not compromise with the industry. Consequently, some two weeks before the vote, Representative Dugdale announced his stand to Bugas. "In all frankness I cannot vote with you."4 Dugdale

2 Allen B. Pynn, (former) Oregon State Representative, District 7Clackamas, interview held over the telephone; Portland, Oregon, Jul. 5, 1972.

IIbid.

4Robert E. Dugdale, (former) Oregon State Representative, District 6, Multnomah (West). Interview held at his home, Portland, Oregon, Jul. 8, 1972 . 
represented Nultnomah County with substantial sports fishing and tourist interests. Bugas' reaction was "that's ok, we are still friends. I - don't need to compromise; I have the votes." Dugdale stated, "Ted is the smoothest of the bunch, a good lobbyist-he never gets mad; top quality."

Dugdale remarked that Oreg on lobbyists are incredibly "clean and simple" in their approach and "experienced". "Lobbyists", he sald, "give information, reliable but colored with their viewpoint. Ted Bugas is one of the best in a group of professionals. He gave information, both of the nose-counting variety, and facts and figures as well."15

The effectiveness of the commercial lobby was obvious. Through supplying information of a political and technical nature to a legislator, a long term relationship was built. This relationship developed largely through the use of subtle persuasion. The legislator could be swayed over a period of time through personal interaction. The legislator often grew to know, understand, and appreciate the lobbyist. The interest group representative largely provided reliable aid to timepressed legislators. Also, the lawmaker could become personally fond of the lobbyist as they developed rapport. Through interpersonal interaction between legislator and lobbyist came a higher probability of the legislator assimilating some or all of the lobbyist's viewpoint. The lobbyist can be helpful to the legislator, such as handling minor clerical duties, picking up a luncheon or dinner tab, and thus heighten his opportunities to interact with and influence the legislator. The amount 5 Ibid. 
of interaction and the amount of influence depends on the lawmaker, the Iobbyist, and the interpersonal situation. What occurs is an intangible, subtle, often imperceptible change of the public representative's attitude. The process is continuous and major effectiveness lies in its subtlety. Through growing to know the lobbyist, the legislator can begin to view him more and more as a person and less and less as a representative of an interest group. Through Iunch and other social situations one gains a feeling for the other's sense of humor, his family, and his basic worth as a human being. As the relationship develops it is easy to become friends and rely on the lobbyist for more help and information. This trend is especially true when the opposing interest group (s) are without a lobbyist. This is precisely the unfortunate situation sportsmen and conservationists had to deal with in 1969. They had a conspicuous lack of competent, reliable, Iong term, persuasive lobbying talent--talent which provides information, assistance, and subtle, effective influence.

Bugas said "The lobbying relationship is no different than any other Iong-term business or social relationship." His remarks emphasized the difference between the industry and the sportsmen -- when we compare the remarks of Kenneth Gates, (past president) of the Association of Pacific Northwest Steelheaders, with those of Bugas, this difference becomes clear:

The sportsmen are weak, they work together, sometimes we work with key people. We are not strong over the state. We plead our cause. We wait until the session is ready, then we introduce legislation. The sportsmen need to organize ahead of time, from two to four to six years ahead of time. We have not done it as yet. We call on representatives 
from home districts and use wires. We send a few delegates of pickets down to the session. We have no money, no organization, no pressure. We are just seeking friends.

In addition to the Pacific Northwest Association of Steelheaders, the Oregon Wildiffe Federation and the Izaak Walton League had meager lobbying representation. Prior to the 1969 legislative session the Federation and the Walton League jointly supported a lobbyist. However, the Izaak Walton League decided to discontinue the arrangement during the 1969 legislative session. The Federation continued to support the Iobbyist--but without the Walton League's financial support. The Federation did not provide a salary; it reimbursed the lobbyist's expenses, approximately fifteen hundred dollars in 1969. The lobbyist was Charles Henne, as indicated in Chapter II. Henne ran the advertisement in the Portland Oregonian 1942 - WILI YOUR VOTE MAKE HIROHITO HAPPY?7

Henne's former extensive ties with commercial fishing hurt his effectiveness with sportsmen. Some trusted his dedication to wildlife, some did not. Henry Rancourt, Legislative Chairman of the Wildlife Federation in 1969, thought Henne worked with the packers. "I never knew what Henne was thinking. The Izaak Walt on League never trusted him. "8 Bob Holloway, Chief of the State Game Commission's Information and Education Section, stated that, "Charlie was almost deaf. His cap-

6Kenneth Gates, (former) President, Pacific Northwest Association of Steelheaders, Portland Chapter, interview held at his hame, Portland, Oregon, Aug. 5, 1969.

${ }^{7}$ Oregonian, 2 Nov. 1942, section 1, p. 5. cols. 5-8.

8Henry R. (Ranny) Rancourt, President Multnomah Hunters and Anglers, interview at his office - Lloyd center, Portland, Oregon, Aug. 8, 1972. 
abilities were limited. His physical condition was poor. He became awfully bitter; he became angry because poople would not compromise." 9 Phillip Schneider, former Director of the Commission, described Henne's function as one of monitoring legislation: "watching it, doing a little testifying, he rode hard from day to day. He was essentially an observer. 10

HB 1302's most effective lobbying opponent, Ted Bugas, described Henne as "a former commercial fisherman who had previously represented the gillnet fishermen." He commented that "recently Henne had gone over to wildlife and was trying to find a compromise. Henne was "an old guy, an honest individual." 11

on the other hand, Connie McCready labeled Henne a "double agent, before, during, and after HB 1302 's passage."I2 McCready's opinion of Henne was not surprising. Henne supposedly backed HB 1302, yet he was open to compromise. Apparently, if he dealt with the commercial fishing interests, he could not be honest. (Since both Henne and Heard were in the middle, it is not surprising thet the bill's spons or was distrustful of them. They were supposedly behind her, yet when it came down to a.

9Robert Halloway, Chief Information and Education, Oregon State Game Commission, interview held at his office, Portland, Oregon, Aug.2,1973.

10Phillip Schneider, (past) Director Oregon State Gamo Commission, interview held at the Shearton Hotel, Portland, Oregon, Jul. 17, 1972.

IIInterview with Bugas, Sept. 10, 1969.

12Connie McCready, Commissioner of Public Utilities, City Hall, Portland, Oregon, to Emery Alberts on, June 5, 1972 
fight, they both backed a compromise which appeared to support the commercial stand. Therefore, Henne and Heard were untrustworthy in McCready's view).

Finally, Henne was described by a psst President of the Izaak Walton League, as a mediator who fought unselfishly for the resource itself. Interestingly, Henne willed his estate to the Izaak Walton League.13

Charles Henne supported amendments authored by the commercial industry and introduced by Representative Heard on April 29, 1969. As a result, he lost support within the Oregon Wildiife Federation. He was viewed with increasing suspicion as well by some in the Izaak Walton League and by most of the members of the Pacific Northwest Association of Steelheaders. 14

Henne's age, hearing disability, and the distrust of him by many in the sportsmen's groups severely hampered his effectiveness. His support of the Heard amendments precipitated a heated conflict within the Wildlife Federation. Henry Rancourt, head of the Multnomah Hunters and Anglers (about 300 in number) and legislative chairman of the Federation left the Federation over the situation. When Rancourt broke with the organization, he led his followers out. They supported the Pacific Northwest Association of Steelheaders and the Izaak Walton League in opposition to HB 1302 as amended. Rencourt's refusal to support HB 1302

13Charles Collins, (past) President Izaak Walton League, Oregon Division, interview held at the Sheart on Hotel, Lloyd Center, Portland, Oregon, Jul. 17, 1972.

14Robert Buker, (past) President Pacific Northwest Association of Steelheaders, interview held at Bass and Panfish Club Meeting, Auditorium, Lloyd Center, Portland, Oregon, Jul. 5, 1972. 
as amended split the Federation and further strengthened existing antagonisms between the organization and other groups.

As indicated above, sportsmen and conservationist groups were not sufficiently organized to lobby effectively. They did not have the funds to hire a full-time lobbyist. They were volunteers and amateurs. As a result, they did not have a single spokesman to speak for them as the industry did. Commercial fishing had Ted Bugas to speak for a number of organizations, and he was able to lead them into supporting the Heard amendments. He was persuasive enough to build a strong coalition behind his efforts.

It is of value at this point to indicate the factors which determine the influence of groups. There are at least seven such factors: (I) size; (2) prestige; (3) membership cohesion; (4) leadership skills; (5) membership distribution; (6) ability to rally wide popular support and the assistance of other groups; and (7) resources, especially financial. 15

The commercial fishing lobby clearly had advantages over the sport fishing interests in at least five out of these seven factors. Membership distribution (number 1) and numerical size (number 5) were the only advantages the sport-conservation organizations could claim. The industry had clearly superior lobbying forces.

\section{LOBBYING THE "SWING" MEMBER}

The effective industry Iobbyist, Ted Bugas, concentrated his attention on the crucial swing vote, Representative Fred Heard of

15George S. Blair, American Legislatures: (Structure and Influence, New York: Harper and Row Publishers, 1967) p. 305. 
Klamath Falls. ${ }^{16}$ The game fish proponents also attempted to influence Heard, who had indicated in his "balanced scales speech" on April 29, 1969, that he was interested in a compromise. None of the fish lobbying interests talked compromise or indicated a willingness to be flexible except Bugas. In retrospect, the fact that Heard finally sided with a compromise designed by Bugas is not very surprising. Heard had been at least neutral or possibly even slightly pro-industry since he voted against the Oregon State Game Commission's proposed amendments which were defeated on April 10, 1969 in the House Fish and Game Committee. Cn April 17, 1969 the Klamath Falls Herald and News carried a legislative report of Representative Heard. Heard stated:

This week was a significant one in the legislature. I was under a great deal of pressure in the Fish and Game Committee because mine was the "swing vote" on the bill to make steelhead a game fish in oregon. There were four votes for HB 1302 and four votes against it... [sic]

This bill would deny the commercial fishermen this catch on the Columbia. I stayed up until 3:00 A. M. the night before we were to vote on this bill and re-read all of the testimony pertaining to the bill... I considered the loss of jobs and the importance of the fishing industry to Oregon. I also took into account the interests of the sportsmen.

This bill, it seems to me, would not offer a permanent solution to this age-old debate between the sportsmen and the industry. It is hypocritical to talk, on the one hand, of encouraging industrial growth in Oregon and on the other, to kill one of our oldest industries. Another factor is the fact that tourism is growing in Oregon and sports fishing is an important part of its future.

Summing up then, there were so many unanswered questions on both sides. People who were committed, one way or another, wanted [sic] to vote their way. As an interested by-

'16Heard was from "safe ground" in Klamath Falls. Although his constituency included sport fishermen, they have generally been unconcerned with events on the Columbia River. 
stander, I could not really vote for either side. I will be prepared to support the interim committee report. They will hold hearings, discuss the issues with both sides, and then come to a fair decision based on what is best for the state as a whole. 17

Until the midale of April, Heard was professedly neutral. He indicated that he wanted fair treatment for both groups. He also noted that he was unwilling to do anything that would damage either jobs or the fishing industry. As he came to a vote, Heerd was against a strong sports stand. He voted against the Game Commission amendments and he voted to form an interin committee. By mid-session he was voting with commercial fishing while verbally holding out for a compromise.

However, according to Bugas, Heard could not be influenced beyond a certain point; his motivation was "honorable and decent." Commercial fishermen were suspicious of him, feeling "you're not 100 per cent with us, you are 100 per cent against us."118

As the committee deliberations continued, Heard told Bugas "I frankly lean your way, also in my opinion, Connie believes that I will go with her." Bugas stated that "Fred Heard did more to make steelhead a game fish than Connie McCready. 19 Heard wanted to force something out of the 1969 Legislative Session. He came up with amendments and he

17Representative Fred Heard, "Legislative Report: Student Observers are Fun", Herald and News, 17 Apr. 1969, p. 12. Cols. 1-3.

18Interview with Bugas Sept. 10, 1969.

19 Ibid. 
earnestly felt. something should come out of the committee."20

Although Heard leaned toward Bugas' camp he wanted some kind of compromise. Bugas steadily attempted to influence Heard and kept him supplied with information. However, Bugas indicated that "at one point I tried to give Heard too much information." 21

By April 17, 1969, the date the Klamath Falls Herald and News carried Heard's legislative report, Heard was clearly indicating his concern for jobs and the possibility of drydocking the industry. He was not on one side or the other--but was seeking a compromise, and because of this, he remained somewhat vague until the final vote. Bugas said "I had a gradual feeling as time went along-how does it work? At the day of the vote, the moment of the vote, he made up his mind."122 Heard remained vague until the last minute, but Bugas felt he had him. By April 29, Representative Heard was within the commercial camp, to the point of fully supporting the industry's compromise and voting against game fish proponents' attempts to change the commercially authored amendments.

Ted Bugas was able to persuade Heard to introduce the commercially authored amendments. It is likely that Bugas' soft sell persuasiveness aided his efforts with Heard. In addition, the commercial lobbyisis. understood where Heard was at each point in the lobbying process. He was one of the few who did not misread Heard.

20 Ibid.

2 I Ibid.

22I Ibid. 
Bugas was shrewd, and found where Heard was, and was flexible enough to support recognition of steelhead as a game fish. By doing this he attracted, then held Heard's support. In return, Heard obtained increased power and status. He was appointed subcommittee chairman; he was wined and dined by both sides; he introduced the amendments and appeared to be leader of the compromise, and he cast the crucial deciding vote.

A comparatively large number of people were surprised at Heard's stand. Ted Bugas was one who was relieved, not surprised. The commercial lobbyist did mention that "Heard never made a comitment before he voted." The bill's sponsor largely misread Fred Heard's ambiguous stance as did several other politicians. According to McCready, Heard's activities were "stall, stall".23 Stalling in committee occurred from February to May (with one month of the deliberations in the subcommittee coneerning a possible interim study of steelhead -- with Heard as chairman). When no suitable amendments were forthcoming, Representative Heard kept saying a suitable amendment would come or he would support the original bill. Heard kept saying-- if no compromise is found, be would change his votew- he kept delaying.

In contrast to Bugas' perception of Heard's motivation as decent and hon orable, uncommitted until the final vote, Connie McCready described him as delaying, promising to change his vote if necessary. McCready described Heard as "practicing moral dishonesty. He deliber-

23 Interview with McCready, Aug. 4, 1969. 
ately misled me. 124

Heard said to Bugas, "I frankly lean your way. Also, in my opinion, Connie believes I will go with her. ${ }^{25}$ (At this point Representative Heard did not go to the bill's sponsor and tell her he frankly leaned towards Ted Bugas.) Heard's consistent verbal position as a broker between interest groups necessitated ambiguity in his relations with the sponsor of the bill and apparently some candor with Bugas. However, Heard was not totally ambiguous since he had indicated his vote would go with those who offered the best compromise in his "balanced scales speech" on April 10, 1969. Game fish supporters either failed to understand Heard's cue or more likely were loathe to act on it, ie., to compromise.

Others misread Heard as well. Kessler Cannon. "We simply mis-. read him - assumed because he was out of a fish-game county he would support sports groups. Heard wanted to play the statesman's role. We read him wrong; he was in Bugas' camp as early as the middle of the session. "26

"Connie thought she had a commitment early in the session from Heard. She felt early in the game that he was committed. She thought she had him." However, Pynn talked with him in mid-session. "Heard

\section{Ibid.}

25 Interview with Bugas, Sept. 10, 1969.

26 Kessler Cannon, (former) Administrative Assistant Department of Natural Resources, to the Governor. Two interviews held at the State Capitol, Salem, Oregon - Oct. 14, 1969, and JuI. 26, 1972. 
Was uncomitted, however, we thought he would go with us."127

Representative Dugdale. Dugdale had spoken with Heard early in the session. Heard indicated he had thoughts similar to Dugdale's -Heard hadn't definitely made up his mind then, but he thought he would support sport fishing. Dugdale remarked: "I took my hat of to Bugas, he got to Heard. Can't condemn him [Bugas] for doing a good job."28 Bugas was very effective because Connie McCready thought she had Fred Heard; she was working hard on him. However, by mid-session the situation was unclear. Dugdale remarked, "No one knew until the vote for sure which way Heard would go."29 Dugdale remarked he had told Ted Bugas a good two weeks before the vote that he could not support him, "that it was a matter of good ethics to clear yourself ahead of the vote on a hot issue such as this." Dugdale was of the impression Heard was playing both sides for all he could get. Heard was not a safe vote: It was a "poker situation." 30

Dugdale's perceptions agreed with Bugas ' - Bugas stated Heard did not take a. stand until the final vote. Dugdale's understanding of Heard's position was relatively clear. Heard was vague, yet he seemed to indicate he was on their side when he talked to individuals from either side.

27Interview with Pynn, Jul. 5, 1972.

28 Interview with Dugdale, JuI. 8, 1972.

29 Ibid.

30 Ibja. 
Wendell Haley. Haley of the Izaak Walton League also shared the misconception of Heard's stand held by many game fish supporters. Haley spent an afternoan with Heard early in the 1969 session. Speaking in 1972, Haley said "I never got \& better snow job." Heard was vague but Haley understood Heard to say that he would support the sport fishing side of the conflict. 31 Heard's vague agreoableness led most people to believe he probably supported them.

Why was Bugas successful in understanding and persuading Representative Heard? Bugas had long-term experience as a lobbyist. He was constantly at the Legislature when it was in session. Bugas had time to spend with legislators and with other lobbyists. He concentrated his efforts on the one issue. This was not true of the opposing interests. The sponsor of $\mathrm{HB} 1302$ was functioning as legislator and lobbyist as well as, leader of the sport fishing interests. She spent time with Heard; however she as other legislators had lawmaking responsibilities. on the other hand, Bugas concentrated solely on Heard. In addition, McCrciady was not as realistic as Bugas was about Heard. Moreover, McCready was less able to influence Heard because Bugas was willing and did compromise.

In the realm: of experience and accumulatedi. polished skill in handling legislators, Bugas had the advantage. Bugas also had the time to use information and personal interaction to move Heard in the direction of support for the industry. He had the skill and the political wisdom to alter the commercial stand; he moved towards that grey area

3I Wendell Haley, (former) President, Izaak Walton League, Oreg on Division, Interview held at his home, Portland, Oregon, Jul. 10, 1972. 
of compromise that would attract necessary support.

In addition, the commercial lobbyist had either created a more flexible constituency which could be persuaded to go along with the realities of political compromise or he was able to weld a tighter coalition behind him. He spoke for several organizations, including the uneasy alliance of labor and management. 32

Bugas had a better image to present to undecided legislators, such as Fred Heard. Bugas was respected for his professionalism. 33 He also had a conciliatory image. He was not out to destroy sport fishing. However, sports fishermen were out to drive his industry from the river. Also Bugas was willing to compromise. He stated his willingness to compromise many times. (This use of a favorable image was highly effective. McCready felt its power. She referred to what she termed the use of the smear to discredit a strong sport fishing stand. Bugas of ten said "Not one of the wild ones, the reasonable people in both camps"). 34

Besides the favorable image he projected, Bugas had another weapon, the soft sell approach, which he used effectively. This was one of his most important weapons, and the most subtle.

Moreover, Bugas had access to Committee Chairman Rod McKenzie, and that access could be used to sway legislators. As McCready noted,

32 Interview with Bugas, Sept. 10, 1969.

${ }^{33}$ Interview with Pynn, Jul. 5, 1972.

34 Interview with McCready, Aug. 4, 1969. 
Bugas and McKenzie were "old friends".35 The appointment of Representative Heard to the subcomittee chairmanship was a reward for playing the game, particularly ego enhancing for a freshman legislator. For Heard to successfully introduce surprise amendments in the eleventh hour was also quite an accomplishment for a novice legislator. Heard's "playing it down the middle" for a lengthy period of time caused both sides to offer many kinds of tangible and intangible rowards to sway him. The major rewards were increased power and a subcommittee chairmanship. These reward supported the status quo within the Legislature. The established quilibrium within the Legislature can be ideal for an entrenched group to use to defend its status. 36 The comercial industry was established and it used its lobby effectively to influence the passage of $\mathrm{HB} 1302$, initially the product of sport fishing interests. Nevertheless, with all the lobbying assets' the industry possessed, the closeness of the 5-4 vote was surprising. No doubt, the constant increase in the number of anglers and the insistent demands by them on the Iegislature made legislators increasingly awere of these constituents. The unorganized sportsmen were becoming less anonymous and more cohesive. They were beginning to organize somewhat more professionally. Their growing professionalism was not enough, however, to woo Representative Heard from his "middle of the road stance". He was from safe ground -- Klamath Falls -- and he was removed from the pressures of Columbia river steelhead fights. He was more open to consider

\section{Ibid.}

36David B. Truman, The Governmental Process (New York: Alfred A. Knopf, 1960) pp. 353-355. 
the issue without bias, and therefore more open to persuasive talent, Theodore Bugas, and not the less organized, less experienced sportsmen or Representative Connie McCready.

\section{POLITICAL STYIES}

Finally, a factor not previously discussed enhanced the lobbying direated at Representative Heard and the passage of the bill. This factor is the nature of politicians themselves, their stance or style. Some prize taking a stand and not compromising, while others pride themselves on reasonableness, conciliation, bargaining and the art of compromise. Bugas and Heard both spoke the language of the latter. McCready was less open to compromise, and her strongest beckers The Izaak Walton League and the Pacific Northwest Association of Steelheaders shared her attitude. Because of this, misunderstandings occurred between McCready and Heard.

Bugas, in contrast, had rapport with Heard and was very successful in planting the idea that "you don't have to choose between sport fishing and commercial fishing". Bugas pointed out that the conmercial industry was not out to ruin sport fishing: "We hope it continues to grow. On the other hand, they are out to get us". The industry presented the image of reasonableness and decency. The strongest sports argument as paraphrased below never got through:

Sport fishing is a rapidly growing industry. The steelhead are worth much more as a game fish per pound than as a canning fish. There is a choice between the two industries. The average sportsmen must fish for two days to obtain a stee ihead. ihen the gillnets go in, the sport catch is negligible. Fish are dispersed and nets teke large "trophy 
rloh". Consoguontiy suortamon pack zosand Jonvo whon tho note arrive on the river. Commerciel fishing damages sport fishing.

The stand of Representative McCready and her supporters was hurt by an unwillingness to compromise. Heard was a walking compromise. McCready did not play his game or appear to be part of his political style. Finally, there was less in it for him if he supported her. She did not designate committee or subcommittee chairmanships. She did not offer him a chance to enhance his rediation skills with a compromise. She and the sportsmen did not have the budget to extensively wine and dine him. In short, within and outside the committes structure, she and her supporters had less to offer than Ted Bugas and the industry-sympathetic committee chairman.

\section{EXECUTIVE INFLUENCE}

As: indicated throughout this paper, influence from the Governor's office came mainly in the person of Kessler Cannon. According to Cannon, the most effective infleunce was informal-on the telephone, in the hall, at dinner. Whatever the situation, the informal meeting was the most effective way to work with legislators. The most productive technique was to taik to the uncommitted legislators--Representatives Detering, Dugdale, and Heard. Cannon was a source of information-- as to the positions taken and appeared likely to be taken by legislators and others.

\section{ACCESS TO THE CONOTTWEE CHATRMAN}

What was the role of Chairman McKenzie in terms of access? Connie McCready's bill was introduced on February 11, 1969. One month Iater, 
on March 11, the committee had its first work session. The State Game Commission's proposed amendments were defeated on April 10, 1969, and the bill did not move until April 29. Her frequent appeals to move the bill as she introduced it were Ignorod. Clcarly, Representatives McCready had limited access to the committee chairman as the bill did not leave the committee until April 29. When it moved, it moved against the votes of McCready and her supporters.

Representative Pynn observed: "The committee chairman did not call the bill" and in its original version Pynn felt McCready was not aggressive enough. Pynn encouraged her to move. He felt it was her responsibility to move the bill. "Connie was lulled, she thought she had the votes necessary, she was being very patient and courteous to the chairman. It was virtually a tie situation; if she had acted earlier, she might have moved the bill". 37

Pynn said he did most of the pushing to get it out of committee. Pynn observed that McKenzie was procedurally fair. However, Pynn said he felt McKenzie privately favored commercial fishing. "McKenzie was always on one side in terms of his personal preferences, I'm sure, but he plajed a fair game; he is honest." McKenzie did not say which way the committee should vote. In spite of his formal fairness, "Bugas had a great deal of influence with McKenzie and the majority of comittee members". 38

Pynn stated that if McCready had acted more aggressively, she

37Interview with Pynn, Jul. 5, 1972. ${ }^{38}$ Ibid. 
might have moved the bill. However, the real key to the bill was not aggressiveness, but compromise. If McCready had been able to sell her supporters an compromise, she might have produced a compromise the swing member could have supported. If she had enabled Heard to present the compromise (thereby allowing him to obtain the credit. and involving his ego in the compromise as Bugas did), then the comriittee chairman would probably have had a consensus of the majority of committee members. McKenzie would have been more open to pass a compromise which gave some recognition to the status of game fish but which did not harm the incidental catch rights of commercial fishermen.

Since legislative committee chairmen generally operate on compromise, and consensus, 39 McKenzie would have been more likely to support a compromise if it had a majority of the committee's support. Again, the key was Heard, the swing member, who although new to the Legislature, had the political'style of more polished veterens: conciliation, compromise, and ambiguity of stance.

As it was, the bill was amended very late in the session. Representative Pynn advised McCready to amend the bill, and his urgings, plus a very real possibility of no bill at all, brought the sportsconservation willingness to compromise - too little and too late. By engaging in "might have beens", we can see how the bill could have moved. If the sport fish backers had compromised sooner, and worked more vigorously for action from MeKenzie, they might have obtained a bill. If they had had a compotent, full-time lobbyist, he instead of Bugas might

39 Truman, Governmental Process, pp. 386-389. 
have persuaded Heard.

Finally, there was clear access of Governor McCall's staff to the committee chairman. Kessler Cannon noted that the most productive effort in terms of the bill was the successful encouraging of Chairman McKenzie to keep the committee members working for a compromise, when time was short and all hope of compromise lost. 40

\section{STRATEGY AND TACTICS OF THE MAJOR INTERESTS}

What were the various strategies pursued by the different interest groups?

The commercial lobby had one objective, as described by Bugas: "We blocked the unacceptable bill, and we would push out the bill only if necessary - after we killed the obnoxious one. We would replace the obnoxious one with a compromise dictated by us."147,

The commercial industry's strategy tumed entirely on blocking: bar the passage of the bill and break the barrier to the bill's movement only if necessary and only if the "obnoxious" original bill were destroyed. Representative Heard's swing vote held the bill in committee. Bugas' access to the Committee Chairman helped to hold the bill in committee. The appointment of Heard as House Subcomittee Chairman also helped delay the passage.

Bugas stated:

Representative Cole and myself, with the aid of legislative

40Interviews with Cannon, Oct. 14, 1969 and Jul: 26, 1972. 4IInterview with Bugas, Sept. 10, 1969. 
counsel, wrote the amendments. We defeated Connie's bill and put our own out. We put the compromise together and dictated the final product. We gave up something not because of preservation reasons-the resource is in fine shape-we gave up something because of political necessity. We dictated our own compromise. Our side won the battle not to let it out of committee until we wanted it out. Rod McKenzie, Representatives Cole, Peck, Tumer and Heard stuck by us. 42

The success of the commercial lobby lay in its ability to compromise, which was indeed necessary in order to gain Representative Heard's support and to block a possible injtiative on the part of the sportsmen. The compromise also drew the support of Governor McCall. After the Heard amendments were presented to the Governor, he backed them and removed executive pressure on the industry for designation of steelhead as a game fish.

of no small significance was the ability of the commercial industry to time its "dictated compromise" and keep it a secret until April 29, 1969-- the day Heard's proposed amendments were unexpectedly introduced and approved in the House Fish and Game Committee. A week before the Heard amendments were proposed, a different set of amendments based an Senate Bill No. 406 were drafted by Legislative Council for Connie McCready. She believed that the sport fish supporters could live with these amendments. However, at this point, the full committee meeting was cancelled.

McCready's amendments were apparently unacceptable to Representative Cole and Bugas was out of state. McCready asked Heard to support 42 Ibid. 
them. He stalled, so McCready threatened him with an initiative (the standard threat of groups-and their legislative supporters with little legislative access). On the day of the vote, a television newsman came to McCready and asked her if she was ready to vote for the pending amendments. McCready did not even know about the new amendments. The newsman said Heard was going to move adoption of some amendments and Bugas was there to talk for these amendments.

She contacted Charles Henne and he said "I can't show them to you yet--trust me, trust me". McCready said Henne's replies to her were only to "stall--stall". 43 Then Cole, Heard, Bugas and Henne held an informal conference. They reviewed the amendments the game fish supporters had drafted based on SB 406 . The amendments that Bugas and Heard had were similar to the game fish supporters, relative to the incidental catch except for the word 'minimize' in the game fish amendments. 'Minimize' was deleted for the word 'regulate' and then Henne, Bugas, and Heard had a consensus. Shortly thereafter, the House Fish and Game Committee met. The amendments were then in McCready's words, "railroaded". McCready remarked, "Heard couldn't even carry his own amendments." He was too unfamiliar with them. Heard gave them to Cole instead. 144

With the Governor behind the bill, commercial interests lobbying for passage, the conservation-sports coalition split, and the Wildlife Federation behind the compromise, the bill moved through committee. Shortly thereafter, with the commercial amendments intact, it moved

43 Interview with McCready, Aug. 4, 1969.

44 Ibid. 
through the House of Representatives.

The industry. Iobby had enough political influence in the committee to block the bill as introduced. It also possessed enough political wisdom to know that another initiative was a real possibility. More importantly, the necessity of a compromise to attract Heard's support was evident to the industry. It presented its "dictated compromise" as a surprise move. This unexpected tactic enabled the industry to frame its own amendments and move the bill rapidly through committee.

The strategy of the Izaak Walton League and the Pacific Northwest Association of Steelheaders was a "pure" one: no compromise and a fight, a never-ending striving to push for game fish status. When these organizations were defeated in the past, they continued to come back fighting. It was this ability to keep struggling that brought what measure of success they obtained. Their power to mount successive initiatives and to keep the publicity waters stirring was of some longterm importance.

When organizations such as the sport fishing proponents had little power, their only choice seemed to be to inflame the issue and refuse to negotiate their position. The fact that sport fishing is growing rapidly has been stated. It is no surprise that a growing number of sportsmen and conservation-oriented game fishermen find their way into sports groups and other allied organizations. This group was fmustrated and they were nearly powerless and would not negotiate. There is a logic to this stance. If you have little or nothing, nego tiation may get you what you already have--nothing. Generally speaking, intransigence, a great deal of commotion and publicity, coupled 
with a growing number of followers and a goal relentlessly pursued can bring some results; perhaps only limited incremental results, but results nevertheless. However, there is a price for refusing to negotiate, just as there is a price for compromising. The refusal to compromise can mean that compromises can be made: for, against, or around you. The commercial packing industry offered the Governor a bargain at the eleventh hour. Governor McCall accepted the compromise as did the Oregon Wildilife rediration. However, the Federation's stand split the sports-conservation coalition and the Federation itself splintered. Its chief executive officer and part of the organization backed the compromise. Henry Rancourt, the Federation's legislative chairman, and some 300 Multnomah Hunters and Anglers, left the Federation. 45

The bill's adherents did indirectly produce a compromise by their rigid stand. The sports groups were caught off guard and were unprepared for the compromise drafted at the request of the industry lobby and presented by Representative Heard.

The strategy of the executive lobby was to stress to each side in informal meetings the futility of an initiative. The Governor's assistant kept repeating to each side "The initiative is a humiliating failure to the sportsmen. They Iose time and effort. On the other hand, the initiative is a costly success for the industry, as well, [sic]. the threat of a win by the sports groups is in the background". 46 To accomplish the executive strategy, the Governor's representative met

45Henry R. (Ranny) Rancourt, President Multnomah Hunters and Anglers, interview held at his office - lloyd Center, Portland, Oregon, Aug. 8, 1972. 46Interviews with Cannon, Oct. 14, 1969 and Jul: 26, 1972. 
repeatedly with industry, committee members, and sport conservation interests. The Governor and Kessler Camnon met formally and socially with John McGowen, the head of Bumble Bee Sea Foods. Tom McCall attempted to persuade the industry leader to accept a compromise but McGowen was most reluctant to do so. According to Cannon, McGowen gave "friendly but biting" criticism to executive encouragement to make steelhead a game fish. At one point during the 1969 Legislative Session, Cannon disclosed he had "pleaded, yes, pleaded with John McGowen on a two-hourlong telephone conversation to give steelhead a game fish recognition". 47

The Governor's assistant worked the other side of the political fence in efforts to move the inflexible sports people to accept a compromise. At midsession, Cannon called a meeting with Senator Elfstrom, Dan Holm (sportswriter for the Oregonian), and others. The purpose of the meeting was to discuss Senator Elfstrom's Senate Bill No. 406. This bill was designed to give the commercial industry an incidental steelhead catch, but "minimize" the catch. At this point in time, Connie McCready and her supporters were still pushing for the Game Commission amendments. None of the sport fish interest groups had knowledge of $\mathrm{SB} 406$ until Holm was invited to the meeting by Cannon.

Connie McCready was visibly upset when Holm notified her of the meeting and, SB 406. As Cannon noted, HB 1302 was "her baby". However, Elfstrom accomodated to her feelings by agreeing not to attempt passage of his bill unless hers had been hopelessly lost.

The passage of Elfstrom's bill appeared "good", according to the Governor's assistant. He noted that it would be rare if a committee

\section{Ibid.}


chairman were not able to move his bill from a committee. Moreover, the Oregon Senate is a club and there was $m l y$ one senator from a strong commercial fishing area. This senator had agreed not to actively oppose Elfstrom's bill, but to register his "NO" vote in the Senate. Therefore, SB 406 was a reserve measure, to be used if necessary. 48

Clearly, the strategy of the executive department was to persuade and use a little leverage if necessary to get opposing sides to accept a common ground. Cannon's meeting with Senator Elfstrom and sports writer Don Holm was an example of motivating sports groups to compromise. Although the Governor's strategy was to use $\mathrm{SB} 406$ as a lever to prod sports interests, there was a problem in finding a suitable carrot and stick to use on the industry. Cannon appealed to Bumble Bee to maintain a good image of the industry by accepting a compromise. That approach, as Cannon explicitly stated, was a railure. An industry located in Astoria is respected in Astoria. The company president's attitude was "Heroes at home, bastards elsewhere, so what!"49

To accomplish the executive goal of designating steelhead a game fish, Tom McCall's assistant met often with both sides. The executive lobbying effort was consistent and insistent, but low key. "We wanted a compromise, one that would not be completely ineffective- generally, our approach was - How may we help? We assumed a positive stance and exchanged information. $" 50$

Cannon kept reflecting this attitude: "impress upon the committee

${ }^{48}$ Interviews with Cannon, op, cit., Oct. 14, 1969 and JuI. 26,1972. 49Ibid.

50 Ibid. 
that the poople of the State of Oregon would like a protection of this fish - it cannot be subjected to heavy commercial fishing when it is a game fish."

The unexpected came on the afternoon of April 29. Bugas approached Cannon and said: "I am prepared to offer a solution ... I need your support. 151

Cann on took the bill to Tom $\mathrm{McCa}$ al and recommended support. Cann on remarked:

This was with one hour to go before the committee meeting. It was a difficult decision. If we had not made the decision to support it-mow could we justify that? At that stage it was an opportunity to get something. On the other hand, I was in the soup. Connie would be very upset with me. As it turned out, she would rather have the bill defeated than let it go through. But, we wanted some positive effort to recognize steelhead as a game fish. We could not encourage its use as a canning fish. We were surprised about the compromise because the industry had not indicated they were willing. to change the status, and we had kept our correspondence going continually with both sides all along.

We were faced with the politics of the possible. The commercial interests were nore willing to compromise, as they generally are. The sports groups, would most often, rather hold a position and lose. They would rather fight. and even lose, rather than compromise. 52

Cannon listed the major factors responsible for the passage of the compromise legislation:

1. The unwillingness of Connie McCready to compromise.

2. Support by the Governor for steelhead as a game fish.

3. The forthright position of the Oregon Fish Commission on administer-

51 Ibid.

52 Ibid. 
ing the incidental catch.

4. Defeat of McCready's "pure" bill.

5. The willingness of Chairman McKenzie to keep the committee actively working for a compromise when time was short and nearly all concerned had lost hope of a compromise.

6. The executive's quick decision at the eleventh hour; Governor McCall decided that a chance to obtain something was at hand. 53

POLITICS OF THE REAL AND THE IDEAT,

The passage of the bill was another illustration of what could be termed the "politics of the ideal" meeting and clashing with the "politics of the real." From this confrontation came political and legislative change. The political world of the industry, Representative Heard, and the executive department was the politics of the possible. These politicians actively sought "real" possibilities. .

The sponsor of $\mathrm{HB} 1302$ and her supporters followed the politics of the ideal. Possibilities were less important than the search for the absolute--the clear cut moral issue that was not open to compromise. Consdquently Connie McCready was very unhappy with the bill after the Heard amendments were approved. Steelhead were placed in a "never-never land": in between, neither food fish nor, really fully game fish. Yet steelhead were "recognized as game fish." 54 Whereas, the sportsmen were upset about the vagueness, the Governor and the industry were unruffled by ambiguity. For industry taking steelhead from the food fish

\section{${ }^{53}$ Ibid.}

${ }^{54}$.State of Oregon, Senate Fish and Game Committee Minutes, 55th Reguler Session, (Salem: Oregon State Archives, 1969) May 12, 1969; p. 16 . 
catagory and putting it somowhore botwoon food and game fish was not illogical. It was a political necessity. The real need was to give just enough to secure support from the swing member in the committee and to thwart any future initiative. The compromise reflected a realistic appraisal and an adjustment to political necessity.

HOW THE GROUPS VIEN THE BILL

Ted Bugas gave his opinion of HB 1302 in his testimony before the Senate Fish and Game Committee:

There has been a considerable amount of testimony to the effect that this is a compromise bill. To the effect that the language is not the language Representative McCready had in her original bill. [sid This of course is true-it is a completely different bill. I think a misnomer has grown with regard to the definition of this bill. It is said to be a compromise between the commercial and the sports users of this resource: This isn't actually true, in that there is no place the commercial people had to go. It was a matter of give---there was no chance of a benefit approving [sic] to the commercial industry as a result of this bill or any like it. The only possible advantage there is to our industry, and the people for whom I speak, in a bill such as the one before you, or any bill which would make steelhead wholly, or more so, a game fish in the State of Oregon-- that already in fact [sic] is - would be that the harassment and the criticism for the commercial use of this animal would be minimized or would cease...

It is a very difficult thing to come up with a very brief amendment or even a complicated amendment which would do the job that I think these amendments do. For one thing, they say in the commercial code that steelhead is recognized as a game fish-- and they recognize this primarily; it does not do so exclusively. There has been some objection to this today. We recognize this, but we think it is the anly workable way that you can leave the Fish Commission [sic] still "regulate" the incidental take...

Now, to say that this amendment does nothing is not true. Many commercial fishermen out on the river wish that it did nothing. They fought vigorously against my most long-winded 
argument, to get me to not compromise. Yet, I think [sic] in the best interest of the commercial industry and the majority of the sportsmen in the state of Oregon, it is in our best interest to agree to some sort of modification of the Oregon laws that will allow something like this. 55

The Oregon Wildilife Federation basically agreed with the commercial industry:

Our organization has been on record for many years; in favor of legislation to make steelhead a game fish. We realize that there are numerous problems which must be solved before this can be accomplished. We also recognize that House Bill No. 1302: in its present amended form fails to solve all of those problems. However, its adoption would express the intent of the Legislature, and would make steelhead a game fish. 56

The Izaak Walton League viewed the bill in the following manner:

Without a cleaning-up of the wording, we cannot accept this bill. This bill would only muddy the waters. Again, I repeat, we want:

I. Steelhead named in the game fish code and removed as a food fish.

2. Instructions to minimize the catch of steelhead trout in the commercial harvest.

3. Legislative intent to be clearly spelled out to avoid future misinterpretations. 57

The Association of Northwest Steelheaders gave their views:

This amended version to $H B$ steelheaders as a compromise. It in no way resembles the original intent of the bill. It is merely a maneuver to trick the sportsmen into believing that a solution to the steelhead issue has been enacted. The bill you have before

\footnotetext{
55 Ibid., May 12, 1969, Exhibit F.

56 Ibid., May 12, 1969, Exhibit C.

57 Ibid.; May 12, 1969, Exhibit D.
} 
you does not guarantee the sportsmen of any reduction to the commercial incidental catch of steelhead trout. 58

The bill's sponsor gave her reaction to the bill: '

I would only comment that the awkwardness of my position today can be explained by pointing out that all of the original language of the bill had been stricken and that four of the five committee members had voted consistently against the bill and opposed subsequent proposed compromise amendments. We have been blocked, stalled [sic] and postponed [sic] and out-maneuvered for three months, by a small but most efficient lobby. I will be watching with great interest to see how your committee fares. Time is running out, and this of course is the objective, but I would hope that you could see fit to clarify the definition of a steelhead somewhat. [sic] Right now, it is rather cloudy--in a sort of never-never land - according to the attorney's opinions.

In response to a question from Senator Ouderkirk whether she would like to call the bill back in its original form. Representative McCready replied:

At this point, I don't really know. I am willing to see it in any form that will stop the fighto- in any form that will prevent the initiative. I know neither side is ever going to be absolutely happy, but I am willing to accept almost any compromise. I do feel that the definition should be clarified. If it is believed by some attorneys to be named a game fish this way --and by others it isn't, [sic] there shouldn't be any objection to some clarifying language. If "minimize" would be an easier word than "regulate", it would be my feeling that [sic] -I have all of the confidence and faith in the world in the Fish Commission and I think that Mr. Schoning is one of the most competent of men, and I have a tremendous admiration for him. But commissions do change and interpretations change, and I think that anything. that we put into law to make it easier to understand would be advantageous. $5 \overline{9}$

58Ibid., May 12, 1969, Exhibit (E).

59 Ibjd., May 12, 1969, p. 16. 


\section{ACCOMPLISHMENTS}

The major accomplishments of the commercial industry were:

1. The word 'regulate' not 'minimize' was used to guide the incidental catch. 2. The word 'optimum' was put into the bill, and the Fish Commission was authorized to 'optimize' commercial fishing. This was a clear gain for the industry. (As Bugas noted, the use of the word 'optimize' relative to commercial fishing and the word 'minimize' relative to the incidental catch of steelhead would have caused a schizophrenic administrative policy for the Fish Commission, if both words had been inserted into $\mathrm{HB} 1302$ on Apri1 29, 1969). 60 As it was, the words 'regulate' and 'optimum' of the Heard amendments were passed without modification by a majority vote of the committee. 3. The word 'steelhead' was left in the commercial code as provided in the Heard amendments; and was not included in the game code as provided by the original draft of HB 1302 . Administration of the incidental catch remained with the Fish Commission-not the Game Commission (which is more sympathetic to its game conscious constituents).

Game fish supporters gained recognition of steelhead as a game fish. They also reduced the catch of steelhead permitted to commercial interests. Although the reduced catch was not a sharply reduced one, for the first time, industry was forced to give enough to make steelhead a sport fish. The sportsmen and the conservationists did not gain either a minimized catch or a regulation of the catch by the Game Commission. They gained a little and lost a little.

${ }^{60}$ Interview with Bugas, Sept. 10, 1969. 
CHAPTER VI

EVENTS (1969-1974)

\section{THE FIRST FIVE YEARS}

After the passage of $\mathrm{HB} 1302$, the game fishing fraternity adopted a "wait and see" attitude. In 1969, 1970 and 1971 the comerclal fishing winter season incidental catch on the Columbia was approximately 4,000 fish a year. Prior to the passage of the bill commercial fishermen caught approximately 8,500 fish per year. ${ }^{1}$

Generally, HB 1302 provided only marginal protection for steelhead. The mesh restrictions used by the Fish Commission from 1969 to 1975 to accomplish the purpose of the bill to "regulate" the incidental catch did not adequately remove steelhead from commercial fishing. The real problem was--and still remains--the intermingling of salmon and steelhead. As Game Commission Staff Biologist R. C. Sayre phrased it in 1972: "In attempting to reduce this catch with $\mathrm{HB} 1302$ we are between the rock and the hard spot."2 In addition to the problem posed by the incidental catch, there was and still is the basic incompatibility between sport and commercial fishing on the Columbia. When the gillnets go into the water, they sweep up fish and scatter large numbers. of them. Sportsmen characterist-

$1_{\mathrm{HB}} 1302$ did provide limited protection to the foreward portions of certain groups of the summer run. Interview with $R$. C. Sayre, Staff Biologist, Oregon State Game Commission, interview held at the Game Commission, Portland, Oregon, Oct. 26, 1972. 
ically pack up and go home when the gillnets go into the water.

As indicated, the winter season incidental catch of steelhead in 1972 was approximately double the 4,000 fish taken in each of the winter seasons of the three previous years. ${ }^{3}$ Sportsmen were deeply concerned with this increase and began to organize to consider the problem during the 1973 session of the legislature.

In the years following 1969 the political influence of sports fishermen increased. During 1971 they canvassed legislative districts in opposition to state lawmakers who voted with the commercial industry in 1969. They claimed to have contributed to the defeat of former State Senators Inskeep of Oregon City and Jack Bain of Portland. They helped to defeat former State Representatives Frank Roberts, Bill Bradley and Marvin Hollingsworth, all within Multnomah County. However, they had no luck in defeating many-term legislator Grace 0. Peck. ${ }^{4}$

Sports fishermen were active in other organizational efforts to press their interests. In November of 1970, the Association of Northwest Stee1headers signed an agreement merging the organization with the national organization, Trout Unlimited. After the merger, Steelheaders' membership doubled, creating the largest sports fishing and conservation group in the Pacific Northwest. This new organization hired (at the state level) a full-time salaried director and secretary, as well as a part-time secretary. The former organization had only a volunteer director and a

3 Walter McGovern, (former) Oregon President, Northwest Steelheaders Council of Trout Unlimited, interview held on the telephone, Portland, Oregon, Nov. 13, 1972.

${ }^{4}$ Larry Gibson, member Sandy River Chapter, Northwest Steelheaders Council of Trout Unlimited, interview held on the telephone, Portland, Oregon, Nov. 20, 1972. 
part-time salaried secretary. ${ }^{5}$

THE 1973 SESSION

During the 1973 session of the Oregon Legislature, the game fishermen were quite active. State Senator Vernon Cook from East Multnomah County introduced a package of bills: Senate Bills No. 92 through 96, and Senate Bill No. 409. ${ }^{6}$ Another bill, House Bill No. 2652, was introduced at the request of Governor McCall. 7

SB 94 and SB 409 became law. SB 94 gave striped bass game fish status. SB 409 as introduced called for a change in composition of the Oregon Fish Commission to include representatives of sports interests and the general public. However, the original version of the bill was changed at the request of the commercial industry. ${ }^{8}$ The bill as passed simply directed the Fish Commission to put "emphasis" on recreational and aesthetic benefits of Oregon's fish resources. 9

SB 92 and HB 2652 came close to passage only to die after much maneuvering. SB 92 would have closed the Columbia to commercial gillnetting from February 1 to June 1 each year. The bill received a one vote margin "do pass recommendation" from the Senate Agriculture and

${ }^{5}$ Interview with McGovern, Nov. 13, 1972, op. cit.

6 Robert Halloway, Chief Information and Education, Oregon State Game Commission, interview held at his office, Portland, Oregon, Aug, 2, 1973.

7 Don Holm, "Northwest Steelheaders's Group Now Backs McCalls Merger." Oregonian, 28 May, 1973, p. 3. cols. 1-8.

${ }^{8}$ Carey Starzinger, (former) Oregon President, Pacific Northwest Steelheaders Council of Trout Unlimited, interview held at the Monte Carlo Restaurant, Portland, Oregon, Sept. 17, 1974.

9 Journals and Calendars of the Senate and House of the Fifty-Seventh Legislative Assembly, Regular Session, Beginning, January 18 and Ending July 16, 1973, (Salem: 1973) p. C-135. 
Natural Resources Committee on March 29, 1972. However, the "swing vote" reconsidered causing the death of the bill. 10 HB 2652 would have merged the Fish and Game Commissions. On June 23, 1973 it was suddenly moved out of the Joint Ways and Means Committee when Co-Chair man Holmstrom, a strong legislative supporter of comercial fishing, was absent from the committee. The bill passed the House, only to die in the Senate late in the session, creating bitter outbursts from Governor McCall and Senator Holmstrom. 11

Clearly, events within the 1973 session were more favorable to the sports use of the Columbia's fishing resource. The commercial lobby was still strong, although no longer the relatively unchallenged force it was when the industry lobby was instrumental in amending HB 1302 in 1969.

\section{RECENT TRENDS}

The sportsmen did not cease their efforts when the legislature adjourned. Early in 1974 they attacked the incidental catch provision of $1 \mathrm{HB} 1302$ with an initiative designed to ban the commercial sale of steelhead. Ballot Measure No. 15 was sponsored by Save Oregon's Rainbow Trout, Inc. (S.O.R.T). This group provided an umbrella organization for politically active sports fishing interests groups. 12

A major sponsor of the initiative petition was Governor Tom McCall.

10 The "swing vote" was again Fred Heard, a member of the Senate. Don Holm, "N.W. Steelheaders Group Now Backs McCall merger," Oregonian 28 May, 1973, p. 3. cols. 1-8.

${ }^{11}$ Harry Bodine, "The Bumble Bee Lobby: Sports-Commercial Fish Fight Adds Late Spark, "Oregonian, $8 \mathrm{Jul}$. 1973, sec. F, p. 6, cols. 1-4.

12 Interview with Starzinger, Sept. 17, 1974. 
Other sponsors included representatives from the mass communications media, outdoor organizations, college students, political figures, and the Oregon Wildlife Commission. The political personalities Included Robert Straub (then candidate for Governor), Portland City Commissioner Connie McCready, State Senator Fred Heard and others. 13

On February 26, 1974, the commercial fishing organizational equivalent of S.O.R.T., Salmon For All, Inc., challanged the original title of Ballot Measure No. 15 in Marion County Circuit Court. ${ }^{14}$ Commercial fishing lost the court fight; the industry was obliged to pay court costs and the legal expenses of their sports fishing opponents--twelve to fifteen thousand dollars. 15

Approximately a month prior to the election, the industry waged an extensive radio, television, billboard and newspaper campaign to defeat the initiative. The theme was "SOMETHING'S FISHY- VOTE X NO ON 15". The industry focused on projected bad side effects of the measure. An advertisement in the Oregonian on November 3, 1974, listed fifteen reasons for a "no" vote. Some examples:

Will Measure 15 save steelhead? Not a single fish. . .

Would measure 15 tend to destroy Oregon's century-old fishing industry? Yes! It would be one more burden purposed upon Oregon's most over-regulated, restricted, harrassed, home-state industry.

Then who gets hurt by Measure 15?

${ }^{13}$ Save Oregon's Rainbow Trout, Inc., "Initiative Petition, State of Oregon," (Portland: n.d.) Zerox of petition N.00000.

14"Circuit Court Upholds Steelhead Initiative," Oregon Journal, 2 Oct. 1974, p. 7, cols. 7-8.

${ }^{15}$ Interview with Starzinger, Sept. 17, 1974. 
The non-Indian commercial fisherman and you. If 15 passes, the state makes the fishermen "donate" these fish--at his own expense. Then the state has to process and distribute the fish-mat your tax expense. You can count on an expanded bureaucracy. 16

In spite of cxtensive use of mass media advertsenents in opposition to the measure, it was approved by the voters by a vote of 352,336 to $200,996 .^{17}$

Ballot Measure No. 15 obtained a favorable vote because the proponents were politically astute and fortunate enough to receive formal endorsement from the Democratic Party of Oregon. Although the Republican Party took no stand, Republican gubernatorial candidate Victor Atiyeh supported it and Republican Governor McCall appeared on television and radio to give support to the measure. The Democratic Party of Oregon and the Oregon Wildlife Commission provided the opportunity to send mailed statements of endorsement to many persons on the mailing lists of the two organizations including registered Democrats, fishermen, and hunters. On December 5, 1974, the provisions of Ballot Measure 15 went into effect. The measure provided that steelhead incidentally caught by gillnetters would be distributed by the Wildlife Commission to state and charitable institutions. 18

In addition to losing. the campaign against Ballot Measure 15, commercial fishing inserests lost a powerful legislative guardian of their interests. State Senator William Holmstrom was removed as Senate Majority Leader by the Senate Democratic caucus prior to the general

${ }^{16}$ Oregonian, 3 Nov. 1974, p. A 20, cols 5-8. (advertisement). 17"How Oregon Cast Its Ballot," Oregonian, 6 Nov. 1974, p. 1, cols. $1-3$.

${ }^{18}$ Lloyd Smith, Information Expediter Oregon Wildlife Commission, Portland, Oregon. Interview held over the telephone Nov. 8, 1974. 
election ${ }^{19}$ and was subsequently naxrowly defeated for re-election. Holmstrom's defeats were tied to repeated controversles over misuse of power. He was also severly criticized for serving as a paid employee of ALUMAX aluminum plant. 20

THE INDIANS WIN IN COURT

Beginning in 1969 the Indians affected by treaties won court orders to protect their fishing rights and to give them a significantly increased percentage of the catch. Since Oregon Federal District Judge Robert Belloni ruled in 1969 that the Indians had a right to a "fair share of the catch," only a few court orders were necessary to insure his decision. 21 This was not the case, however, in the State of Washington. Washington unlike Oregon, had long recognized steelhead as a game fish. The Game Commission of that State had enjoined netting by Indians. 22 However, on November 19, 1973 the Supreme Court ruled that the State of Washington had no right to prevent Indian gillnetting of steelhead. The court stated:

If hook and line fishermen now catch all the steelhead which can be caught within the limits needed for escapement, then that number must in some manner be fairly apportioned between Indian net fishing and non-Indian sports fishing, so far as that particular species is concerned. What formula should be

19

Interview with Starzinger, Sept. 17, 1974, op. cit.

20"Demos Lose Leader, But Pad Legislature," Oregon Journal, 6 Nov. 1974, P. 15, cols. 5-8.

${ }^{21}$ George Dysart, Assistant Regional Solicltor, Department of the Interior, interview held at Bonneville Power Building, Portland, Oregon, Sept 9, 1974.

22 Ibid. 
employed is not for us to propose. 23

The formula was declared on February 12, 1974 by Washington Federal District Court Judge George Boldt, who provided that the Indians could catch 50 per cent of the off-reservation fish (The 50 per cent figure did not include fishing on the reservation or ceremonial and subsistence fishing off the reservation). 24

Following determination of the formula on May 10, 1974, Judge Belloni ruled that:

The Indian treaty fishermen are entitled to have the opportun: ity to take up to 50 per cent of the harvest of the spring Chinook salmon run destined to reach the tribes usual and accustomed stations. Except insofar as amended here. The 1969 judgement remains in full force and effect. 25

The Oregon Fish Commission has interpreted Judge Belloni's order to apply to more than spring chinook. For example, it allowed the Indians to catch up to 50 per cent of the upriver fall chinook salmon' run on the Columbia in 1974. 26.

${ }^{23}$ Supreme Court of the United States; Syllabus Department of 'Game of Washington v. Puyallup Tribe, Inc., et. al., No. 5, 72-481 and 72-746 (Nov. 19, 1973).

${ }^{24}$ American Law Division, to Honorable Lloyd Means, the Library of Congress, Congressional Research Service, Washington, D. C., Feb. 12, 1974.

25 Civ11 No. 68-409 Order Amendtug Judgement of October 10, 1969 civil No. 68-513. U. S. District Court of Oregon, Filed and entered May 10, 1974.

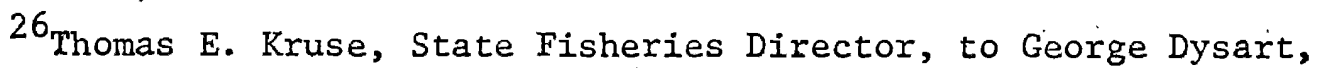
Assistant Regional Solicitor, Department of the Interior, Portland, Oregon, Aug. 7, 1974, personal files of George Dysart. 
The court orders have changed the situation on the Columbia to a marked degree. In 1969, Judge Belloni stated there were three types of fishing: commercial, sport and that done by Treaty Indians: However, in terms of fish currently allocated, there are two categories of users: Indians and non-Indian. 
The Columbia River has both great value as a rearing environment for anadromous fish and as a significant source of electric power. Consequently, conflicts over the uses of the river's resources continuously occur. There have been often heated--sometimes violent-rclashes of values over the use of the river's fish. Currently, the open conflict is most intense between anadromous fishing groups. The conflict over steelhead has been pronounced for several reasons, the chief of which is that steelhead are highly prized for sport fishing. These robust fighters mingle with salmon and clashes are unavoidable because the gillnets scatter the fish and catch steelhead incidentally. Many local sportsmen want to remove the nets from the river.

The numbers of fish available on the Columbia has declined. The reduction began following the height of the runs in the 1880's. This reduction continued steadily from the 1930's and became more acute after 1956-due in large part to dams. This decline of the resource has occurred as the population of Oregon has grown. Moreover, to compound the problem, Indians have been obtaining an increasingly larger share of the fish since the Belloni Court order of April 23, 1969.

Recreational demand for steelhead is continually growing. The value of food fish is climbing and remains proportionately high. Increases in human population maintain the high price for commercial salmon as the fish runs decline due largely to the effects of dams. Perennial user group struggles over salmonoids have traditionally 
been settled in one of three ways: by initiative petition, legislative action, or court order. The initiative process legalizes victories and defeats through a win or Iose decision. On the other hand, the Legislature often develops compromises and not simply pure victories or defeats.

The Legislature is an institutional arena for adjusting these confrontations over values. However, this arena is often merely a temporary means of deciding interest group tournaments. Commercial and sport fishing contests are only one of the many conflict areas with which legislatures must grapple. The Legislature registered its decision in the sports industrial fish conflict under study through passage of $\mathrm{HB} 1302$. The bill itself was only one of a series of attempts to reconcile game angling and fishing for commerce. Moreover, the new political equation created by $\mathrm{HB} 1302$ had a short life. It predominateIy satisfied one side because it was designed and dictated by that side, i. e., commercial fishing.

The passage of the bill is a fascinating study of political influence. The fishing industry capitalized on its superior access to the legislative process and machinery. The fish packers' Iobby was successful in gaining influence with the committee chairman and the majority of the members of the House Fish and Game Committee. The Iobby was especially talented in obtaining the crucial undecided vote within the committee.

The industry had many advantages over the game fish proponents in the Legislature. The commercial lobbyist Ted Bugas maintained a superior information service. He used a soft-sell persuasive relation- 
ship very successfully. He was involved in the process that brought subile rewards to the swing vote in committee. He developed and projected a positive image of himself and those he represented. Finally, he was more organized, better financed and had a strong coalition behind him. Of great importance was his ability to compromise when necessity demanded it.

The industry strategy to fight the bill's passage, then to push a compromise in the waning days of the session, was successful. On the other side, opponents embraced a rather rigid antipathy to compromise. However, the coalition of groups adhering to this stance did not remain together. One group, the Oregon Vildlife Federation, abandoned this strategy after the commercial lobby softened its position slightly. However, most sports fishermen and other sports groups opposed HB 1302 as amended.

Each of the two opposing coalitions pursued its strategy vigorousIy. The commercial lobby's strategy produced the best results. Its strategy turned on gaining the uncommitted Fish and Game Committee member's crucial vote. The sportsmen and their allies nearly achieved victory; paradoxically, however, steadfastness of stance brought them close to victory and then caused them to Iose their grasp on their objective. The sportsmen had developed some influence on legislators in the 1969 session (because of their growing number of followers), but they lost the game because they refused to negotiate at a crucial time when a somewhat less stringent stance might have brought victory.

Besides inflexibility, the sportsmen lacked a cohesive, well structured and funded organization, one capable of supporting a lobby- 
ist. Ihey had too few sources of credible information and persuasion. Passage of the bill resulted in gains and losses to both sides. Packing interests calculated and yielded just enough to recognize steelhead as a game fish. In the process, they lost some fish, but not more than a few thousand. They were successful in removing a strong impetus for an immediate initiative by game fish interests. The bargain the industry achieved vias the best possible at the time. Moreover, the concentration of the sportsmen on steelhead diverted attention at least for the time being, from salmon, the industry's major concern. I

With the passage of $\mathrm{HB}$ 1302, the sports-conservation alliance gained a weak recognition of steelhead's game fish status and a marginal reduction of steelhead. However, it narrowly lost what it strongly desired, a stringent bill that took the profit motive out of commercial fishing for steelhead. Sportsmen became frustrated and angry and felt that the initial bill had been drastically altered and the alteration forced on them.

The sport fishing interests witnessed for the first time in 1969 the culmination of a long sports campaign to make steelhead a game fish. HB 1302 left the committee in its amended form because the gilnet fishermen "had their backs to the wall." OnIy the Columbia River remained as their river territory. Therefore, they had to forge a victory from their threatened position. They used their legislative advantage well-an experienced, effective lobby. In 1969 the legislative arena was not jet a sportsmen-conservationist's area of strength. The margin of industry success was thin, but the slight edge provided a commercial fishInterview with Starzinger, sept. 17, 1974. 
ing success.

Although the sportsmen narrowly lost their objective, the historical trend was (and currently remains) in their favor: The more numerous, smallex-catch fishermen have consistently banded. together to force the less numerous, but larger-catch fishermen from the river. At the common table the diners with the heaviest appetites upset the other guests. This occurs even though the users taking the smaller bites consume the great majortty of the resource.

Gillnet fishermen banded together with sportsmen in 1948 and they drove the trap and seine owners from the Columbia waters. In a manner reminiscent of a Monopoly game, the less powerful players were removed from the game as the winning members began to shape their strategy for a struggle for exclusive control. The sportsmen have now removed commercial fishermen from the steelhead runs as both sport and commercial fishermen have had to accept the reality of Indian fishing rights on steelhead and other species of fish.2

Events since passage of $\mathrm{HB} 1302$ clearly indicate the temporary nature of 1302 . Two years after passage of the bill, the embers of the controversy were again aglow. During the 1973 legislative session sportsmen were able to garner sufficient support for passage of two minor bills. In 1974 they went to the public with a ballot measure that was almost a replica of the unsuccessful amendments proposed by the Game Commission to HB 1302. The measure passed and steelhead are now legally banned for sale, except by Indians protected by the Federal Courts.

2 Ibid. 
The remarkable fact of the steelhead fight was the small number of fish that were contested. Former Chairman of the House Fish and Game Committee, Rod McKenzie, commented in 1969 that the fight was over two thousand fish. He was referring to 30 per cent of approximately eight thousand winter season steelhead caught by commercial fishermen. ${ }^{3}$

McKenzie further characterized the 1969 House Fish and Game Committee as the "committee on emotions". 4 The central fact emphasized by his observations was the qualitative nature of the conflict. The fight was primarily over allocation of values, not over quantities of fish. The steelhead fish fight in 1969 which focused on HB 1302 was an important turning point in a balance of power between sport and commercm ial fishing interests. If $\mathrm{HB} 1302$ had passed two years earlier it would have been hailed by sport fishing groups as a major victory. Instead, the passage in 1969 of $\mathrm{HB} 1302$, as amended, was a victory though a narrow one, for the commercial lobby. However, by 1974 with the passage of Ballot Measure No. 15, the industry had lost the steelhead war.

Unfortunately, the sportsmen may have also lost the war. Unless drastic action is taken by government and the public, within a few years the salmon and steelhead runs on the Columbia may be a thing of the past.

3 "House Floor Debates" Tape Recording Number 18 RGI6 72 A-93 55th Session, 1969, Siate Archives, Salem; Oregon. n. d.

4 Ibid. 
SOURCES CONSULTED

BOOKS

Blair, George S. American Legislatures: Structures and Processes. New York: Harper and Rop Publishers, 1967.

Bullard, Oral. Crisis on the Columbia. Portland: Touchstone Press, 1968.

Cooley, Richard A. Politics and Conservation: The Decline of the Alaska Salmon. First edition. New York: Harper and Row Publishers, 1963.

Dodds, Gordon Barlow. The Salmon King of Oregon: R. D. Hume and the Pacific Fisheries. Chapel Hill: University of North Carolina Press, 1963.

Donaldson, Ivan J. and Cramer, Frederick C. Fishwheels of the Columbia. Portland: Binfords and Mort, 1969.

Holtzman, Abraham. Interest Groups and Lobbying. New York: MacMillian Co., 1966.

Key, V. 0., Jr. Politics, Parties, and Pressure Groups. Fifth edition. New York: Thomas Y. Cromwell Company, 1964.

Mahood, H. R. Pressure Groups in American Politics. New York: Charles Scribners Sons, 1967.

Sagner, George P., Ed. The Statutes at Large, Treaties, and Proclamations of the United States of America from December 5, 1859 to March 3, 1863. Boston: Little Brown and Company, 1863. (Reprint edition. United States Statutes At Large, Volume 12. Buffalo: Dennis \& Co., Inc. August, 1961).

Schriftgiesser, Karl. The Lobbyists: The Art and Business of Influencing Lawmakers. Boston: Little, Brown and Company, 1951.

Truman, David B. The Governmental Process. New York: Alfred A. Knopf, 1960.

Ziegler, Harmon, and Baer, Michael. Lobbying: Interaction and Influence in American State Legislatures. Belmont: Wadsworth Publishing Co., 1969. 
PERIODICALS

Pacific Fisherman Yearbook International, Vol. 60, No. 2 (January, 1962), p. 66 .

"Sport vs. Business," The Oregon Voter, Vol. 16, No. 1 (January 4, 1919), pp. $528-30$.

State of Oregon, Journals and Calendars of the Senate and House of the Fifty-seventh Legislative Assembly, Regular Session, Beginning January 13 and ending May $23,1969$. Salem: 1969.

State of Oregon, Journals and Calendars of the Senate and House of the Fifty-seventh Legislative Assembly, Regular Session, Beginning January 18 and ending July 6, 1973. Salem: 1973.

"Unofficial Government: Pressure Groups and Lobbies," The Annals of the American Academy of Political and Social Science, Vol. 319 (September, 1958), pp. 63-72.

\section{PAMPHLETS, REPORTS AND PROCEEDINGS}

Association of Northwest Steelheaders, Help Preserve Your Steelhead and Salmon Runs, Portland: (leaflet) no d.

- Help Save Our Steelhead, Portland: (unpublished letter) n. d.

- Portland Chapter, Steelhead Trout Game Fish---or---Food Fish,

50 Years of Indecision, Portland: (pamphlet) n. d.

- Statement of Policy and Goals, Portland: (mimeographed) n. d.

Bureau of Commercial Fisheries, Commercial Fisheries of the Columbia River and Adjacent Ocean Waters, Seattle: FIR Reprint 42, From Fishery Industry Research, Vol. 3, No. 3. n. d.

Fish Commission of Oregon, Administrative Order FC-211, Portland: July $24,1970$.

- Analysis of Differences in Fish Counts at Columbia River Dams 1957-65, Portland: January, 1966.

- Biennial Report, 1966-1968, Portland: 1968.

- Columbia River and Tributaries Catch of Salmon and Other Food Fish in Pounds Round Weight by Month for 1971 Landed in Oregon, Portland: Apri1, 1972. - Commercial Landings With a Mesh Restriction (1970-72), June 14, 1972 . 
- Historv of the Oregon Fish Commission, Portland: n. d.

- Information and Education Section, 1969 Legislative File, HB 1302 ,

Portland: 1969.

- News Release: A Sumary Report to the Governor on Steelhead Landings by Edward G. Huffschmidt, Chairman of the Fish Commission, State of Oregon. Portiand: August 29, 1969.

- News Release: Winter Commercial Fishing Season Explained, Portland: February 17, 1969.

- Robert W. Schoning, Director, Speaking for Columbia Basin State and Federal Fisheries Agencies, Tri-State Governors Meeting, Nitrogen Supersaturation Problems on the Columbia and Snake Rivers, Portland: March 23, 1971.

- Some Factors Influencing the Trends of Salmon Populations in Oregon, Clackamas: Reprint from Transactions of the Fifteenth North American Wildlife Conference, March 9, 1950.

- Memorandum: Staff Proposals for Commercial Fishing Regulations for the Columbia River in 1970, Portland: September 8, 1969.

- 1968 Status Report of the Columbia River Commercial Fisheries, Portland: 1968 .

- Status Report, Columbia River Fish Runs and Commercial Fisheries, 1938-70; Vol. 1, No. 1, Portland! January, 1971.

- Status Report, Columbia River Fish Runs and Commercial Fisheries, $1938-70,1971$ Addendum, Vol. 1, No. 2, Portland: January, 1972.

- Steelhead a Game Fish Bill (House Bill 1302), Portland: 'June 6, 1969. (Published speech of R. W. Schoning, Director, to Portland

Chapter Izzak Walton.Club, Portland, Oregon.)

- The Effects of a Mesh Restriction on the Catch of Steelhead

During the Columbia River Winter Commercial Fishing Season, 1971 ,

Clackamas: . November, 1971.

- The Effects on Salmon Populations of the Partial Elimination of Fixed Fishing Gear on the Columbia River in 1935, Portland: 1935.

Indian Treaty Hunting and Fishing Rights, Portland, Oregon, (leaflet from Bureau of Indian Affairs), Portland: n. d.

Idaho Wildife Review, Columbia River Commercial Fishing and Its Regulation, Boise: November-December, 1970.

Junge, C. J. "Can We Maintain Our Salmon and Steelhead Runs in Oregon?" Speech delivered at Oregon Wildife Federation, Portland, Oregon, January 13, 1968. (Mimeographed). 
Milwaukie Rod and Gun Club Fish Committee, Boating Report on Pleasure Craft and Their Uses, Milwaukie: (leaflet) n. d.

Oregon State Game Commission, Biennial Report 1971-1972, Portland: December, 1972.

- Proposed Amendments to House Bill 1302, Portland: May 7, 1969.

- Statement of Oregon State Game Commission on House B111 1302 as Amended on May 2, 1969, Portland: May 12, 1969.

- The Good 01d Days: A Review of Game and Fish Administration in Oregon, Portland: (leaflet), 1960.

- The Sport and Commercial Harvest of Recent Columbia River Salmon and Steelhead Runs, Portland: May 16, 1973.

Oregon State University, An Economic Evaluation of the Oregon Salmon and Steelhead Sport Fishery, Corvallis: September, 1964.

Oregon Wildlife Federation, O.W.F. History, Portland: May 23, 1972.

Save Our Salmon and Steelhead, Inc., Initiative Filed to Classify Salmon and Steelhead Game Fish, Portland: August 8, 1963.

- Reference Guide, Factual Information on Sports \& Comnercial Fishing for Salmon and Steelhead in the Columbia River System of Oregon, Washington, and Idaho, Portland: 1963.

State of Oregon, An Outline Study of the Legislature and Legislative Process. Salem: n. d.

- Department of Justice, This Opinion Is In Answer to Questions Presented by Dr. Thomas E. Kruse, Acting Director, Fish Commission of the State of Oregon. Salem: August 22, 1969.

State of Oregon, Office of the Governor, Accomplishments in Conservation, First Two Years of Governor Tom McCall's Administration. Salem: December, 1968.

- Governor McCall's Statement on the Occasion of His Signing of H. B. 1302. Salem: July 6, 1969.

- Office of the Governor, 1969 Report to Outdoor Editors, Salem: August 21, 1969.

State of Oregon, Report of Interim Fisheries Committee to the Fourtysecond Legislative Assembly, Salem: 1943.

State of Washington, Department of Fisheries, Columbia River Commercial Fishing Regulations From 1866 to 1961. Seattle: October, 1961. 
Transactions of the American Fisheries Society, Effects of John Day Dam on Dissolved Nitrogen Concentrations and Salmon in the Columbia River, 1968. Reprint Vol. 99, No. 4, Seattle: October, 1970.

United States Department of Commerce, Historical Statistics of the United States Colonial Times to 1957. Washington, D.C.: 1957.

- National Oceanic and Atmospheric Administration, Spawning Areas and Abundance of Steelhead Trout and Coho, Sockeye, and Chum Salmon

- in the Columbia River Basin - Past and Present. Special Scientific Report - Fisheries No. 618, Washington, D.C.: December, 1970.

United States Department of the Interior, Bureau of Indian Affairs, Indiar Treaty Hunting and Fishing Rights, Portland: June 7, 1973.

- Highlights of United States v. Washington (Civil No. 9213, W. D. Washington) Judge Boldt's Decision on Off-Reservation Indian Treaty Fishing Rights in Northwest Washington, Portland: March 25, 1974.

- The History and Development of the Fisheries of the Columbia River, Washington, D.C.: 1940 .

\section{LEGISLATIVE BILLS}

Oregon, Oregon State Legislature, 1969:

House Bill No. 1302. Declares Salmo gairdneri, commonly known as steelhead trout, to be game fish.

House Bill No. 1302 (Engrossed). Deletes steelhead trout from definition of "salmon" in commercial fishing laws.

Senate Bill No. 406. Classifies steelhead trout as game fish. - 1973: House Bill No. 2652. Merges State Game Commission and Fish Commission of Oregon into State Department of Fish and Wildife.

Senate Bill No. 92. Except for incidental catch, prohibits commercial take of chinook salmon and steelhead trout from Columbia River below Bonneville Dam from February 1 to June 1 of same calendar. year.

Senate Bill No. 93. Adopts compact between states of Idaho, Oregon and Washington for management of anadromous fish, upon ratification of such compact by Congress and by Idaho and Washington.

Senate Bill No. 94. Prohibits commercial taking of striped bass. Removes qualifications on definition of striped bass as game fish.

Senate Bill No. 95. Requires Fish Commission to use all reasonable means to minimize incidental take of steelhead trout, including restrictions on season, gear and area. 
Senate Bill No. 96. Restricts emergency rule authority of Fish

Commission to closures of season or areas.

- 1975: Senate Bill No. 613. Abolishes State Wildife Commssion and Fish Commission of the State of Oregon.

\section{AMENDMENTS - LEGISLATIVE BILLS}

Multnomah Hunters and Anglers, Proposed Amendments to House B111 1302. Salem: n. d.

Oregon Legislative Assembly - 1969 Regular Session, House Amendments to H.B. 1302. Salem: May 2, 1969.

OREGON LEGISLATURE -- JOURNALS, CALENDARS, MINUTES

State of Oregon, llouge Fish nnd Game Committee Minutes, Fifty-fifth Regular Session, Salem: 1969.

Oregon Legislative Assembly - 1969 Regular Session, Final Legislative Calendar Tables and Index, Regular Session, Fifty-fifth Legislative Assembly of Oregon. Salem: 1969.

U. S. SUPREME COURT CASES

Puyallup Tribe v. Department of Game, 391 U. S. 3292 (1968) and 410 U. S. $981(1973)$.

FEDERAL DISTRICT COURT CASES

Sohappy v. Smith, 302 F. Supp. 899, D. Ore. (1969).

United States v. Washington, 384 F. Supp. 312, D. Wash. (1974).

- FEDERAL DISTRICT RULINGS

U. S. District Court Ore. Civil No. 68-409 October 10, 1969. (Xerox copy). - Civil No. 68-409 Order amending judgment of October 10, 1969. - Civil No. 68-409 Order Dissolving Temporary Restraining Order: May 10, 1974. (Xerox copy). 
U. S. Dist. Court Wash. Civil No. 9213 Interim Plan and Stay Order March 22, 1974. (Xerox copy).

- Civil No. 9213 Order appointing Fishery Science and Management Expert March 22, 1974. (Xerox copy).

- Civil No. 9213 Injunction March 22, 1974. (Xerox copy).

- Civil No. 9213 Ruling on Post Motions n. d. (Xerox copy).

- Civil No. 9213 Errata in Interim Plan and Stay Order. n. d. (Xerox copy).

- Civil No. 9213 Errata in Final Decision 非. n. d. (Xerox copy).

MISCELLANEOUS DOCUMENTS

"House Floor Debates," Tape Recording Number 18, R G L 6, 72 A-93, 55th Legislative Session, 1969. State Archives, Salem: n. d.

Intervenor's Response to Petitioners Abstract of Record and Brief. February 26, 1974. (Personal files of Carey Starzinger).

Library of Congress, Congressional Research Service, An Analysis of United States v. Washingtori Indian Treaty Fishing Rights in the State of Washington, Washington, D.C.: February 12, 1974.

Oregon Legislative Assembly, Registration of Lobbyists, Form 142 A 466. Salem: $n$. d.

Response and Brief of Intervenors, Save Oregon's Rainbow Trout, Inc. n. d. (Personal files of Carey Starzinger).

Supreme Court of the United States, Syllabus Department of Game of Washington v. Puyallup Tribe, Inc. etc. al. Nos. 72-481 and 72-746. November 19, 1973. (Xerox copy).

Save Oregon's Rainbow Trout, Inc., "Initiative Petition, State of Oregon," Portland: n. d. (Xerox copy of Petition No. 0000).

\section{LETTERS}

Briggs, Dick, Staff Writer, Herald and News, Klamath Falls, Oregon, to Connie McCready. June 14, 1969. (Xerox copy).

Cannon, Kessler, Administrative Assistant to the Governor, Salem, Oregon, to Emery Albertson. July 21, 1972. 
Galbreth, Jim, Aquatic Biologist, Fish Commission of Oregon, Research Headquarters, Clackamas, Oregon, to Emery Albertson. June 14, 1972.

Hallock, Ted, Oregon State Senator, Portland, Oregon, to Robert J. Peebles. March 28, 1969.

Huffschmidt, Edward G., Chairman, Oregon Fish Commission, to Herbert Lundy, Editor the Editorial Page, The Oregonian, Portland, Oregon. May 5, 1969. (Xerox copy).

Kelley, Allan I., Past President, Oregon Division Izaak Walton League, Portland, Oregon, to Governor Tom McCal1. May 18, 1969.

- Past President, Oregon Division Izaak Walton League, Portland, Oregon, to Emery I. Albertson. May 19, 1972.

Kruse, Thomas E., State Fisheries Director, Fish Commission of Oregon, Portland, Oregon, to George D. Dysart, Assistant Regional Solicitor, Department of The Interior, Portland, Oregon. August 7, 1974.

Lundy, Robert W., Legislative Counsel, State of Oregon, Salem, Oregon, to Connie McCready. January 24, 1969. (Xerox copy).

McCa11, Tom, Governor, State of Oregon, Salem, Oregon, to Rod McKenzie and members of House Committee on Fish and Game. April 29, 1969.

- to Emery Albertson. May 25, 1972.

McCready, Connie, Commissioner of Public Utilities, City Hall, Portland, Oregon, to Emery Albertson. June 5, 1972.

- (Former) Oregon State Representative, Portland, Oregon, Letter to the Editor Hearld and News, Klamath Falls, Oregon. June 10, 1969. (Xerox copy).

McKean, John, Director Oregon State Game Commission, Portland, Oregon, to Steelhead Committee. February 27, 1969.

- Portland, Oregon, to Kenneth Gates. February 4, 1969. (Xerox copy).

Rancourt, Henry R., Legislative Chairman, Multnomah Anglers and Hunters Club, Portland, Oregon, to State Senator Don Willner. May 15, 1969. - to Connie McCready, Portland, Oregon. June 10, 1969.

Straub, Robert W., Treasurer, State of Oregon, Salem, Oregon, to Connie McCready. March 19, 1969.

Sayre, R. C., Staff Blologist Fish Planning, Oregon State Game Commission, to Emery Albertson. June 7, 1972. 
INTERVIEWS

Bugas, Theodore. Executive Secretary Columbia River Salmon and Tuna packers Association, Portland, Oregon. Interview September 10, 1962.

Buker, Robert. (former) President Pacific Northwest Association of Steelheaders, Portland, Oregon. Interview July 5, 1972.

Cannon, Kessler. (former) Administrative Assistant Department of Natural Resources, to the Governor, Salem, Oregon. Interview October 14, 1969 and July 26, 1972.

Collins, Charles. (former) President, Oregon State Izaak Walton League, Portland, Oregon. Interview July 17, 1972.

Cook, Vernon. Oregon State Senator, Gresham, Oregon. Interview August 8, 1973.

Dugan, Jack. Head Information and Education, Oregon Fish Commission, Portland, Oregon. Interview July 27, 1973.

Dugdale, Robert E. (former) Oregon State Representative, Portland, Oregon. Interview July 8, 1973.

Dysart, George. Assistant Regional Solicitor, Department of The Interior, Portland, Oregon. Interview September 9, 1974.

Galbreth, Jim. Aquatic Biologist Fish Commission of Oregon, Clackamas, oregon. Interview July 11, 1972.

Gates, Kenneth. (former) President Pacific Northwest Association of Steelheaders, Portland Chapter, Portland, Oregon. Interview August 5, 1969.

Gibson, Larry. Member Sandy River Chapter, Northwest Steelheaders Council of Trout Unlimited, Portland, Oregon. Interview (telephone) November 13, 1972.

Haley, Wendell. (former) President Oregon Izaak Walton League, Portland, oregon. Interview July 10, 1972.

Halloway, Robert C. Chief of Information and Education, Oregon State Game Commission, Portland, Oregon. Interview September 6, 1972.

Holm, Don. Outdoor Writer, The Oregonian, Portland, Oregon. Interview July 12, 1972.

Junge, C. J. Oregon Fish Commission, Research Division, Clackamas, oregon. Interview July $28,1974$.

Lindstrom, Ross. Secretary of Columbia River Fishermen's Protective Union, Astoria, Oregon. Interview September 3, 1973. 
Lundy, llerbert. Editor, The Oregonian, Portland, Oregon. Interview August $8,1972$.

McCallister, Tom. Outdoor Writer, Oregon Journal, Portland, Oregon. Interview July 12, 1972.

McCready, Connie. (former) Oregon State Representative, Portland, Oregon. Interview August 4, 1969.

McGovern, Walter. (former) Oregon State President, Northwest Steelheaders Council of Trout Unlimited - Oregon Division. Interviews July 15, 1972 and (telephone) November 3, 1973.

Moorhead, George. Vice-President, Oregon Wildlife Federation, Salem, oregon. Interview July 10, 1972.

Peck, Grace 0. Oregon State Representative, Portland, Oregon. Interview August 20, 1972.

Pynn, Allen B. (former) Oregon State Representative, Portland, Oregon. Interview (telephone) July 5, 1972.

Rancourt, Henry R. President Multnomah Hunters and Anglers, Portland, Oregon. Interview August 10, 1972.

Rice, Graham. Range Conservationist, Branch of Land Services Bureau of Indian Affairs, Department of The Interior, Portland, Oregon. Interview April 12, 1973.

Sayre, Robert. Staff Biologist Oregon State Game Commission, Portland, Oregon. Interview October 26, 1972.

Schneider, Phillip. Regional Executive, National Wildlife Federation, Portland, Oregon. Interviews July 17, 1972 and (telephone) October 26, 1972 .

Smith, Lloyd. Information Expediter, Oregon Wildlife Commission, Portland, oregon. Interview (telephone) November 8, 1974.

Starzinger, Carey, (former) Oregon State President, Northwest Steelheaders Council of Trout Unlimited - Oregon Division. Interviews September 17, 1974 and October 10, 1974.

\section{NEWSPAPERS}

"Aged Yakima Is Making Last Fight for Fishing Rights," Oregon Journal, March 21, 1920, p. 10.

"Anglers Group Rebukes Martin," The Oregonian, January 30, 1935, p. 6. 
- "Want to Kill Joker in Salmon Law," Portland Telegram, December 27, 1919, p. 13.

"Ban on Steelhead Sales Imposed," Oregon Journal, January 8, 1974, p. 7. "Biennal Row Over Fish Gear," The Oregonian, January 30, 1935, p. 8. "Big Industry Menaced by Rain Wardens Say," Evening Telegram, December 4, 1913, p. 1 .

"Bill Stalled on Steelhead," The Oregonian, April 25, 1969, p. 14. Bodine, Harry, "The Bumble Bee Lobby, Sports-Commercial Fish Fight Adds Late Spark," The Oregonian, July 8, 1973, Sec. F, p. 6. - "Fish Game Agency Bill Stirs Debate," The Oregonian, July 6, 1973 , p. 1 .

- "House OKs Game Fish Merger," The Oregonian, June 23, 1973, p. 1. - "Steelhead Bill Voted by House," The Oregonian, May 7, 1969, p. 1. (Microfilm).

"Changes Against Game Commission Create Interest," Oregon Journal, May 30, 1919 , p. 15.

- "Made by Sportsmen Bring Official Replies," April 9, 1919, p. 8.

"Circuit Court Upholds Steelhead Initiative," Oregon Journal, October 2, 1974, p. B7.

"Commercial Interests Complain About Use of Schools," The Oregonian, May 3, 1962, p. 19. (Microfilm).

"Court Action Aimed at Steelhead Ballot," Oregon Journal, July 31, 1962, p. 6. (Microfilm).

"Dealers Warned Too, State Assails Indian Fishery," Oregon Journal, March 4, 1966, p. 1.

"Demos Lose Leader, But Pad Legislature," Oregon Journal, November 6, 1974, p. Al5.

"Editorial," The Oregonian, January 24,1948, p. 6.

- The Oregonian, October 11, 1948, p. 10. (Microfilm).

- The Oregonian, September 1, 1962, p. 10. (Microfilm).

- The Oregonian, February 7, 1965, p. f.2.

- The Oregonian, February 28, 1965, p. f.2. 
- The Oregonian, March 24, 1965, p. f.22.

- The Oregonian, March 9, 1966, p. 20.

- The Oregonian, May 8, 1969, p. 40. (Microfilm).

- The Oregonian, May 20, 1969, p. 20. (Microfilm).

- The Oregonian, August 16, 1969, p. 10. (Microfilm).

- The Oregonian, March 18, 1970, p. 34. (Microfilm).

- The Oregonian, April 26, 1973, p. 44.

- The Oregonian, June 6,1973, p. 36.

- The Oregonian, July 15,1973, p. f.2.

- Oregon Journal, August 20,1920, p. 8 .

- Oregon Journal, October 28, 1926, p. 12.

- Oregon Journal, February 3, 1965, p. 10.

- Oregon Journal, October 15, 1970, p. 15. (Microfilm).

"Fish and Game Commissions Do Not Now Exist," Oregon Journal, November 29, 1913, p. 8.

"Fish and Game Merger OKd," Oregon Journal, June 23, 1973, p. 1.

"Fishing Law Dilemma Bared," Oregon Journal, September 20, 1965, p. 1.

"Fishing Rights Trial Sought," Oregon Journal, January 7, 1969, p. 2.

"Fish Row Is Simmering In Political Pot," Oregon Journal, August 19, 1920 . p. 2.

- Trial Will Begin," The Oregonian, August 30, 1962, p. 19. (Microfilm).

-War Looms In Court Action," The Oregonian, August 18, 1926, p. 1. (Microfilm).

"Fishwheel Act May Be Attacked in High Court," Oregon Journal, November 7, 1926, p. 13.

"Four Indian Tribal Leaders Agree to Comply With Columbia Salmon Fishing Ban," The Oregonian, April 26, 1969, p. 14.

"Came Agents Jail Indians," The Oregonian, April 16; 1966, p. 7. 
- Board is Ousted by Governor Plerce," - Oregon Journal, June 17, 1923, p. 1 .

- Fish Bill Fails," The Oregonian, April 12, 1969, p. 19. (Microfilm).

"Governor Names Whole New Game Commission, Ousts 0ld Group," Oregon Journal, January 30,1935 , p. 4 .

"Grange Resists Steelhead Bill," The Oregonian, August 19, 1962, p. 26. (Microfilm).

"Hatfield Bars U. S. Proposal," Oregon Journal, October 14, 1965, p. 1. .. Snubs U. S, Offer to Govern Indian Fishery," The Oregonian, October 14, 1965, p. 28.

Heard, Fred, "Legislative Report: Student Observers are Fun," Hearld and News, April 17, 1969, p. 12.

Holm, Don, "Critics Charge Steelhead Sell-Out," The Oregonlan, May 5, 1969, P. 2. (Microfilm).

- N.W. Steelheaders Group Now Backs McCall's Merger Proposal," The Oregonian, May 28, 1973, p. 3.

"House OKs Steelhead Compromise," Statesman, May 7, 1969, p. 14. (M1crofilm).

"How Oregon Cast Its Ballot," The Oregonian, November 6, 1974, p. 1.

"Huffschmidt, Edward G., "Reduced Steelhead Catch Promised," The Oregonian, May 6, 1969, p. 18. (Microfilm).

Hughes, Harold, "Amended Steelhead Bill Wins 'Do-Pass' Support," The Oregonian, April 30, 1969, p. 1. (Microfilm).

- Fish-Game Unit OK'd by House," The Oregonian, February 26, 1965, p. 1 .

- Senators Send Bill to McCall," The Oregonian, May 17, 1969, p. 1.

- Steeihead Declared Game Fish," The Oregonian, May 17, 1969, p. 1.

- Steelhead Game Fish Label Out," The Oregonian, April 23, 1967.

p. 1. (Microfilm).

"Indians Ask Fishing Spot," The Oregonian, March 9, 1958, p. 27.

"Indian Bureau Opposes Fish Rule," Oregon Journal, March 11, 1966, p. 7.

Fishing Creates Dilemma," The Oregonian, March 12, 1969, p. 13.

- Fishing Extended," Oregon Journal, August 7, 1971, p. 2. 
- Fish Rights Aided," The Oregonian, December 23, 1970, p. 18. - Fish Rule Upheld," The Oregonian, April 18, 1970, p. 15. "Indians Free in Fish Case," The Oregonian, June 4, 1966, p. 1. - Rights Defined," The Oregonian, June 2, 1968, Sec. F, p. 2. - Jailed for Gillnetting in Defiance of State Law," The Oregonian, April 19, 1966, p. 13.

Lose Fishing Test, Jurors Convict Three Yakimas," The Oregonian, December 3, 1966, p. 8 .

- Oppose Plan to Repeal F1sh Pact," Oregon Journal, February 25, 1967 , p. 5.

- On Warpath to Preserve Fishing," The Oregonian, July 31, 1966, Sec. 3, p. 9 .

- Rights Upheld, Protection of Fishing Privileges Ordered, "The Oregonian, November 6,1931 , p. 2.

- Victors in Fishing Sult," The Oregonian, September 6, 1947, p. 1. - Win Injunction in Fish Case," Oregonian Journal, August 14, 1970, p. 6 .

"Injunction Filed for Indian Tribes," The Oregonian, April 17, 1947, p. 10. Jepsen, Don, "Fish Game Merger Advances," Oregon Journal, June 23, 1973, p. 1 .

- "House Votes F1sh, Game Merger OK," Oregon Journal, June 30, 1973, P. 5.

- "Sports Groups to Delay Fish-Game Vote," July 20, 1973, p. 3.

"Judge Removes Motions in Indian Litigation," The Oregonian, January 7, 1969 , p. 17.

- Rules Indians May Fish in 'Usual, Accustomed Places', Wi thout Arrest," Oregon Journal, August 1, 1968, p. 7.

- Solomon Refuses to Ban Indian Fishing At Three Mile Dam and Nearby Areas," The Oregonian, July 23, 1963, p. 9.

Kramer, Matt, "Senate Passes Steelhead Bill," Statesman, May 17, 1969, p. 6. (Microfilm).

"Legislative Report: Student Observers Are Fun," Hearld and News, April 17, 1969, p. 12. (Xerox copy). 
McCallister, Tom, "Little Bill Leaves Steelhead as Game Fish," Oregon Journal, March 12, 1969, p. 2. (Microfilm).

- "Meaningless Steelhead Bill Reaches Final Vote," Oregon Journal, May 16, 1969, p. 2. (Microfilm).

- Magner, James, "Judge Rules in Favor of 1855 Indian Flshing Treaty," The Oregonian, April 25, 1969, p. 19.

"Managing Fish For AIl," Oregon Journal, April 23, 1966, p. 8.

"More Arrests Vowed If Indians Net Salmon," Oregon Journal, April 19, 1966, p. 1 .

Newboy, Anthony, "Gas Bubbles Threaten Fish," The Oregonian, March 28, 1971 , p. 3. (Microfilm).

"Nitrogen Per1l Lifeline Tossed to Salmon, Trout," Atlanta Journal and Constitution, May 7, 1972, p. 20-B. (AP Portland Oregon).

"N. W. Steelheaders Go Gillnetting Catch No Steelhead," Columbia River Gillnetter, April, 1970, Vol. 2, No. 1, p. 1. (Microfilm).

"Olcott Signs B1ll Ending Fish Tangle," Oregon Journal, January 16, 1920, p. $I$.

"Oregon Answers Fish Claim," Oregon Journal, September 6, 1968, p. 3. - Fish, Game Agency Merger Approved by House," The Oregonian, January. 30, 1973, p. 16 . - Wants 3 Judges to Decide Fishing Case," The Oregonian, October 1, 1968, p. 14.

Rayner, Audrey, "Merger of Panels Could Hlep Resolve Fishing Arguments," The Oregonian, March 23, 1973, p. 36.

"Salem Report: Rushing Last Minutes," Hearld and News, May 14, 1969. (Xerox copy).

"Separate Plan of Fish, Game Control Pays," Oregon Journal, December 15, 1922 , p. 7.

"Seperation of Commercial and Game Board, Plan," Oregon Journal, December 21, 1919, p. 15.

"Senate to Vote Friday on Steelhead Measure," The Oregonian, May 16, 1969, p. 40. (Microfilm).

Seymour, Douglas, "New District New Problems," The Oregonian, October 26, 1972, p. 39. 
"The People's Own Corner," The Oregonian, September 17, 1962, p. 18. (Microfilm).

- The Oregonian, May 5, 1969, p. 26. (Microfilm).

- The Oregonian, June 26, 1972, p. 14. (Microfilm).

- The Oregonian, July 22, 1973, p. F.2.

"The People Speak," Oregon Journal, August 20, 1969, p. 12. (Microfilm). - Oregon Journal, August 23, 1969, p. 10. (Microfilm). ."

"Proposal Suggests Speed for Ruling on Steelhead," The Oregonian, August 11,1962 , p. 6. (Microfilm).

"Solons Assure Fish Game Merger Action - Salem," The Oregonian, July 20, 1973 , p. 37.

"Solon Reports Threats Over Stand on Steelhead," The Oregonian, April 24, 1969, p. 22. (Microfilm).

"Spence, Morton, House OKs Steelhead Compromise," Oregon Journal, May 6, 1969, p. 1. (Microfilm).

"Sportsmen After Warden's Scalp," Oregon Journal, March 18, 1919, p. 2. - Indulge in Heated Debate," The Oregonian, February 20, 1930, p. 3. - Object to Plan to Abolish Game Commission," Oregon Journal, January 24,1915, p. 9.

- Open Attack on Fish and Game Body," Portland Telegram, March 26, 1919 , p. 22.

- See Dorrís' Removal as War Opener," Oregon Journal, April 16, 1925 , p. 6.

- Will Carry Fight to People at Polls," Oregon Journal, March 25, 1919 , p. 15.

"State is Now Without Game or Fish Body," Portland Telegram, January 22, 1920 , P. 1 .

"Steelhead Bill Ruled off Ballot," Oregon Journal, July 31, 1962, p. 1. (Microfilm).

Bill Sent to the House," Oregon Journal, April 30, 1969, p. 1. (Microfilm).

- Catch Reduced," Oregon Journal, March 18, 1970, p. 15. (Microfilm). 
Fishing in Columbia to Continue Under Present Plan," The Oregonian, March 2, 1968, p. 9. (Microfilm).

"Strong Dissent," The Oregonian, May 20, 1969, p. 3. (Microfilm).

"Some People Say Yes and Others Answer No," The Oregonian, August 26, 1942, p. 8. (Microfilm).

Tippens, Jerry, "Commission Ready to Crack Down on Indians Who Violate State Fishing Laws," Oregon Journal, January 6, 1966, p. 3.

"Unified Commissions on Fish, Game Urged," The Oregonian, December 10 , 1970 , p. 15.

"U. S. Backs Fish Rights for Indians," Oregon Journal, September 13, 1968, p. 1.

"Vote No on 非 15 and Keep Steelhead a Game Fish," The Oregonian, November 3, 1974, p. A-20. (Advertisement).

- Title Revamped," Oregon Journal, April 19, 1962, p. 1. (Microf $(1 \mathrm{~m})$.

"Waltonians Fight Consolidation of Game Commission," The Oregonian, January 10,1935, p. 2 .

"Washington Steelhead Claim Denied at Meet," Oregon Journal, April 14, 1957, p. 3. (Microfilm).

"Wildlife Expert Pushes Merger of Fish, Game Commissions," The Oregonian, July 30, 1964, p. 22.

"Will Your Vote Make Hirohito Happy?" The Oregonlan, November 2, 1942, p. 5. (Advertisement) (Microfilm).

"Yakima Tribe, Asks Court Order," The Oregonian, March 18, 1966, p. 33.

Yocom, Doug, "Few Issues Settled on Indian Fishing," Oregon Journal, April 10, 1969, p. 3 .

- and Jepsen, Don, "F1sh Game Merger Scrap Keeps Legislature in Session," Oregon Journal, July 6, 1973, p. 1.

- "Interior's Fish Law Proposal Challenged;" Oregon Journal, January 28,1969 , p. 2 . 